Review

\title{
Cellular Targeting of Oligonucleotides by Conjugation with Small Molecules
}

\author{
Manuel Hawner and Christian Ducho * \\ Department of Pharmacy, Pharmaceutical and Medicinal Chemistry, Saarland University, Campus C2 3, \\ 66123 Saarbrücken, Germany; manuel.hawner@uni-saarland.de \\ * Correspondence: christian.ducho@uni-saarland.de; Tel.: +49-(0)681-302-70343 \\ Academic Editor: Katherine Seley-Radtke \\ Received: 22 November 2020; Accepted: 11 December 2020; Published: 16 December 2020

\begin{abstract}
Drug candidates derived from oligonucleotides $(\mathrm{ON})$ are receiving increased attention that is supported by the clinical approval of several ON drugs. Such therapeutic ON are designed to alter the expression levels of specific disease-related proteins, e.g., by displaying antigene, antisense, and RNA interference mechanisms. However, the high polarity of the polyanionic ON and their relatively rapid nuclease-mediated cleavage represent two major pharmacokinetic hurdles for their application in vivo. This has led to a range of non-natural modifications of $\mathrm{ON}$ structures that are routinely applied in the design of therapeutic $\mathrm{ON}$. The polyanionic architecture of $\mathrm{ON}$ often hampers their penetration of target cells or tissues, and ON usually show no inherent specificity for certain cell types. These limitations can be overcome by conjugation of $\mathrm{ON}$ with molecular entities mediating cellular 'targeting', i.e., enhanced accumulation at and/or penetration of a specific cell type. In this context, the use of small molecules as targeting units appears particularly attractive and promising. This review provides an overview of advances in the emerging field of cellular targeting of ON via their conjugation with small-molecule targeting structures.
\end{abstract}

Keywords: oligonucleotides; conjugation; small molecules; cellular targeting

\section{Introduction}

\subsection{Principle Biological Mechanisms of Oligonucleotide Action}

The earliest steps to address genetic disorders or infections at the genetic level have been made with so-called antisense oligonucleotides (ASO) (Figure 1). The potential to exploit exogenous deoxyribonucleic acids for the purpose of medical treatment were discovered by Zamecnik and Stephenson in association with Rous Sarcoma Virus [1], where single strand (ss) DNA was applied to form a DNA/RNA heteroduplex with a complementary viral RNA via Watson-Crick base pairing [2]. In general, the emergence of any irregular biological activity $[3,4]$ is often related to a homeostatic imbalance of genes [5] or proteins [6] within cells or tissues. Targeting mRNA as the fundamental blueprint and source of pathology therefore represents an attractive option for restoring balance and decommissioning the expression of defective and dilapidated genes or their protein products. In general, a synthetic oligonucleotide $(\mathrm{ON})$ can induce its action in two different cell compartments: the cytoplasm and the nucleus [7]. Interferences with genetic material in the nucleus are summarized under the collective term 'antigene' and are beyond the scope of this review $[8,9]$. However, antisense action takes place in the cytoplasm where ASO compromise translation of mRNA via two common pathways [10]. On the one hand, the tailor-made sequence binds to its ribonucleic counterpart causing simple translational arrest due to steric hindrance at the ribosomes' binding site or by prohibiting ribosomal motion along the mRNA [11]. On the other hand, the ASO might recruit the endonuclease RNase $\mathrm{H}$ that 
selectively recognizes RNA in DNA/RNA heteroduplexes and degrades the RNA strand [12]. Because of this inherent feature of RNases [13], ASO are only required in small 'catalytic' amounts, which helps with several pharmacokinetic obstacles to ON delivery that are described in the following sections. ASO are nowadays often designed as chimeric gapmers, which have deoxyribonucleotides in the center flanked by several modified nucleotides to prevent unwanted degradation by exonucleases [14-16]. They often also possess a phosphorothioate backbone further enhancing serum stability as the sulfur-containing modification impedes nuclease activity $[17,18]$. Phosphorothioate ON exhibit an enhanced binding to serum proteins [19], which is why such ON are preferably taken up by the liver [20,21]. Two known FDA-approved representatives of this type are Fomivirsen [22] (against cytomegalovirus retinitis, the first FDA-approved ASO drug) and Mipomersen [23] (against familial hypercholesterolemia).

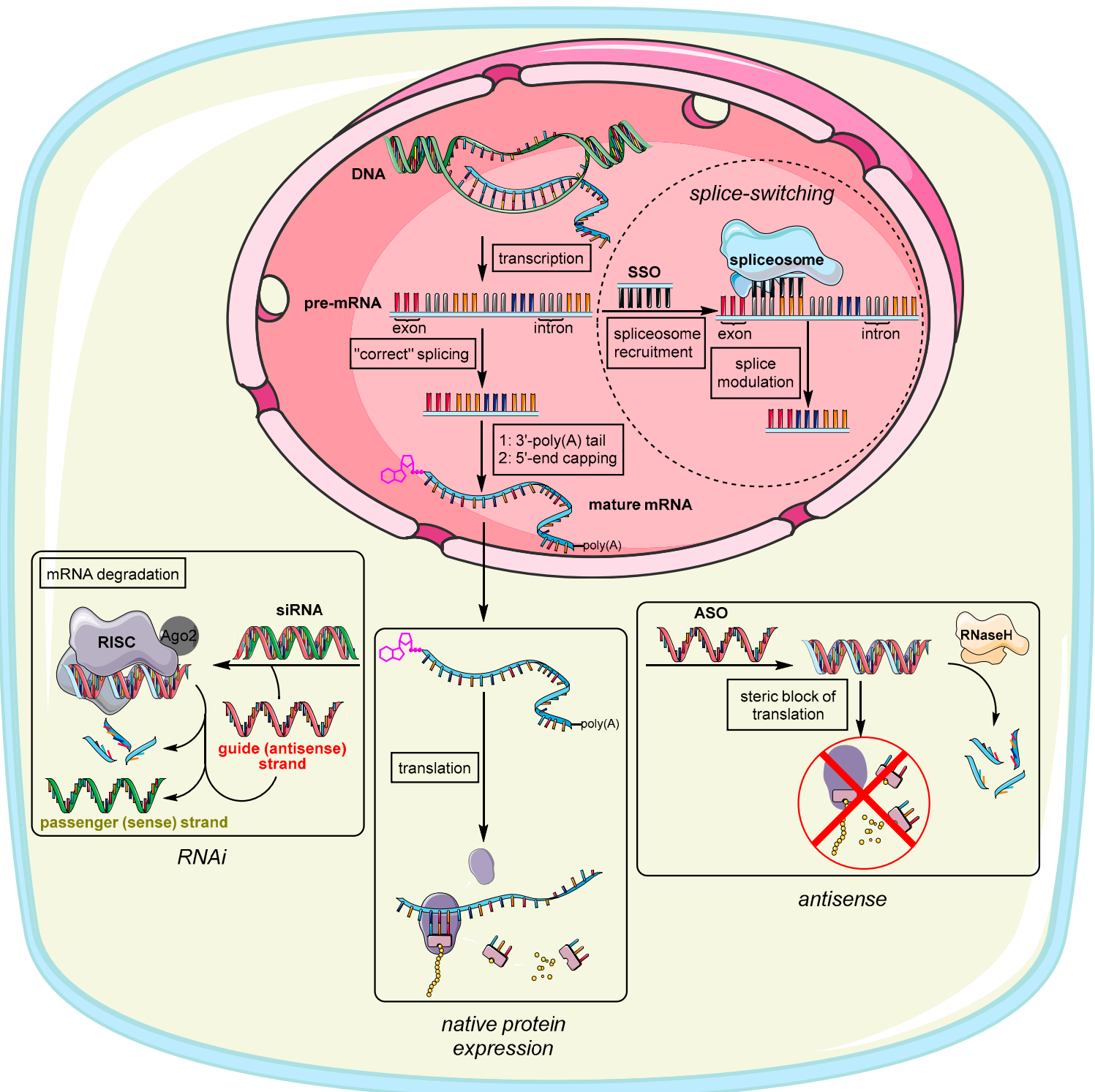

Figure 1. Principle modes of action of therapeutic $\mathrm{ON}$ in the nucleus and the cytosol in relation to native (i.e., unaltered) protein expression. This figure uses graphical templates from Servier Medical Art, licensed under a Creative Common Attribution 3.0 Generic License. http://smart.servier.com/.

Splice-switching ON (SSO) are a variation of ASO that interact with nuclear pre-mRNA during the splicing process, thus altering exon inclusion, exclusion, or choice in general (Figure 1) [24]. $\mathrm{SSO}$ are usually administered to treat genetic disorders, which are consequences of genetic mutations 
within these exons [25]. For this reason, there are many starting points for SSO to literally splice out defective genes. Exons in general are the coding sections of genes interspersed with introns, i.e., non-coding sequences within the pre-mRNA transcript [26]. During the splicing process, the exons containing the transcript for proteins are fused together by the spliceosome, thus leaving out the introns [27]. The spliceosome therefore has to bind to specific splicing sites, by which the order of exon combination can also be altered (alternative splicing) [28]. This offers two options to restore correct splicing. First, an exogenous ASO is designed to base-pair to a (non-natural) splicing enhancer sequence [29] created through mutation [30]. Blocking this site causes the machinery to skip this exon leaving out genetic disinformation. Second, an ASO can be designed to base-pair with a splicing silencer sequence. This prevents binding of a negatively acting splicing protein, ultimately causing inclusion of original exons that were skipped before (through mutation) [31]. Approved SSO therapeutics are Nusinersen [32,33] for the treatment of spinal muscular atrophy, Golodirsen [34,35] and Eteplirsen [36,37] to treat Duchenne muscular dystrophy, and Milasen [38], a pioneering example of personalized medicine to treat Mila Makovec's form of batten disease.

The discovery of RNA interference (RNAi) as a fundamental endogenous mechanism for controlling gene expression further broadened the potential of therapeutic $\mathrm{ON}$ and served as a boost in the development of new ON structures [39]. In RNAi, small non-coding double-stranded (ds) RNA (usually 20-25 nucleotides long) targets mature mRNA in the cytosol to prevent the expression of specific proteins by mediating the degradation of mRNA (Figure 1) [40]. The original physiological functions of RNAi are widespread, e.g., degradation of exogenous viral RNA [41] or regulation of endogenous gene expression. These processes are mediated by endogenous versions of the aforementioned dsRNA usually referred to as microRNA (miRNA) [42]. To achieve miRNA-mediated RNAi, long dsRNA is cleaved by dicer proteins to generate shorter dsRNA fragments consisting of a sense (passenger) and antisense (guide) strand. The latter of these two strands is complementary to the target mRNA sequence that is supposed to be degraded. This step is necessary to prevent interferon-mediated immune response [43]. The guide strand and the target mRNA are recognized by ribonucleoprotein complexes named RNA-induced silencing complexes (RISC) [44]. During the formation of RISC, endonucleases known as Argonaut proteins (Ago2) separate the guide (antisense) strand from its passenger (sense) strand, thus only loading the guide strand into the RISC [45]. Artificial exogenous versions of mature miRNA are usually referred to as small interfering RNA (siRNA). For siRNA to get Ago2 to choose the 'correct' strand as guide strand, non-canonical modifications are imbedded in the backbone of the passenger (sense) strand that are not compatible with the RISC machinery [46]. Ultimately, the preferred incorporation of the desired (guide) strand into the RISC can be steered by two factors. First, lowering duplex stability simplifies strand separation by Ago2. Second, pronounced chemical modifications of one strand can hamper its incorporation because it does not meet the structural requirements of the RISC [46,47]. RNA exhibiting an A-form helical topology is generally preferred for entering the RISC [47]. Finally, the targeted mRNA that is complementary to the guide strand is cleaved between nucleotides 10-11 (counted from the $5^{\prime}$-end) [48]. This therefore represents an adequate binding site for modifications and targeting ligands, further enhancing strand separation and altering the silencing of protein expression [49,50]. This is demonstrated in several examples [51-56]. A prominent representative of RNAi-triggering therapeutics is the first FDA-approved siRNA drug Patisiran $[57,58]$ against hereditary transthyretin-mediated amyloidosis. Another promising candidate in a phase III clinical trial is Inclisiran $[59,60]$ (for the treatment of familial hypercholesterolemia). Very recently, the FDA [61] as well as the European Medicines Agency [62] have approved Lumasiran as a novel RNAi drug that will be used for the treatment of primary hyperoxaluria type 1 (PH1). This 'orphan status' conjugate consists of an siRNA that targets hydroxy acid oxidase 1 (HAO1) mRNA and that is covalently bound to a ligand containing three $N$-acetylgalactosamine (GalNAc) units for improved delivery [63]. The presence of a defective variant of HAO1 leads to nephrocalcinosis and calcium oxalate crystal deposition in the urinary tract, which causes kidney damage and urinary tract 
infections and, in the worst case, may thus require an organ transplant [64,65]. More siRNA drug candidates that are currently in clinical trials have been reviewed by Song et al. [66].

\subsection{Chemically Modified $O N$}

Despite the tremendous potential that ASO, SSO, siRNA and other ON-based therapeutics $[7,67]$ exhibit in vitro, they are subject to a range of hurdles in vivo. These are mainly related to distribution, metabolism and toxicity [68]. For instance, synthetic oligonucleotides are potential substrates for exoand endonucleases, leading to short half-lives in vivo [69]. Their native polyanionic structure results in poor uptake into target cells or tissues [70]. Extracellular degradation in blood and tissue, intracellular degradation in the reticuloendothelial system (RES) as well as loss of ON by rapid renal excretion further limit their therapeutic potency in vivo and can ultimately lead to their ineffectiveness [71]. To overcome these hurdles, a plethora of structural modifications have been established and are summarized below.

The chemical 'toolbox' available for ON modifications (Figure 2) can be divided into four sections: (i) modifications of nucleobases; (ii) modifications of internucleoside linkages; (iii) modifications or replacements of the ribose unit; and (iv) alternative backbone structures. Generally speaking, each modification has an underlying rationale and causes improvement to at least one of the aforementioned issues. Depending on their difference to native ON structures and time of publication, several modifications are also grouped in 'generations' ranging from first to third.

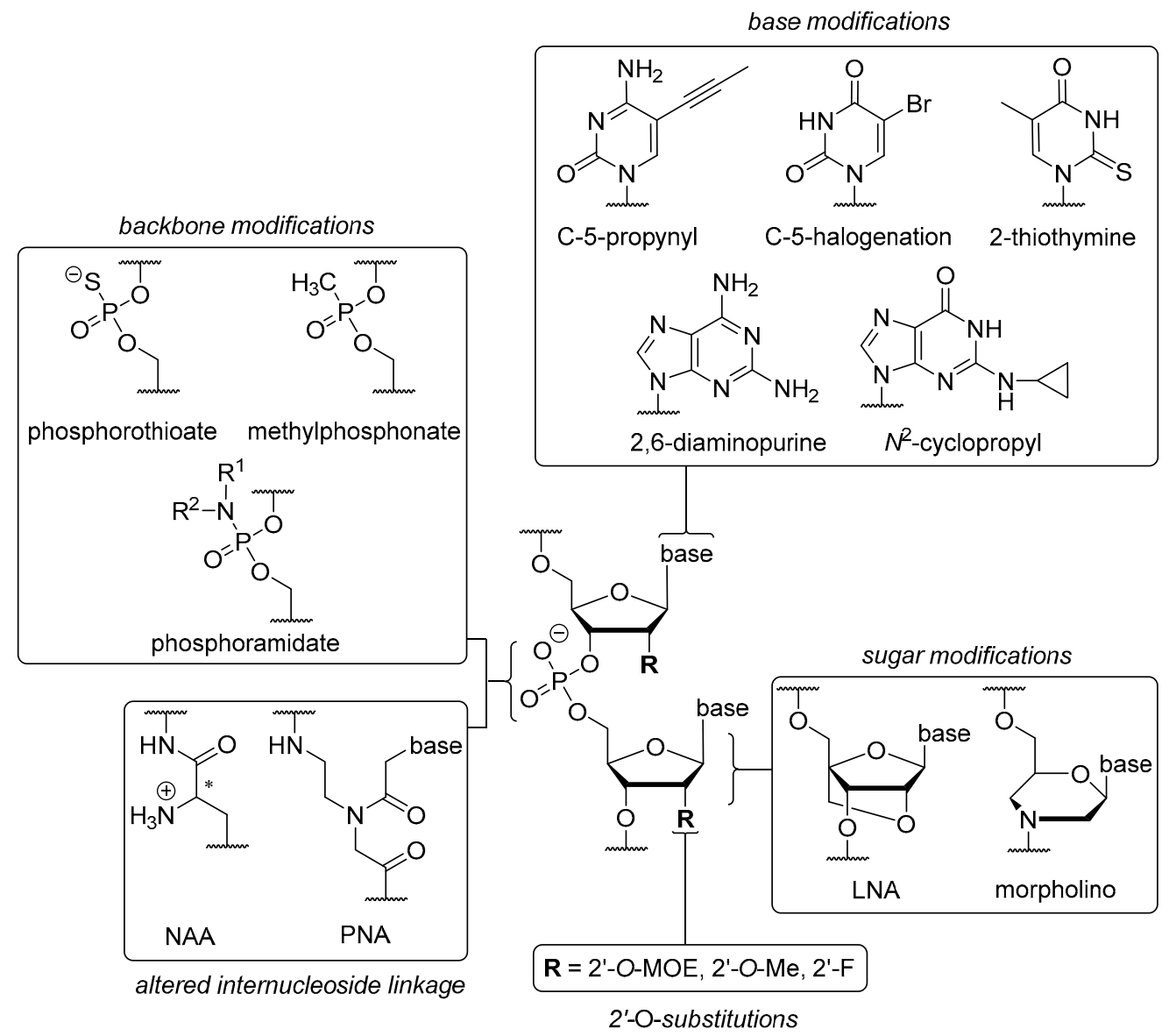

Figure 2. Some selected structural modifications of therapeutic ON with respect to their site of implementation.

A modification that is indispensable and has been employed in the structures of Fomivirsen and Mipomersen is the phosphorothioate (PS) backbone (Figure 2). The introduction of non-bridging sulfur 
at the phosphate unit furnishes a novel stereogenic center at the phosphorus atom [72], resulting in diastereomers with either $\left(S_{\mathrm{P}}\right)$ or $\left(R_{\mathrm{P}}\right)$ configurations. These show different properties in terms of nuclease stability and binding affinity to the complementary (target) strand $[17,18]$. The 'stickiness' of sulfur further enables binding to plasma proteins such as albumin [73] or other biopolymers like heparin [74]. As a result, it leads to prolonged plasma half-lives [75] and reduced renal excretion. For PS backbones in ON, one has to consider possible toxic side effects though [76]. Together with the electroneutral methylphosphonate modification [77], the PS backbone belongs to the group of so-called 'first generation' modifications. Increased nuclease stability can also be achieved via electronic properties contrary to native $\mathrm{ON}$ structures, for instance by introducing positively charged nucleoside analogues [8,78] to create partially zwitterionic backbone structures [79-81]. A site-specific introduction of such cationic nucleosyl amino acid (NAA)-modifications enhances the stability of the resultant partially zwitterionic ON towards $3^{\prime}$ - and $5^{\prime}$-exonucleases and in more complex biological media (human plasma, human cell lysates).

'Second generation' modifications are briefly discussed below. However, quite extraordinary backbone structures can be found in the 'third generation', e.g., phosphorodiamidate morpholinos (PMO) [77] and peptide nucleic acids (PNA, Figure 2) [82,83]. PMO have a six-membered morpholine ring replacing the ribose unit, thus leading to an $\mathrm{N}^{\prime} \rightarrow \mathrm{P}^{\prime}$ internucleoside linkage and an electroneutral $\mathrm{P}-\mathrm{N}$ bond (hence a diamidate). The latter carries lipophilic alkyl chains for enhanced membrane permeability and replaces the anionic oxygen of the native phosphate diester. Due to their significant structural differences to native ON, PMO are not able to trigger RNA degradation via RNase $\mathrm{H}$ or RNAi [84]. However, they are successfully used to block RNA interactions or further RNA processing in many ways [85], e.g., splicing of pre-mRNA in the nucleus [86]. The unnatural structure of PMO also causes high nucleolytic stability [87] and prevents toxic side effects correlated with administration [88]. In PMO and PNA backbones, both the ribose unit and the internucleoside linkage are altered. In contrast, locked nucleic acids (LNA, third generation) are considered as sole ribose modification and are characterized by the rigid $3^{\prime}$-endo (North, $\mathrm{N}$ ) conformation in which a methylene group bridges the 2'-O-substituent and the C-4' position [89], hence leading to a gauche conformation [90]. This rigidified sugar structure has been proven to enhance duplex stability [91] when hybridized with other LNA, DNA, and RNA strands [92,93]. Furthermore, LNA shows enhanced stability against exonuclease degradation when introduced at the $5^{\prime}$-end [94] or the $3^{\prime}$-end [15], thus displaying a key property for successful drug delivery. LNA are often used in so-called 'gapmer' structures. In gapmer ON, LNA-modified ends flank a less modified (e.g., PS) central 'gap' segment, hence furnishing enhanced nuclease stability with retention of RNase $\mathrm{H}$ activation [14].

Some notable 'second generation' modifications are placed in the 2'-position of the ribose ring, e.g., (i) $O$-alkylations such as 2'-O-methyl (2'-OMe), a naturally occurring RNA sugar modification [95] and (ii) artificial 2'-O-methoxyethyl (2'-MOE) moieties (Figure 2) [96]. Both of these modifications are commonly implemented in the design of ASO gapmers. Due to stereoelectronic effects, they are not suitable to promote RNase $\mathrm{H}$ activation [97]. However, the same properties as well as the electron-withdrawing oxygen atom also contribute to an N-type/gauche conformation [98]. Hence, the formation of an A-helix is promoted [99] that shows increased nuclease stability [100] due to elevated melting temperatures [101] and bound water molecules in the minor groove (2'-MOE) [98]. Placing a fluorine atom at the 2 '-position affords unique properties for RNAi. 2'-Fluoro-RNA does not cause immunostimulatory effects [102]. As a result of the polarized C-F bond and the absence of H-bond interactions in the minor groove, the $2^{\prime}$-fluoro modification leads to an augmented enthalpy [103] causing stronger Watson-Crick base-pairing [104] that ultimately results in more stable duplex formation [105]. It also furnishes significantly improved nuclease stability [106] resulting from a preferred $3^{\prime}$-endo (North) conformation.

The overall goal of structural changes to the nucleobases usually is an improvement of both pharmacodynamics and pharmacokinetics, i.e., enhanced duplex stability and target specificity, nuclease stability, and improved cellular uptake. These goals have to be met with retained Watson-Crick base 
pairing fidelity. However, impact of the modified bases depends both on the choice of its placement in the guide or passenger strand of siRNA [107] and within a strand (i.e., modifications at the $5^{\prime}$-end or $3^{\prime}$-end) [108]. Thus, improvements in one property can be linked to a deterioration in another one. Possibilities for structural changes to the nucleobases are numerous as summarized, for instance, by Herdewijn et al. [109] and Peacock et al. [110]. Hence, only a few selected examples are briefly mentioned here [111-114].

In the case of pyrimidine bases, structural alterations of the scaffold can be made at four positions, i.e., at C-2, C-4, C-5, and C-6. Variations at the C-5-position represent a favorable option for improved RNAi activity and duplex stability. Such C-5-variations can be, for example, halogenated derivatives such as 5-bromouracil (U[5Br]) and 5-iodouracil (U[5I], Figure 2) that are capable of tautomerism [115] due to their acidified $N^{3}$-hydrogen. The original aim was to strengthen H-bonding and improve base stacking. Unfortunately, different base-pairing properties were found to be possible depending on whether the keto or enol tautomer is present. This, in turn, depended on the $\mathrm{pH}$ of the environment [116]. The keto tautomer is able to base-pair with adenine (Watson-Crick type), stabilizing A-U H-bonding relative to unmodified $U$, giving decreased RNAi activity [115]. The enol tautomer is able to mimic cytosine and thus pairs with guanine. This leads to point mutations and unfavorable mismatches [117]. Replacing the methyl group in thymine did not show any advantage [118], so C-5 halogenations seem to have no decisive benefit. C-5-alkyl cytosine analogues, in particular naturally occurring C-5-methyl derivatives, proved to increase melting temperatures by $0.5{ }^{\circ} \mathrm{C}$ per modification [119]. This feature originates from hydrophobic methyl stacking between the planar nucleobases in the major groove. The modification also reduces immunostimulation and retains nuclease stability [111]. C-5-methyl derivatives of uracil and cytosine lead to retained or improved silencing activities, depending on their site of implementation [120]. Unfortunately, they are prone to deamination in acidic environment [121]. The incorporation of 5-ethyl cytosine led to less stable duplexes with reduced affinity compared to 5-methyl and native cytosine [122] as well as to a reversible and fast transition between B- and Z-helices. However, C-5-propynyl derivatives of uracil and cytosine afforded enhanced cell permeability and duplex formation in ASO [123] due to the alkyne unit stacking in the major groove. On the other hand, this modification reduced RNAi activity when placed at the guide strand's $5^{\prime}$-end [120]. Contrary results alongside good base-pairing fidelity were achieved for placement of the modification within this strand [124]. Improved duplex stability and RNase $\mathrm{H}$ activation were shown for C-5-heteroaryl substituents such as thiazole, pyridine, thiophene, and imidazole. These showed coplanar orientation with the pyrimidine moiety and thus base stacking with neighboring adenine [125]. Unaffected H-bonding in the major groove is a general requirement for effective RNAi $[115,120]$. The introduction of 2-thiothymine within the gap region caused RNase H-mediated cleavage at an altered position within the mRNA strand. This correlated with a steric clash with some amino acids in the active site [126]. Furthermore, the highly polarizable sulfur atom stabilized the $3^{\prime}$-endo conformation [127] leading to stronger H-bonding [128] due to an increased acidity of the 3-NH [129].

In the case of purine bases, the main alterations are introduced at nitrogen atoms in positions 1, 3, and 7, respectively, in addition to C-2, C-6, and C-8. For example, 2,6-diaminopurine (DAP), an adenine analogue with an additional amino group at C-2 (Figure 2), exhibits stronger base-pairing with $\mathrm{T}$ due to the formation of three (instead of two) H-bonds, thus overcoming the relative weakness of A-T base-pairing $[130,131]$. Melting temperatures were increased by $1.5^{\circ} \mathrm{C}$ per modification when DAP base-paired with both DNA or RNA [132]. For the incorporation of DAP in ASO, one has to consider that it is prone to depurination under acidic conditions during DMTr-cleavage in ON synthesis. An additional introduction of an $N^{2}$-imidazolylpropyl moiety in DAP strongly enhanced duplex stability without impeding RNase $\mathrm{H}$ activation at several positions within an ASO strand due to interactions with the phosphate backbone in the minor groove [133]. Replacing the N-7 in adenine by a propynyl group led to increased stability at the expense of reduced activity. An according guanine analogue showed enhancement considering both features [134]. Reduced immunostimulation was 
found for $N^{2}$-cyclopropyl and $N_{2}$-propyl modifications, along with retained silencing effects [135]. For this, several positions for an optimal placement in the guide and passenger strands of siRNA were evaluated. $N^{2}$-imidazolylpropyl [133] and $N^{2}$-aminopropyl derivatives of guanine [136] afforded strongly improved thermal stabilities and retained RNase $\mathrm{H}$ activation when placed in DNA or RNA, due to interactions with the phosphate backbone of the counterstrand.

\subsection{Endocytotic Pathways}

Cells have several pathways for the internalization of large 'biologics', e.g., clathrin-coated pits, caveolar pathways (lipid rafts with high contents of sphingomyelins, glycosphingolipids, and cholesterol [137]), pinocytosis and phagocytosis [138,139]. However, the interim destination of the thus transported molecules is the same for all endocytic mechanisms: early endosomes (EE). EE are slightly acidic [140], spherical lipid vesicles in which compounds are loaded and sorted [141] for the purpose of transport [142]. Thus, EE can be interpreted as 'shuttles' needed for ON to enter cells. The route that transports materials to the trans Golgi network (TGN) is also operated by EE [143]. Once loaded, vesicles from the plasma membrane containing both the $\mathrm{ON}$ and an uptake-mediating receptor are translocated to EE. From EE, transport continues towards late endosomes (LE) [144] into which the cargo is reloaded via invading intraluminal vesicles (ILV) [145]. At this stage, LE containing several ILV are commonly referred to as multivesicular bodies (MVB) [144]. Furthermore, EE are also able to mature directly to LE [142] pointing out that EE can transfer cargo via a dual mechanism [146]. Beyond that, Clathrin-dependent cargos have the ability to recycle back to the cell surface via recycling endosomes (RE) [147]. Candidates for immediate return to the plasma membrane are LDL receptors [148], transferrin [149], and the asialoglycoprotein receptor (ASGP-R) [150]. LE ultimately fuse with lysosomes (LY) [151], the primary digestion apparatus of the cell containing degrading enzymes at low $\mathrm{pH}$. Here, $\mathrm{ON}$ are ultimately degraded if they have not 'escaped'. Every point of transfer along this line therefore represents an opportunity for $\mathrm{ON}$ to escape to the cytoplasm, where they can unleash their biological activity [152]. In general, the biological action of ASO, SSO, and siRNA correlates with the endocytotic pathway by which they are taken up [153]. siRNA are usually transfected with carriers, e.g., cationic polymers (PP) or polymer nanoparticles (LNP). ASO and $\mathrm{SSO}$, respectively, benefit from their (often employed) PS backbone. However, the release of ON from MVB and/or LE appears to be the crucial endogenous process for attaining pharmacological effects [139].

Regarding the distrubution and cellular uptake of native ON, insufficient delivery is an intrinsic issue due to the lack of structural units that could mediate interactions with cell surfaces or plasma proteins. However, PS-modified ON show a boost in cell penetration via clathrin-dependent pathways as they directly bind to cell surface receptors (stabilin [21], scavenger receptors [154]) or interact with a vast number of proteins [155] such as annexin A2, thus additionally enhancing ASO activity. Once taken up, they can be transported from EE to LE and LY [156]. The release of such therapeutic ON usually occurs from LE [157] via back fusion processes in which lysobisphosphatidic acid (LBPA)-rich ILV are suggested to be bound to the LE membranes [158,159], as it is discussed in more detail below.

Apart from non-conjugated therapeutic $\mathrm{ON}$, whose cellular uptake is commonly referred to as 'gymnosis', ON therapeutics are often administered with additives. For siRNA, most of the early approaches in this direction were based on the formation of large aggregates, e.g., lipid and synthetic nanoparticles, rather than on structurally modified siRNA with defined molecular composition. For instance, siRNA embedded in neutral LNP has been shown to mainly enter the endosome via macropinocytosis and break free from a hybrid EE/LE before being translocated to LE or LY [160]. siRNA wrapped in cationic LNP also uses micropinocytosis for cell entry and is then delivered to LE and LY [161]. A crucial finding was the key role of the recycling machinery for all sorts of endosomes regarding intracellular delivery. Herein, the cholesterol transport protein NPC1 proved to be involved in the return transport of the internalized ON from LE to the plasma membrane, ultimately lowering the intracellular availability of ON for sufficient biological effects [162]. The uptake of polyplexes 
of siRNA and cell-penetrating peptides (CPP) as well as of siRNA-CPP conjugates was found to be dependent on scavenger receptors (SCARA) being involved in receptor-mediated endocytosis [163]. Similar observations were made with an SSO, for which clathrin-mediated uptake was responsible for internalization of SSO-CPP polyplexes [164]. Differences were found for the release modalities of an ASO targeting human tyrosine-protein kinase (src) [165] when transfected either as a lipoplex or as a polyplex [166]. The formulation as lipoplex showed a more gradual release from endosomes due to a proposed pore-forming mechanism rather than a fusion process with the endosomal membrane [167]. The polyplex formulation caused an instantaneous release ('burst') after internalization owing to a proton-sponge effect, indicating that LE with their inherently lower $\mathrm{pH}$ might be the likely sites of escape $[140,168]$. Spherical nucleic acids (SNA) offer another design opportunity for the delivery of siRNA or ASO via their attachment to nanoscale metal particles, e.g., gold or quantum dots (QD) such as CdSe/ZnS 630 [169]. Studies in C166 mouse endothelial cells revealed caveolar uptake [170]. Final accumulation of such particles in LE was observed, and degradation took place with release of the ON fragments to the cytosol and retention of the core structures inside the endosomes [171]. Recent work showed that the uptake of SNA via clathrin-mediated endocytosis is possible [172] when the class A macrophage scavenger receptor (SR-A) is addressed [173].

Overall, all the aforementioned approaches have in common though that they require vast amounts of additives, thus lowering the drug-load capacity and increasing the risk of adverse side effects. Therefore, the modulation of endocytic pathways towards a uniform uptake mechanism (e.g., receptor-mediated uptake) could improve the biological activity of all types of ON-based therapeutics by turning off the plethora of different uptake mechanisms that (at least partially) contribute to the intracellular endosomal arrest of $\mathrm{ON}$. The conjugation of $\mathrm{ON}$ with suitable small molecules can be a way to address cell-specific surface receptors that are mainly internalized via clathrin-mediated processes $[174,175]$, thus enabling a unified uptake pathway ('self-delivery') without the use of potentially toxic transfecting agents. For instance, SSO conjugated with an RGD peptide induced receptor-mediated uptake via interaction with integrins, were transported to LE and exhibited a slow, gymnosis-like intracellular release pattern [176]. An siRNA-cholesterol conjugate was found to be internalized via binding to epidermal growth factor at the membrane and to be transported via a specific form of EE having the early endosome antigen 1 (EEA1) [177], a protein required for fusion processes with LE [178].

With respect to endosomal release, it is known that ASO accumulate in late endosomes and that the release of a tiny amount of them [179] enables the downregulation of target mRNA [159,180,181]. However, any form of exogeneous ON have to encounter the complex maze of intracellular pathways as outlined above, thus leading to a variety of intracellular destinations. Upon receptor binding, the ligand-receptor complex begins to constrict in a vesicle, being squeezed out of the plasma membrane with the help of the GTPase dynamin [174] that tightens its spiral structure around the neck of the budding vesicle until the membrane is torn [182]. Initial uptake is then followed by traffic to a number of low $\mathrm{pH}$ endomembrane compartments as mentioned above, namely EE, RE, LE, LY, and MVB, but also the TGN and the endoplasmic reticulum (ER) [183]. This trafficking is regulated by other GTPases, the Ras-related in brain ( $\mathrm{Rab}$ ) protein family that is also responsible for cargo selection, promotion of vesicle movement and initiation of fusion processes with target compartments [183,184]. Herein, Rab5 is associated with the movement of clathrin-coated vesicles to the early endosome, Rab9 with traffic from LE to the Golgi apparatus. Subsequently, Rab proteins interact with tethering proteins [185] that mediate recognition of the new vesicles and direct them to the intended destination, e.g., specific Golgi sub-compartments [186], where binding of vesicle membrane-bound v-SNARE (soluble $N$-ethylmaleimide-sensitive factor attachment receptor) to target membrane-bound t-SNARE finally initiates the membrane fusion of cell compartments $[187,188]$. At this point, inhibition of protein kinase A with several small molecules [189] can prevent trafficking to LY as reaching the Golgi apparatus instead is a key interim step for endosomal escape of ON by intervention of the mannose-6-phosphate receptor (M6PR) [190]. With respect to potential sites for endosomal escape, 
three routes of vesicle traffic appear to be promising: (i) from RE to the plasma membrane; (ii) from EE to the Golgi apparatus, also known as the retrograde pathway [191]; and (iii) during formation of ILV within MVB, because the hot spots for fusion processes and vesicle budding are situated there and lipid bilayer disruptions are likely to occur at this stage [192]. In case of the latter, LBPA and specific multiprotein complexes (endosomal sorting complexes required for transport, ESCRT) appear to play important roles in the release of intraluminal ON to the cytosol [193]. Herein, ESCRT III promotes the invagination of a membrane bud in the endosome [194] and carries out vesicle biogenesis for entering as well as mediating back fusion [195] together with LBPA [196]. At this point, intermediate non-bilayers are formed, ultimately leading to ON leakage due to strong membrane bending [197] and inner membrane strain of the small ILV [198].

Taken together, the aforementioned findings strongly support efforts to optimize the efficacy of AON or siRNA therapeutics via modulation of their pathways for cellular uptake and intracellular trafficking. The conjugation of $\mathrm{ON}$ with cell-targeting small molecules is an innovative approach to achieve at least some of these ultimate goals in the field of therapeutic ON. This review is intended to explore this promising strategy in more detail and to provide an overview of its state-of-the-art.

\section{Cellular Uptake of ON-Small Molecule Conjugates via Receptor Interactions}

Some of the major hurdles for the development of highly potent $\mathrm{ON}$ therapeutics are poor cellular uptake and the absence of cell specificity. Furthermore, potentially toxic transfecting agents also are a considerable issue of current strategies for ON delivery. Receptor-mediated endocytosis triggered by small molecule (SM) targeting units (i.e., receptor ligands) offers a promising way to overcome these limitations. For the design of such systems, suitable ligand-receptor pairs have to be evaluated with respect to (i) high affinity of the ligand for the specific receptor; (ii) differences in the expression pattern of the receptor in targeted cell types; (iii) receptor abundance; and (iv) receptor cycling between the plasma membrane and endosomal compartments. This principle understanding of receptor biochemistry is essential for the construction of a potent ON-SM conjugate.

\subsection{Anisamide Conjugates}

Anisamide is a high-affinity ligand of sigma-receptors $\left(\sigma_{1}\right.$ and $\left.\sigma_{2}\right)$ that are found at the endoplasmic reticulum and as transmembrane proteins [199]. These are well-known membrane proteins with neuro-modulatory and ion-channeling roles [200]. They show high affinity for psychostimulants [201] such as cocaine and methamphetamine $\left(\sigma_{1}\right)$ or benzamides such as anisamide [202]. Due to overexpression of these receptors in several types of cancer [203], e.g., breast [204], malignant melanoma [205], prostate [206], and lung [207,208], an exploitation of this ligand-receptor system for therapeutic purposes appears to be a promising strategy. Besides some according $\sigma_{1}$-ligands that are used as radioimaging agents in diagnostics [202], there are only few examples of anisamide being used for sigma-receptor targeting within the context of delivering therapeutic ON conjugates. In pioneering work, Huang et al. [206] improved the delivery of the widely used chemotherapeutic agent doxorubicin (DOX) using liposomes composed of a phospholipid and cholesterol that contained phosphatidylethanolamine-anchored anisamide. This formulation led to significant tumor growth inhibition in DU-145 cells (prostate) due to inhibition of topoisomerase II by encapsulated DOX as shown by competitive inhibition of sigma-receptors with haloperidol. However, patients would need to be treated with a significant amount of delivery-mediating agents causing toxicological issues [199,209] besides the poor drug-loading capacity [210,211]. Further work by Huang et al. [208] reports the delivery of ASO and siRNA using LPD (liposome-polycationic peptide-DNA) particles containing phosphatidylethanolamine-anchored anisamide into NCL-H1299 cells (lung). The transfected ON or siRNA, respectively, furnished mRNA downregulation of survivin, a member of the IAP-protein family inhibiting apoptosis [212]. This ON-mediated knockout of survivin prompted dysregulation of mitotic spindle checkpoints as well as defects in microtubule assembly and function that ultimately led 
to mitotic catastrophe of the studied cancer cells [213]. However, a set of transfecting agents had to be used here again to achieve the desired effect.

In contrast to these approaches, simple direct conjugation of anisamide to the therapeutic ON leaving out delivery agents can accomplish this goal as well and afford even better results without the aforementioned toxicological concerns. Juliano et al. constructed mono- and multivalent conjugates of anisamide attached to the 5'-end of a 3'-TAMRA-labelled 20-mer PS ASO (2'-O-methyl-RNA) [214] targeting a luciferase reporter gene by splice-switching [215]. The anisamide moiety was directly attached to the $\mathrm{ON}$ on resin by conventional solid phase-supported chemistry using a phosphoramidite reagent [216]. At $50 \mathrm{nM}$, the trivalent conjugate showed a more increased uptake in PC 3 cells (2-fold) than the monovalent conjugate (1.5-fold) as compared to the non-conjugated PS ASO without any noticeable toxicity. The induction of splice correction turning on luciferase expression was found to be 4 -fold increased using the trivalent anisamide conjugate, strongly indicating a preference for multivalency (the monovalent anisamide conjugate did not show significantly enhanced splice-switching relative to the non-conjugated ASO reference). With respect to the concomitantly improved uptake (2-fold increase) and biological efficacy (4-fold increase) of the trivalent conjugate, there appears to be a clear preference for receptor-mediated endocytosis over other forms of internalization. However, more recent results question the delivery of such conjugates via sigma-receptors due to emerging evidences that sigma-receptors might not be present on cell surfaces [202,217].

\subsection{Anandamide Conjugates}

Anandamide ( $\mathrm{N}$-arachidonoylethanolamine, AEA) is an endogenous ligand of the vanilloid TRPV1 receptor [218] as well as of the cannabinoid receptor [219] that is particularly expressed in human B-cells such as BJAB [220] and neuronal cells such as RBL-2H3 [221]. These cells are usually difficult to transfect and are therefore attractive for a cell-targeting approach exploiting the aforementioned ligand-receptor interaction with corresponding $\mathrm{ON}$ conjugates.

Carell et al. employed a postsynthetic (solution-phase) approach for the attachment of anandamide at the $3^{\prime}$-end of a 20-mer siRNA's sense strand by the Cu-catalyzed alkyne-azide click reaction (CuAAC). The resultant conjugate was envisioned to target Renilla luciferase in a reporter gene assay [222]. The CuAAC step was performed using azido-triethyleneglycol-substituted anandamide and a C-5-octadiyne 2'-deoxyuridine moiety (reaction not shown). Confocal microscopic imaging of RBL-2H3 cells, appropriate for simulating neurons $[223,224]$, proved efficient uptake of AEA-modified ds DNA as well as AEA-modified siRNA, whereas the non-conjugated references failed. Biological activity was evaluated via the reduced expression of luciferase in comparison with established ON-cholesterol conjugates. This proved the AEA conjugate to be slightly more potent ( $50 \%$ reduction) than the cholesterol conjugate ( $45 \%$ reduction) at $500 \mathrm{nM}$ in RBL-2H3 cells. To further evaluate the potential of this new conjugate towards actual endogenous targets, an assay was set up to determine the reduction of spleen tyrosine kinase (SYK) expression, a target for the treatment of inflammatory disorders $[225,226]$. AEA was connected to the siRNA required for silencing SYK expression [227] and administered to RBL-2H3 cells, showing the AEA conjugate again to be more active $(60 \%$ reduction of SYK activity) than the cholesterol conjugate ( $40 \%$ reduction). To further highlight anandamide as a highly promising candidate for cellular targeting, silencing of Renilla luciferase was evaluated in absence and presence of jetPRIME ${ }^{\mathrm{TM}}$ as transfecting agent. In a concentration range from $10 \mathrm{nM}$ to $1 \mu \mathrm{M}$, the sole AEA conjugate showed higher silencing of luciferase expression, de facto rendering jetPRIME ${ }^{\mathrm{TM}}$ useless alongside strongly reduced toxicity in BJAB cells.

Further improvements of this system towards a set of dendritic siRNA nanostructures targeting the mRNA of nucleo- and phosphoprotein of rabies lyssavirus (RABV) were made by Carell et al. as well [228]. Both proteins are essential for viral replication [229,230] and were targeted by a 20-mer siRNA with AEA attached to it in the same manner as in the aforementioned example (Figure 3) [222]. The crucial building block of the dendrimeric structure was a triazido derivative of pentaerythritol, with three siRNA units coupled to it and one connected AEA moiety to give a trivalent 
ON construct (AEA-[3siRNA], structure not shown). Three units of a diazido building block coupled to the pentaerythritol analogue led to a final structure with six siRNA units and one AEA moiety (AEA-[6siRNA], structure not shown). Finally, three units of the pentaerythritol derivative clicked to the triazido core yielded a construct with nine siRNA units and one AEA moiety (AEA-[9siRNA], Figure 3). The efficacies of these remarkable structures were first evaluated again using a dual luciferase reporter gene assay in RBL-2H3 cells. Thus, AEA-[3siRNA] showed a decrease of luciferase expression of $50 \%$ at one third $(166 \mathrm{nM})$ of the concentration used for monovalent AEA-[1siRNA] (20\% at $500 \mathrm{nM})$, maintaining the overall amount of siRNA equal for the purpose of direct comparison. AEA-[9siRNA] still showed $20 \%$ decrease of luciferase expression in spite of a very low concentration of $55 \mathrm{nM}$. The activity was further improved by attaching one glucose unit to the $3^{\prime}$-end of the antisense strands of AEA-[3siRNA], thus enhancing endosomal stability [231] and affording higher intracellular amounts of ON [232] (AEA-[3siRNA]-Glc, showing 80\% decrease of luciferase expression). The activity of AEA-[3siRNA] targeting Tet1 (that is involved in differentiation processes in ENC1 neuronal stem cells [233]) was again found to be higher than the monovalent conjugate, displaying 50\% inhibition at $125 \mathrm{nM}$ while unmodified siRNA failed.

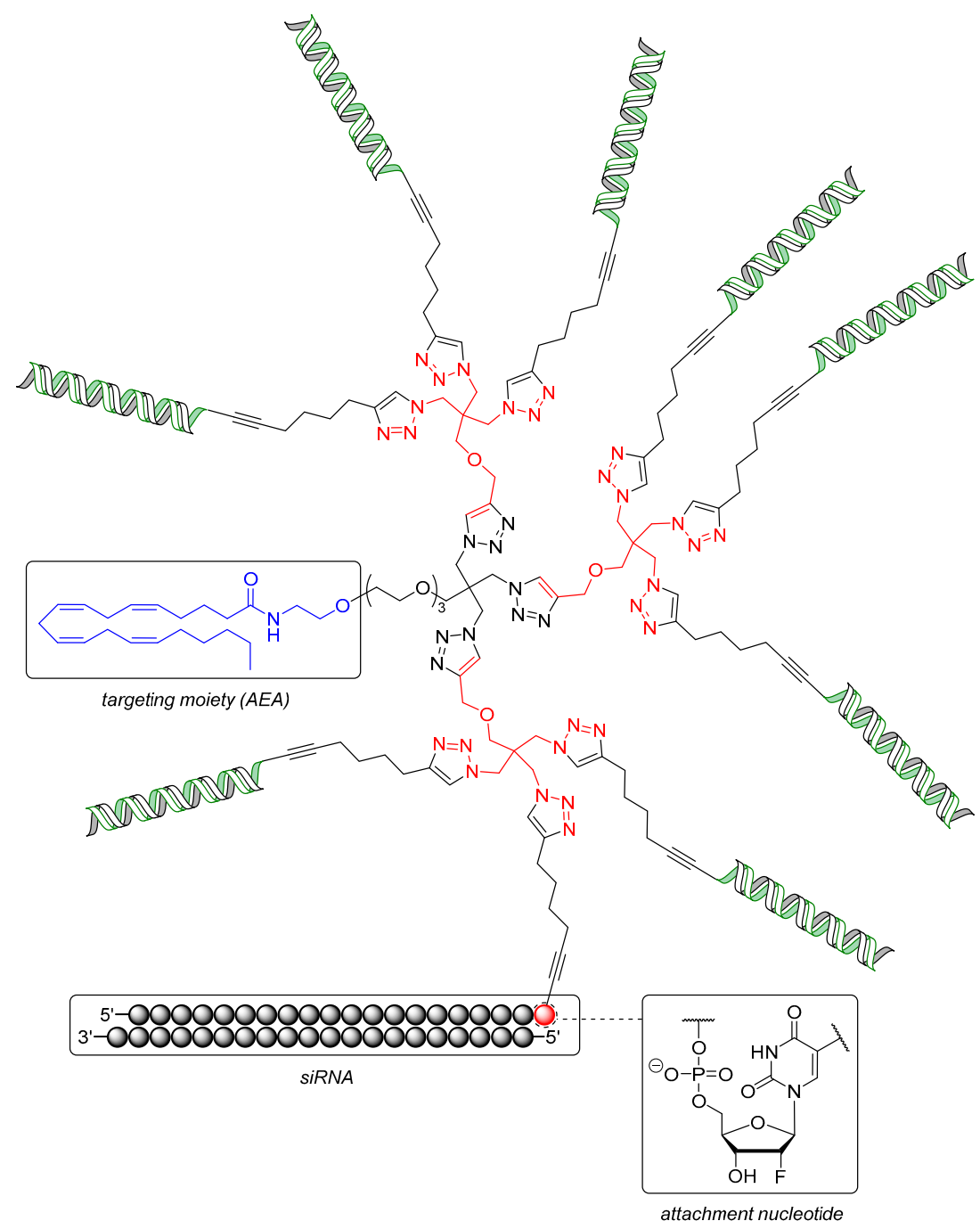

Figure 3. Structure of the dendritic siRNA-containing construct AEA-[9siRNA] equipped with an anandamide (AEA) targeting moiety (blue) and branching units (red: triazido pentaerythritol motif). The siRNA passenger strand (green) is covalently attached to the dendritic scaffold via a uridine-derived attachment nucleotide. 
Finally, RABV-infected E14 cortical neurons, which are usually difficult to transfect [234,235], were tested with AEA-[3siRNA]-Glc targeting viral nucleo- $(\mathrm{N})$ and phosphoproteins $(\mathrm{P})$. The titers of both N- and P-proteins of RABV were reduced by two orders of magnitude relative to scrambled AEA-siRNA and by one order of magnitude compared to siRNA transfected with Lipofectamine ${ }^{\mathrm{TM}}$ 2000 at $1 \mu \mathrm{M}$. Overall, monodisperse conjugates of small molecules covalently attached to siRNA dendrimers potentially enable efficient gene silencing in cells that are difficult to address otherwise.

\subsection{Folate Conjugates}

Folate (folic acid, FolA) is an important member of the vitamin B family and represents an essential nutrient participating in the biosynthesis of purines and pyrimidines [236] as well as in amino acid metabolism as a supplier of C-1 building blocks [237]. Several tissues express miscellaneous folate transport proteins such as PCFT [238], RFC [239], and three isoforms of folate receptors (FR) [240]. Among the latter, isoform $\alpha$ is the most abundant congener regarding cancer [241]. In general, FR are cell surface glycosyl phosphatidylinositol (GPI)-anchored glycoproteins to which folate has high affinity $\left(K_{\mathrm{D}}=0.1 \mathrm{nM}\right)$ [242]. FR are overexpressed in different cancers, e.g., ovaries [243], oral carcinoma [244], malignant pleural mesothelioma [245], and breast cancer [246], owing to the need of growing tumors for high amounts of folate to enable rapid cell division. This makes FR promising entities for the cellular targeting of cancerous tissues. Consequently, conjugates derived from folic acid are already extensively used in drug delivery systems against cancer $[247,248]$ and proved adequate for directed drug delivery. In this context, major challenges are uptake selectivity in desired tissues, thus avoiding unspecific distribution to non-malignant cells, and the potential toxicity of transfecting agents if antitumor ON therapeutics are envisioned to be used. Targeting FR might enable to overcome both of these hurdles because folate-conjugated therapeutics enter cells only via interaction with FR [249,250], and these are considerably overexpressed in many types of cancer. Non-malignant mammalian cells predominantly use transport proteins such as RFC for folate uptake, and these particularly bind reduced forms of the folate ligand [251]. In general, folate is an abundant and well-tolerated effector that is efficiently distributed in humans.

In a proof-of-concept study, Dohmen et al. [244] constructed a monodisperse FolA-PEG ligand that was coupled (by CuAAC) to a 22-mer siRNA having a bio-cleavable alkyne moiety at the $5^{\prime}$-end of its sense strand. The siRNA was designed to silence a reporter GFP-luciferase fusion gene in FR-positive KB/GFPLuc cells [252-254] to demonstrate efficacy of the conjugate. Internalization of the FolA-PEG-siRNA conjugate was confirmed by fluorescence microscopy with an additional Cy5 label at the $5^{\prime}$-end of the siRNA antisense strand. However, no silencing activity was detectable due to trapping of the conjugates in endosomes. Therefore, a monodisperse polycationic carrier based on polyethylenimine-like 1,2-diaminoethane units [255] was applied to form polyplexes mediating endosomal escape via the proton sponge effect [256]. Silencing of GFP was then found to be dose-dependent and an $80 \%$ reduced expression at $25 \mathrm{nM}$ was ascertained, whereas complexed non-conjugated siRNA or PEG-siRNA did not exhibit any effect at all. This proved the FolA-FR ligand-receptor pair to be suitable for the targeted delivery of $\mathrm{ON}$ via attachment of FolA as a small molecule targeting unit.

In analogy to the AEA-conjugate described above, Carell et al. [222] proved silencing in another reporter gene assay to be $50 \%$ at $1 \mu \mathrm{M}$ using a FolA conjugate, with the ligand attached (by CuAAC) to the nucleobase at the $3^{\prime}$-end. However, in recently published work by Desaulniers et al., a remarkable conjugate was applied in HeLa and HT-29 cells with a FolA unit at several positions within an siRNA, representing the first FolA conjugate ever constructed in this fashion (Figure 4) [51]. An N-propargyl diethanolamine-derived unit was chosen as anchor point for subsequent FolA conjugation (via CuAAC) and inserted between two nucleotides at position 10, thus replacing a single nucleotide. This strategy also aimed at a destabilization of the central region of siRNA that spans the Ago2 cleavage site, thus leading to enhanced silencing activity [46,49]. Two conjugates with FolA-modified backbones were tested in a reporter gene assay in HeLa cells and showed a significant degree of silencing with 
$\mathrm{IC}_{50}$ values of $171 \mathrm{nM}$ and $129 \mathrm{nM}$, respectively, after $24 \mathrm{~h}$. Even at $1 \mathrm{nM}$, both FolA conjugates still exhibited $20 \%$ inhibition whereas non-conjugated siRNA did not show any silencing at all. As anticipated, no silencing was observed in HT-29 cells for all siRNA targeting luciferase. HT-29 cells express 3-fold less FR, rendering them as a suitable FR-negative control. Compared to the previous work by Carell et al. in which FolA is installed at the $3^{\prime}$-end $\left(\mathrm{IC}_{50}=1 \mu \mathrm{M}\right)$, a 5 -fold increase in silencing activity was achieved applying FolA-conjugation at the internal Ago2 cleavage site of the sequence [236]. The potential of this approach was also investigated with structures containing variable spacer lengths between backbone and ligand [52] as well as with cholesterol conjugates within the passenger strand [53]. However, the conjugate with internal modification was further tested in HeLa cells targeting endogenous Bcl-2, an anti-apoptotic protein that is overexpressed in several types of cancer $[257,258]$. At $1 \mu \mathrm{M}$, a reduction of $70 \%$ of Bcl-2 expression after $24 \mathrm{~h}$ was found, proving this extraordinary approach for a small molecule-ON conjugate to be a promising strategy for additional future studies.

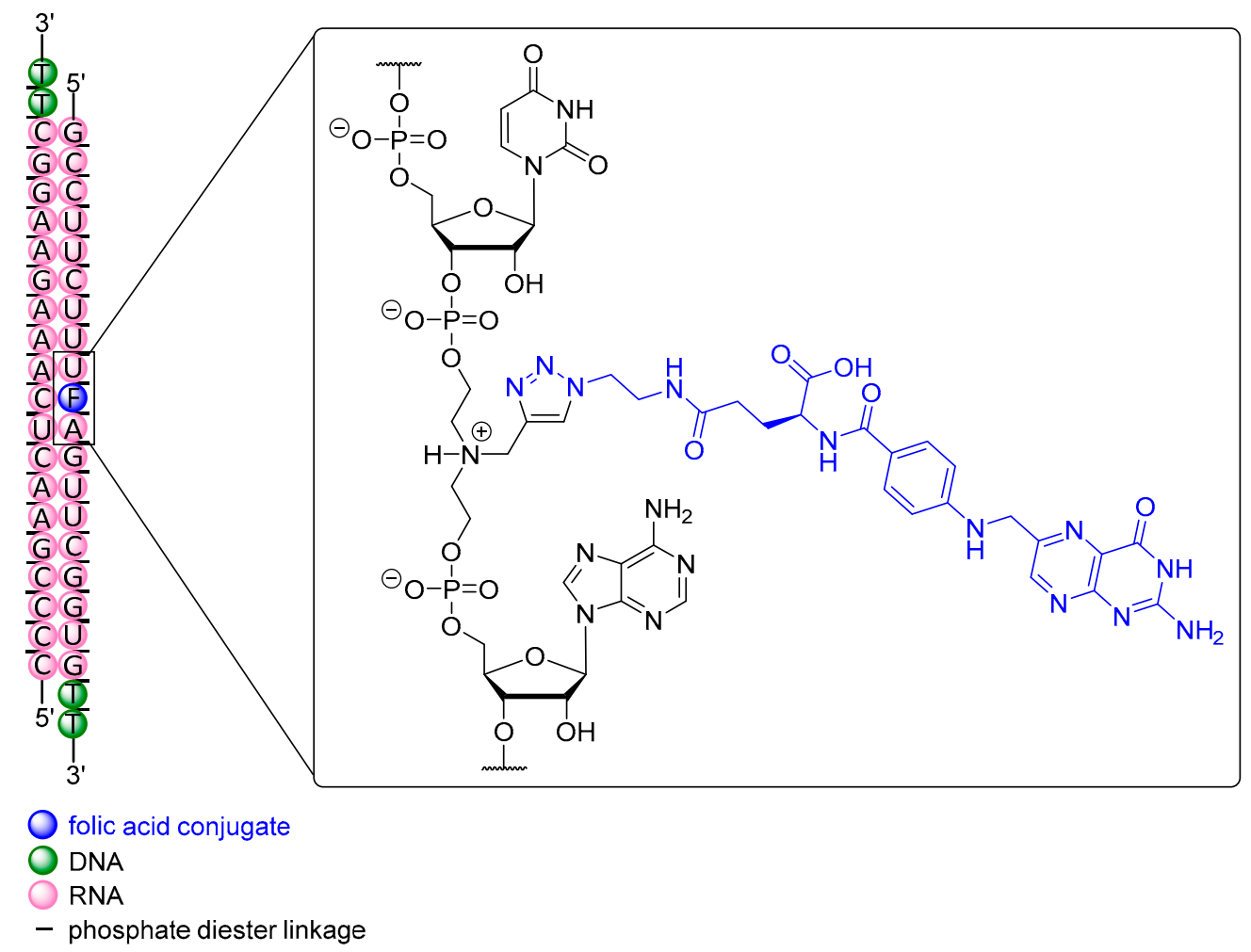

Figure 4. Internally modified folic acid-siRNA (passenger strand) for the silencing of Bcl-2 expression. The $5^{\prime}$-ends of siRNA strands are phosphorylated (not shown).

\subsection{Carbachol Conjugates}

Due to its structural similarity to acetylcholine, carbachol is a parasympathomimetic drug that binds to G protein-coupled muscarinic (mAChR) as well as to nicotinic (nAChR) receptors [259]. Muscarinic receptors are targeted by small molecules for the treatment of neuronal disorders such as schizophrenia and Parkinson's disease [260] as well as COPD [261].

Pauley et al. [262] exploited the ligand-receptor pair carbachol-muscarinic type 3 (M3R) to address Sjögren's syndrome, a long-term inflammatory rheumatological auto-immune disease affecting moisture-producing glands, in particular the parotid gland. Affected patients suffer from loss of secretory functions of lacrimal glands and are at risk to develop lymphoma when the disease progresses [263]. The current therapy for Sjögren's syndrome is based on secretagogues such as pilocarpine $[264,265]$ to induce secretion via muscarinic receptor stimulation [266], mainly focusing on treating symptoms and lowering the risk of developing cancer [267]. However, it does not 
address the underlying causes of secretory dysfunction [262]. In the mentioned work, carbachol was post-synthetically conjugated to the $5^{\prime}$-end of a 19-mer siRNA sense strand via carbamate formation between a $5^{\prime}$-terminal amino group and activated choline (structure not shown). The siRNA was designed to target caspase-3 to prevent cytokine-induced apoptosis. Cytokines are main regulatory polypeptides of the innate and adaptive immune system and control all aspects of duration and modulation of the immune response [268]. In the case of Sjögren's syndrome, however, an inherent imbalance of pro-inflammatory cytokines such as INF and TNF- $\alpha$ (overexpressed) and anti-inflammatory congeners such as TGF- $\beta$ (low expression) leads to damage in glands, thus ultimately causing decreased secretory function [269]. To investigate the potential effect of the aforementioned siRNA, the synthesized conjugates were transfected into HSG cells that mimic $\mathrm{Ca}^{2+}$-signaling of salivary glands [270] resulting from receptor binding of carbachol. Measuring the expression levels of caspase- 3 after $48 \mathrm{~h}$ revealed a reduction of $78 \%$ at $100 \mathrm{nM}$, whereas non-conjugated siRNA failed due to insufficient uptake. The latter was proven by calcium release assays and fluorescence experiments. Finding OAS-1 and MX-1 levels unchanged confirmed that no unspecific interferon response caused this downregulation of caspase-3. Such ON-small molecule conjugates therefore could be a starting point for a novel curative treatment for patients suffering from Sjögren's syndrome instead of current symptom-oriented therapies.

\subsection{Estrone Conjugates}

To the best of our knowledge, there are very few examples of single or non-formulated ON directly conjugated to estrone $\left(\mathrm{E}_{1}\right)$ applied in any therapeutic approach. Bang et al. synthesized two estrone-derived phosphoramidites (one bearing an octyl spacer) and attached them to the 5'-end of a 21-mer siRNA targeting vascular endothelial growth factors (VEGF) [271]. VEGF is an important signal protein family involved in the de novo formation of blood vessels (angiogenesis) as well as in lymphangiogenesis [272,273]. It is overexpressed in many types of cancer [274] as it is responsible for the permeability of blood vessels [275] and thus opens the blood-tumor barrier [276], ultimately causing metastasis [277] in particular in breast cancer [278]. $\mathrm{E}_{1}$ represents one of the natural endogenous female sex hormones besides estradiol and estriol [279] and acts as an agonist of the estrogen receptors alpha $(E R-\alpha)$ and beta $(E R-\beta)$ [280]. Consequently, $E_{1}$ conjugates were tested in ER-positive MCF-7 cells and showed a 3-4-fold enhanced silencing of VEGF expression as compared to non-conjugated siRNA (20\%) without transfecting agents at $50 \mathrm{nM}$. However, nuclease stability remained unchanged, leading to $80 \%$ degradation after $24 \mathrm{~h}$, suggesting that the enhanced activity resulted from improved uptake as also confirmed by confocal imaging. The conjugates equipped with an siRNA targeting lamin A/C mRNA [281] (that encodes a set of proteins being part of the inner nuclear membrane) were tested in ICR mice. Mutations in the LMNA genes further result in severe diseases, e.g., the Hutchinson-Gilford progeria syndrome [282] or several muscular dystrophies [283]. The results showed a clear downregulation of lamin A mRNA in a range of tissues, particularly in mammary glands by $60 \%$ at 40 nmol per mouse after $48 \mathrm{~h}$, whereas non-conjugated siRNA did not exhibit effects in any tissue at all. Hence, exploiting ligand-receptor interactions by means of small molecule conjugation to $\mathrm{ON}$ again gave superior efficacy relative to the administration of standard siRNA for gene silencing.

Recently, Venyaminova et al. [284] reported the development of a new solid phase-supported approach to attach several functional amino-modified ligands, in particular estrone, to the $5^{\prime}$-end of protected $(\mathrm{dT})_{7} \mathrm{ON}$ model sequences by $N, N^{\prime}$-disuccinimidyl carbonate (DSC)-mediated carbamate formation (Scheme 1). This strategy enabled variations in the length and size of spacer units, e.g., hexamethylenediamine, between an $\mathrm{ON}$ and (multiple) amino-modified ligand(s) by several successive reactions. Employing this methodology can overcome issues correlated with post-synthetic approaches such as the search for a suitable solvent (mixture) for post-synthetic modifications with highly hydrophobic entities. Furthermore, the often moderately yielding syntheses of phosphoramidite derivatives of effector molecules is rendered obsolete. A straightforward introduction of an amino 
group in a position that does not impede receptor interaction is thus sufficient for the conjugation of small molecules with therapeutic $\mathrm{ON}$ on resin.

It also should be noted that a conjugate with an estrone-appended polyion micelle to deliver a complexed cytotoxic peptide to breast cancer cells was recently reported [285]. Targeting ER- $\alpha$-related diseases is attracting growing interest, in particular in the case of hormone-responsive types of breast cancer. Readily prepared ON conjugates with small molecules to enable antisense-mediated gene knockdown represent a promising option to further exploit ER binding for therapeutic purposes.

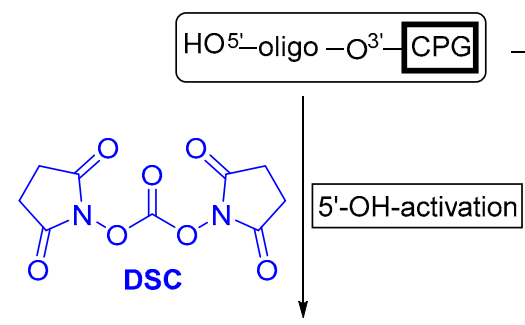

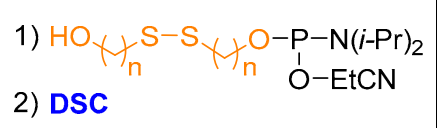

biolabile linker attachment

$\mathrm{OH}$-activation
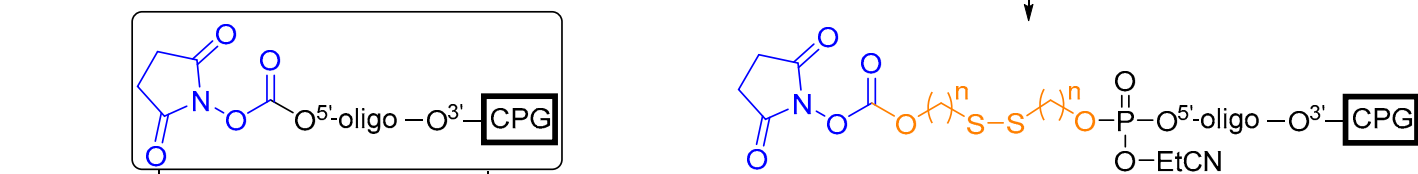
TM-NH

direct
ligand attachment

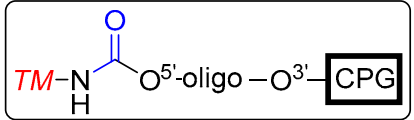

A spacer elongation $\mathrm{HO}_{Y_{\mathrm{n}}} \mathrm{NH}_{2}$

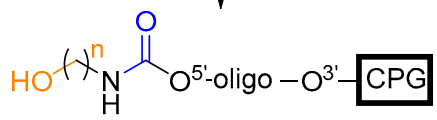
DSC OH-activation

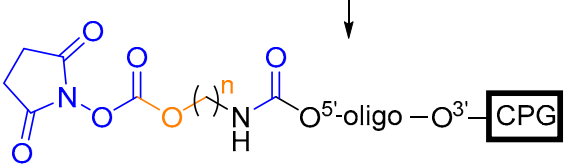

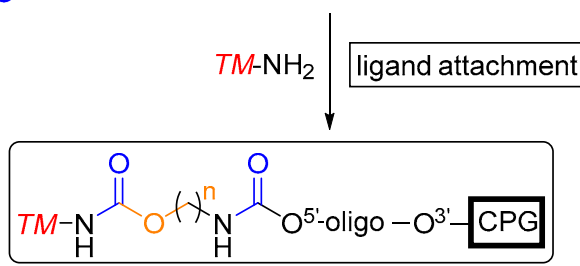

\section{C}

Scheme 1. The potential of solid phase-supported synthesis for the preparation of $5^{\prime}$-conjugated $\mathrm{ON}$ based on carbamate formation (DSC $=N, N^{\prime}$-disuccinimidyl carbonate). (A) Direct synthesis of 5'-functionalized ON. (B) Attachment of a biolabile linker with subsequent carbamate formation and attachment of the targeting moiety. (C) Spacer elongation via successive solid phase-supported reactions with final attachment of the targeting moiety. 


\subsection{GalNAc Conjugates}

The main strategy for inhibiting genes expressed in hepatocytes involves the exploitation of the asialoglycoprotein (Ashwell-Morell) receptor that is highly expressed in hepatocytes [286]. Upon binding, glycoproteins terminated with $\mathrm{N}$-acetylgalactosamine (GalNAc) are readily internalized via clathrin-mediated endocytosis [287]. The discovery that this receptor can be exploited for tailor-made drug delivery [288], even for therapeutic ON [289], paved the way for extensive research on delivery formulations [290] to address targets previously classified as 'undruggable'. These included, for instance, genes of hepatitis C virus (HCV) [291] or lipoprotein A [292] that is correlated with heart attacks and strokes. Nowadays, many GalNAc conjugates are known [293-296] and some recent examples are discussed here [54,297-299], in particular multivalent GalNAc motifs that proved to have superior targeting efficiency [300,301] when combined with established ON backbone modifications [302].

In rather recent work [299], multivalent di- [(GalNAc $\left.)_{2}\right]$ and triantennary [(GalNAc $\left.)_{3}\right]$ GalNAc units were installed via a trans-4-hydroxyprolinol linker to a solid support to yield a set of $3^{\prime}$-end (sense strand) modified 21-mer siRNA with PS backbone at $3^{\prime}$-ends and 2'-fluoro-, 2'-OH- and 2'-O-methyl motifs within the strands. Cellular uptake of these conjugates was tested at $20 \mathrm{nM}$ in freshly isolated primary mouse hepatocytes [303] using a fluorescence-based assay. A comparison between triantennary and biantennary GalNAc conjugates in vitro revealed a correlation of ligand binding affinity and increased uptake, with the latter being 8-fold higher for (GalNAc) $)_{3}$ and 3-fold higher for (GalNAc) 2 relative to non-conjugated siRNA or a biantennary conjugate with glucose (as negative control). Treatment of hepatocytes gave efficient and rapid receptor cycling as expected based on previous literature [287], thus further proving a receptor-mediated process. The (GalNAc) ${ }_{3}$ conjugate was additionally tested for silencing of the rodent transthyretin (TTR) gene in vivo in C57BL/6 mice and showed $80 \%$ reduction of TTR expression with a single dose of $5 \mathrm{mg} / \mathrm{kg}$. A weekly dose of $2.5 \mathrm{mg} / \mathrm{kg}$ rendered TTR expression levels below $20 \%$ for over nine months, demonstrating that the conjugate was extremely effective upon subcutaneous injection that was superior to intravenous application. Mutated TTR genes cause hereditary transthyretin-mediated amyloidosis [304,305], a rare neurodegenerative disease [306,307] leading to paresthesia, muscular weakness [308] and autonomic dysfunction evoked by deposition of abnormal transthyretin in the peripheral nervous system [309,310].

Khvorova, Watts et al. demonstrated the two main approaches by which GalNAc motifs might be linked to therapeutic ON (Figure 5) [298]. The first strategy, termed 'cluster-based approach', follows the design principle of the aforementioned trivalent structure that is also used in the controversial drug candidate Revusiran [311,312] ( $\mathrm{Gal}_{3} \mathrm{C1}$, Figure 5). Furthermore, it comprises an aminopropanediol-linked GalNAc dendrimer for $3^{\prime}$-end triantennary conjugates ( $\mathrm{Gal}_{3} \mathrm{C} 2$, Figure 5). The acyclic aminopropanediol linker has also been used with tetraethylene glycol spacers instead of amidoalkyl units in order to reduce hydrophobicity. Such multivalent dendrimers could also be installed post-synthetically via solution-phase chemistry at both ends of the ON. The second strategy constructs GalNAc cluster structures by multiple couplings of GalNAc-derived phosphoramidites (to furnish up to four repeating units) and is termed 'monomer-based approach'. The phosphoramidite monomer is based on L-threoninol with an amidoalkyl linker to the GalNAc unit (Gal ${ }_{3} \mathrm{M} 1$, Figure 5). The successively introduced targeting units can also be further separated by tetraethylene glycol spacers $\left(\mathrm{Gal}_{2-4} \mathrm{M} 2\right.$, Figure 5) to ensure optimal topology for binding to the heterooligomeric receptor [301]. However, both monomer-based structures were installed on solid support to afford $3^{\prime}$-end conjugates at the sense strand of a 22-mer siRNA that was further modified (i.e., $2^{\prime}$-O-methyl, $2^{\prime}$-fluoro, partial PS backbone). Cy3 was additionally introduced as a fluorophore at the $5^{\prime}$-end of the sense strand to monitor biodistribution. The new dendritic trivalent GalNAc conjugate and the novel linear tetravalent conjugate showed higher hepatocyte binding in FVBN/J mice than a comparable conjugate that already is in clinical trials [299,313]. $\mathrm{Gal}_{3} \mathrm{C} 2$ gave 2-fold, $\mathrm{Gal}_{3} \mathrm{M} 1$ 1.5-fold, and $\mathrm{Gal}_{4} \mathrm{M} 2$ even 3-fold increased association compared to $\mathrm{Gal}_{3} \mathrm{C} 1$ [299], and the same was found for liver accumulation. To investigate the silencing efficacy, structures were applied that targeted endogenous cyclophilin B (PPIB) [314]. The inhibition of cyclophilin proved to be effective for suppressing the replication of HCV [315-317]. 
All dendritic trivalent conjugates showed dose-dependent silencing of PPIB mRNA expression that was slightly better than for linear $\mathrm{Gal}_{4} \mathrm{M} 2(\sim 60 \%$ at a dose of $2.5 \mathrm{mg} / \mathrm{kg}, 80 \%$ at $10 \mathrm{mg} / \mathrm{kg}$ after $48 \mathrm{~h})$, representing a 2-fold increased potency relative to non-targeted controls. They were also recovered from the liver in 2-fold higher amounts than their linear counterparts. Of the linear multivalent conjugates $\mathrm{Gal}_{2} \mathrm{M} 2, \mathrm{Gal}_{3} \mathrm{M} 2$, and $\mathrm{Gal}_{4} \mathrm{M} 2$, the latter exhibited a stronger silencing effect and higher accumulation in the liver. This outcome observed for a tetravalent targeting moiety attached to siRNA is in some contrast to previous results for ASO [318,319], for which bivalent targeting moieties exhibited at least equal silencing than trivalent derivatives. This might demonstrate that the topology of such targeting units can be more relevant than valency for efficient receptor binding [320] with small molecules.

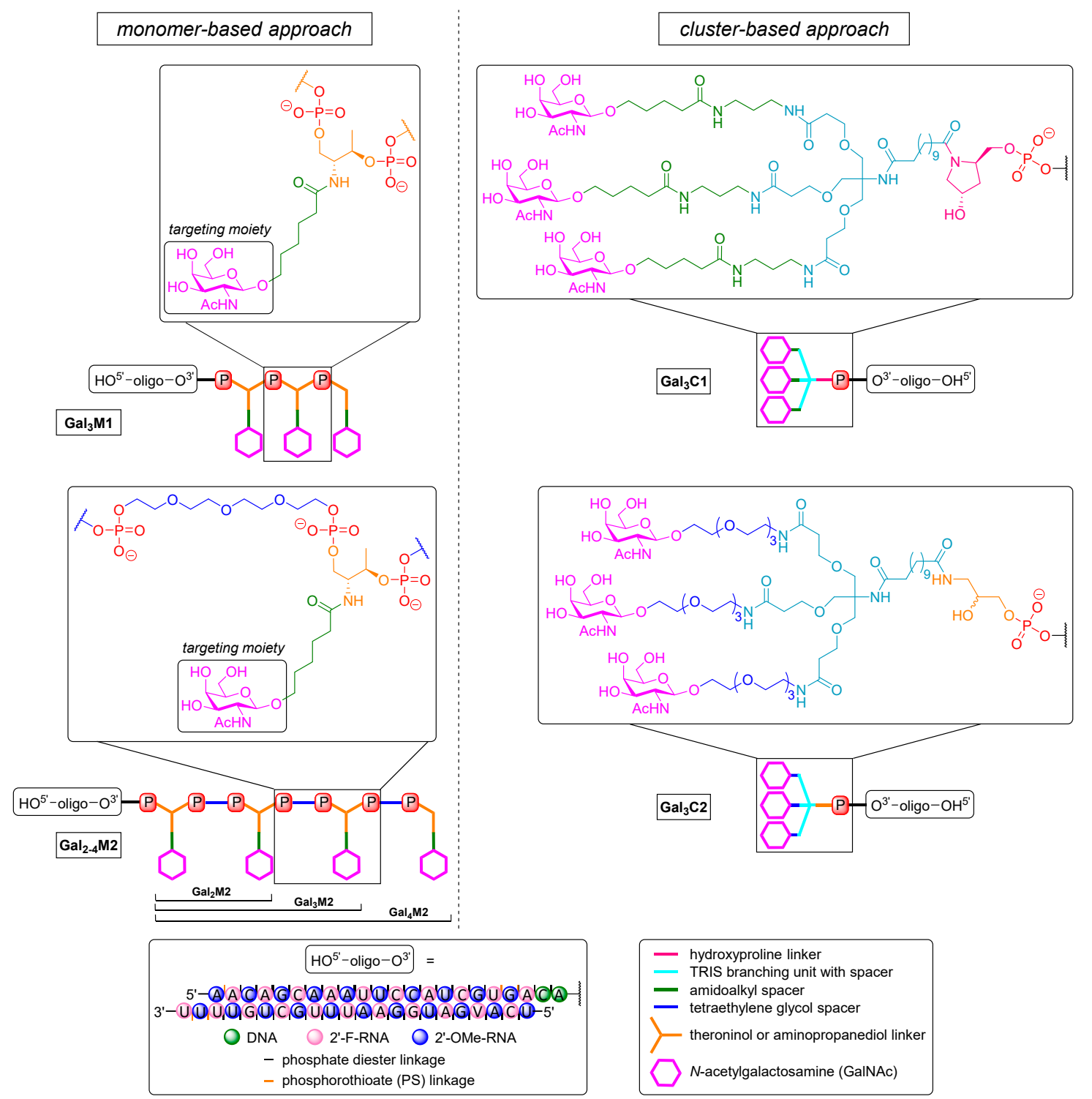

Figure 5. Overview of GalNAc conjugate structures targeting endogenous cyclophilin B. (Left) 'monomer-based' $\mathrm{Gal}_{3} \mathrm{M} 1$ and $\mathrm{Gal}_{2-4} \mathrm{M} 2$ are clusters constructed by successively reacted GalNAc-derived phosphoramidites with (M2) and without (M1) TEG spacer. (Right) the 'cluster-based' novel $\mathrm{Gal}_{3} \mathrm{C} 2$ unit (aminopropanediol-based) in comparison to the clinically studied $\mathrm{Gal}_{3} \mathrm{C} 1$ motif (prolinol-based) [321].

In other rather recent work, a unique dual cholesterol-GalNAc conjugate was used to lower nephrotoxicity [322] related to a certain class of ASO therapeutics (SPC5001) [323,324] by altered renal 
distribution with retained liver targeting. Cholesterol conjugation is known to extend the half-life of $\mathrm{ON}$ in blood, which leads to decreased kidney accumulation [325] and (as for GalNAc derivatives) enables liver targeting [326,327], but in this case, in non-parenchymal cells [328]. Wada et al. [297] combined the aforementioned 13-mer PS ASO (SPC5001) [329] with cholesterol as well as GalNAc units. This PS ASO construct targeted ApoB mRNA [329] to treat homozygous familial hypercholesterolemia [330] and contained deoxyribose nucleotides flanked by LNA moieties at both ends. The 5' -modification consisted of a linear arrangement of three trans-4-hydroxyprolinol phosphoramidites [331], each linked to a single GalNAc unit via an amidoalkyl linker. Cholesterol was attached either to the $5^{\prime}$-end via a tetraethylene glycole spacer ('5GN-5Chol') or to the 3'-end in the same manner ('5GN-3-Chol'). GalNAc units as well as cholesterol building blocks were connected to the ON via phosphate diester linkages to enable the formation of the free ASO for high activity after cellular uptake [332,333]. The conjugates were tested in male C57BL/6J mice and gave rather astonishing results. Gene silencing and cholesterol clearance exhibited by the dual conjugates 5GN-5Chol and 5GN-3Chol were found to be only slightly lower at a dose of $8.75 \mathrm{nmol} / \mathrm{kg}$ ( $~ 80 \%$ vs. $70 \%$ knockdown), indicating no significant benefit relative to the original GalNAc conjugate ('5GN'). On the other hand, renal uptake of the dual conjugates was reduced by one-fifth compared to $5 \mathrm{GN}$ and by one-fiftieth compared to the non-conjugated ASO. This is likely due to a transport mechanism mediated by cholesterol [325], i.e., binding to high-density lipoprotein as well as albumin [334], enhancing delivery to the liver [326]. Thus, exploiting the target preference of cholesterol for non-parenchymal cells [328] altered the biodistribution of the GalNAc conjugate that then exhibited inherent preference for hepatic tissue [319] towards reduced renal accumulation.

In recently published work [54], the influence of a single altritol hexopyranose modification (ANA) on the silencing potency of a 21-mer siRNA targeting rodent TTr mRNA was evaluated. This therapeutic ON (Patisiran) represents the first FDA-approved siRNA with activity against hereditary transthyretin-mediated amyloidosis [57] and was granted breakthrough status due to previous lack of an according drug. For potential further improvement, ANA was inserted once at each position in both the sense and the antisense strand. The resultant PS siRNA were further modified with 2'-fluoro and 2'-O-methyl units and conjugated to a trivalent GalNAc motif with a trans-4-hydroxyprolinol linker at the $5^{\prime}$-end. The GalNAc moiety was introduced by conventional phosphate diester formation, enabling release of the parent drug for optimal mRNA binding. As there are no naturally occurring enzymes for the cleavage of ANA, exo- and endonuclease-mediated degradation was blocked depending on the position of the ANA unit within the strands. Furthermore, the ANA-modification provides duplex stabilization via its hydroxyl group [335]. The conjugates were tested in primary mouse hepatocytes. It was found that placing the ANA unit at one of the $5^{\prime}$-ends furnished a 3-fold decrease in silencing activity in vitro relative to the parent drug. One explanation might be the impossibility for nucleoside kinases to phosphorylate the modified $5^{\prime}$-end [336], a process that is essential for the interaction with Ago2 [337] as part of RISC formation [338]. Placing the ANA unit in the seed region of the sense strand (positions 6 and 7) afforded nearly identical silencing of TTr mRNA as with the parent drug (95\% vs. 98\% degradation at $10 \mathrm{nM}$ ), as it was the case for the modification of position 16 (95\% degradation). Further studies regarding the stability of (dT) 19 with an ANA-modification at either end against degradation mediated by phosphodiesterase II (PDE II) or snake venom phosphodiesterase (SVPD), respectively, revealed strongly increased stability only against PDE II (90\% vs. 40\% retained full-length ON after $24 \mathrm{~h}$ ). Thus, using the ANA-modification in combination with GalNAc conjugation can add enhanced 5'-exonucleolytic stability to potent small-molecule conjugates of therapeutic ON.

\section{Conjugation of ON with Small Molecules for Enhanced Endosomal Release}

\section{Conjugates with Retro-1}

The molecule Retro- 1 became a candidate for conjugation based on a high-throughput screening of small molecules to block the effects of bacterial toxins such as shiga [339] or ricin [340] via inhibition of 
retrograde toxin transport between early endosomes and the TGN/Golgi complex [191]. This furnishes the connection to ON delivery: internalization of ON via any form of endocytosis is followed by participation in cellular traffic of the therapeutic. Therefore, ON have to pass through numerous endomembrane compartments [152], leading to a sequestration of most of them in endosomes, thus ultimately weakening the biological effect due to a reduced abundance in the cytosol [341]. It was shown that besides other small molecules [342], Retro-1 can mediate the aforementioned effect and therefore improves the redistribution of SSO and ASO [343] to the cytosol, leading to an increased concentration of $\mathrm{ON}$ in the nucleus [344]. However, it does not improve the distribution of siRNA. Retro-1 blocks the retrograde trafficking pathway as it interacts with shuttling processes, hence causing rapid partial release of $\mathrm{ON}$ from a subset of endomembrane compartments [343].

Juliano et al. [345] prepared three Retro- 1 derivatives, covalently attached to the $5^{\prime}$-end of a 20-mer PS SSO with 2'-O-methyl modifications via conventional amidite coupling on resin, or via Michael-type click reaction and Diels-Alder cycloadditon (post-synthetic, solution-phase reactions, Figure 6). The conjugates were tested in a luciferase reporter gene assay with the well-known splice switching ON sequence SSO 623 [176] in HeLa Luc 704 cells. Unfortunately, none of the novel conjugates afforded an improvement in splice-switching activity over the dual use of SSO 623 with UNC7938 as a widely used endosome-destabilizing agent $[344,346]$ or even SSO 623 alone. The reasons for this have not been elucidated yet, but ongoing research attempts to use more potent analogues of Retro-1 [344,347] or variations of spacer units to overcome possible impairments with the splice-switching machinery.

solid-phase amidite approach

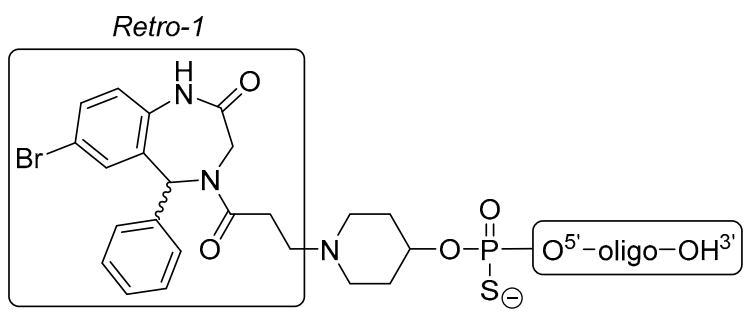

solution-phase postsynthetic approach
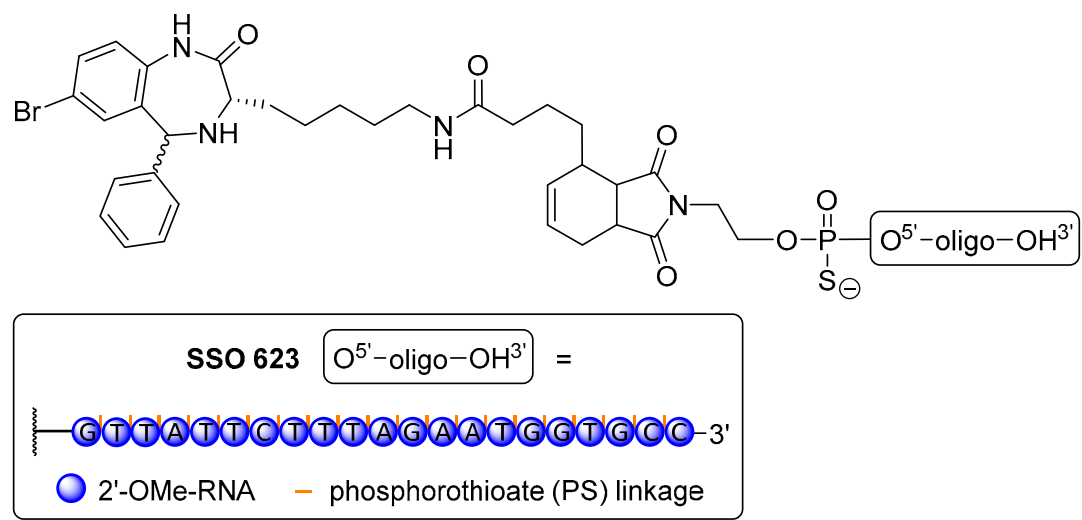

Figure 6. Retro-1 conjugates with the splice-switching ON SSO 623. (Top) on-resin conjugation product of Retro-1 with the ON using a 4-hydroxypiperidine-phosphoramidite. (Bottom) postsynthetic conjugation product of a Retro-1 derivative with the SSO via Diels-Alder reaction.

\section{Conjugation of ON with Lipophilic Small Molecules for Enhanced Membrane Penetration}

The attachment of lipophilic small molecules to $\mathrm{ON}$ (to give ' $\mathrm{LON}^{\prime}$ ) is a proven approach to enhance both (specific) cellular uptake [334,347] and endosomal release of the resultant conjugate [348]. The penetration of biological membranes by highly charged polar ON sequences is naturally hindered. This limits the overall activity of such therapeutic agents in vivo due to hampered cellular uptake (which is dependent on a plethora of pathways) and limited release from endocytotic vesicles. To overcome these intrinsic challenges, two major issues have to be addressed: poor cellular delivery and poor escape to the cytosol. The former can be improved by attaching lipophilic moieties to the ON 
to take advantage of the endogenous lipoprotein transport machinery. Thus, low-density lipoprotein (LDL) [349] and high-density lipoprotein (HDL) [350] mediate transport and internalization of lipids such as cholesterol. Furthermore, ON (in particular PS ASO) also interact with plasma proteins and/or lipoproteins to enter hepatocytes via receptor-mediated or non-mediated processes [326,351,352]. Hence, it was demonstrated that LDL and HDL facilitate internalization of lipid-ON conjugates [353]. In another study, conjugated ASO preincubated with lipoproteins were shown to have a lower effect in LDLR-knockout mice than in wild-type animals [354], further highlighting the benefit resulting from attached lipid small molecules.

With respect to endosomal release, exogenous $\mathrm{ON}$ have to participate in intracellular traffic and take advantage of the multitude of fusion and disjunction events to which vesicles are subjected in order to escape into the cytosol [355,356]. Lipid-ON conjugates bound to LDL [327] are mainly internalized via the clathrin pathway $[357,358]$ and thus undergo four common steps of downstream traffic after receptor binding: (i) pinching-off from the donor compartment (cell membrane with specific receptors binding the lipid); (ii) vesicle uncoating; (iii) actin/tubulin-mediated transport from the donor (cell surface) to the recipient (early endosomes); and (iv) SNARE protein-assisted fusion of both compartments to ultimately deliver the conjugate to its destination [359]. Within this pathway, a rather simple effect opens up the possibility to escape the aforementioned machinery and enter the cytosol. During pinching-off and fusion events, the formation of non-bilayer vesicles is observed [360,361] that tend to be leakier, hence providing an inherent opportunity for endosomal escape in particular for lipid-conjugated ON [362]. Crooke et al. demonstrated additional membrane destabilization due to lipids, thus increasing endosomal leakage [363]. Further enhanced protein and membrane binding enables in particular LON to remain bound to membranes controlling endosomal release [364]. Some previous and current work on LON is discussed in this section.

\subsection{Conjugates with Cholesterol}

Among lipophilized $\mathrm{ON}$, those modified with cholesterol represent by far the most abundant sub-group of conjugates and have therefore been reviewed elsewhere in detail $[334,347,352,365,366]$. Within the scope of this review, only some selected prominent or recent examples are presented in detail.

Soutschek et al. [367] have reported the first pioneering in vivo proof-of-concept for triggering RNAi with siRNA. They chose a 21/23-mer siRNA to target endogenous ApoB mRNA and silenced its expression and as a result total levels of cholesterol-with a conjugate bearing a cholesterol unit at its $3^{\prime}$-end. Cholesterol was installed via a pyrrolidine-derived linker on the solid support at the sense strand, with phosphorothioate linkages and two 2'-O-methyl nucleotides incorporated to ensure stability against exonuclease-mediated degradation (structure not shown). In C57BL/6 mice, the resultant construct decreased levels of ApoB-100 mRNA by 57\% in the liver and 73\% in the jejunum. ApoB-100 plasma levels were found to be decreased by 68\% after $24 \mathrm{~h}$, and the total amount of cholesterol was shown to be reduced by $40 \%$ at a dose of $50 \mathrm{mg} / \mathrm{kg}$. One explanation for this increased biological activity relative to non-conjugated $\mathrm{ON}$ might be the fact that the conjugate interacts with (serum) albumin or lipoproteins (LDL and HDL) to enter hepatocytes via their specific receptors, leading to some sort of cellular targeting [326,351,352]. This work has stimulated further research on the site-specific delivery of $\mathrm{ON}$ for the silencing of 'undruggable' targets.

Tang et al. [368] have described the conditional regulation of gene expression via spatiotemporal control of silencing activity with light as a non-invasive trigger (Figure 7). Therapeutic activity of small molecules [369] or ON [370] can be blocked ('caged') with photolabile moieties (PL), e.g., NPE [371], NPP [372], NPOM [373], and DMNPE [374]. In the case of ON, the photolabile units render them unable for hybridization when such units are attached to nucleobases, thus disturbing Watson-Crick base pairing. On the one hand, $\mathrm{ON}$ are thus more protected against immune response or exonuclease degradation [375,376], and on the other hand, they do not exhibit any premature silencing activity leading to off-target effects. As shown by Tang et al., attaching such a PL together with cholesterol to 
the $5^{\prime}$-end of the antisense strand of a 21-mer siRNA designed for downregulation of the Ago2 protein (Figure 7) resulted in failure to form the RISC [377]. However, photo-induced release $(\lambda=365 \mathrm{~nm})$ of native siRNA took place within just a few minutes, rendering the ON active again. Photomodulation of gene expression was also proven by effective silencing (after irradiation) of mitotic kinesin- 5 (Eg5) mRNA (that is crucial for mitosis [378,379]) using a photolabile conjugate. Compared to a positive control at $5 \mathrm{nM}$ (non-caged siRNA), Eg5 mRNA expression was slightly less reduced using the conjugate ( $80 \%$ vs. $60 \%$ ), but the total amount of cells arrested in the G2/M phase was nearly the same $(40 \%)$, showing the photo-activatable conjugate to be similarly potent as the parent drug.

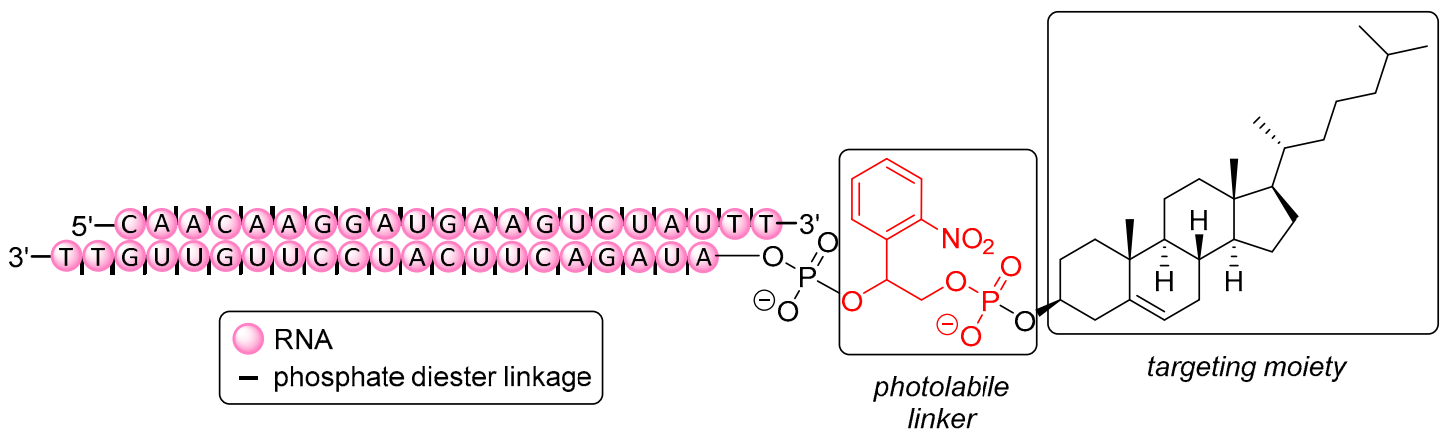

Figure 7. Cholesterol-modified caged siRNA targeting mitotic kinesin-5 (Eg5) mRNA.

In contrast to the attachment of small molecules either to the $5^{\prime}$ - or to the $3^{\prime}$-end of $\mathrm{ON}$, there are few approaches introducing cholesterol within an ON sequence via modified nucleoside building blocks. These have the cholesterol unit either connected to the nucleobase [55] or at the 2'-N-position in the case of amino-LNA [380], using conventional phosphoramidite chemistry for ON formation in both cases. In an early example, Letsinger et al. [381] used oxidative phosphoramidation on resin to attach amino-modified cholesterol via H-phosphonate chemistry to an internucleoside phosphorus. One can also choose non-nucleosidic cholesterol derivatives [382] as well as non-nucleosidic linkers designed for post-synthetic derivatization with cholesterol via a plethora of reaction types [365]. In a recent study, Nakajima et al. synthesized an ON conjugate having a cholesterol thiono triester within the phosphate backbone (structure not shown) and evaluated delivery and silencing activity relative to alternative cholesterol attachment to the $5^{\prime}$ - and $3^{\prime}$-ends for the first time [56]. A set of 13-mer PS ASO and phosphate-linked (PO) ASO designed to silence ApoB expression [329] was synthesized with LNA units at both ends to enhance stability against nucleases. Within the structure, a modified thymidine-derived $(\mathrm{T})$ phosphoramidite was inserted at several positions $(4,8$, and 10$)$ with a triethylene glycol-derived cholesterol attached to the phosphates. In general, adequate space between the $\mathrm{ON}$ and the small molecule as well as ideal placement of the latter are very important factors to be considered in the design of potent conjugates, in particular when the ligand is placed at the $5^{\prime}$ or $3^{\prime}$-end [56,332]. The delivery of $5^{\prime}(\mathrm{PS}), 5^{\prime}(\mathrm{PO})$, and T10 (PS) ASO conjugates in C57BL/6 mice at $0.5 \mathrm{mg} / \mathrm{kg}$ was strongly enhanced (15-fold, 3 -fold, and 10-fold, respectively). In contrast, the silencing efficacy of the conjugates remained insufficient except for the $5^{\prime}(\mathrm{PO})$-linked derivative (5-fold increase), all relative to non-conjugated ASO. These findings indicate that a rapid cleavage of the small molecule from the ON scaffold might be potentially mandatory in order to achieve increased silencing alongside improved delivery [328].

\subsection{Conjugates with $\alpha$-Tocopherol}

Several studies have been reported in which therapeutic ON were conjugated with $\alpha$-tocopherol $(\alpha-\mathrm{TP})$ for the purpose of efficient gene silencing [354,383-387]. $\alpha$-TP is one out of four tocopherol congeners $(\alpha, \beta, \gamma, \delta)$ that show inherent antioxidant [388], anticancer [389], anti-inflammatory [390], immuno-stimulatory [391], and nephroprotective properties [392,393]. Together with the three-fold unsaturated analogues, i.e., the four tocotrienols, they form the vitamin E family, a major bioactive 
class of essential nutrients for human metabolism [394,395]. Tocopherols are therefore considered to be effective ligands for drug delivery of poorly internalized ON therapeutics, also with respect to their active protein-mediated uptake [396,397], as described by Nishina et al. with the first $\alpha$-TP conjugate. A 27/29-mer siRNA [383] having $\alpha$-TP connected to the $5^{\prime}$-end of its antisense strand as well as several standard modifications (2'-O-methyl, partial PS backbone; structure not shown) was designed to reduce expression of endogenous $A$ poB in the liver, in order to reduce cardiovascular events after the dicer-assisted formation [398] of mature 21-mer siRNA including cleavage of the $\alpha$-TP targeting unit. The stability of the conjugate in mouse serum was improved 4-fold as compared to the non-conjugated siRNA (that was fully degraded after $8 \mathrm{~h}$ ). As shown via confocal imaging, the $\alpha$-TP conjugate was readily taken up by the liver, thus delivering the 27/29-mer as well as the mature 21-mer siRNA, whereas uptake of non-conjugated siRNA could not be found. Levels of endogenous ApoB-encoding mRNA in the liver were evaluated $48 \mathrm{~h}$ after administration of the conjugate in C57BL/6 mice and were decreased by $50 \%$, whereas no silencing with non-conjugated reference siRNA was observed at a dose of $2 \mathrm{mg} / \mathrm{kg}$.

Further work reported by the same group [384] showed a strong increase in delivery of a $5^{\prime}$ - $\alpha$-TP-modified 27-mer siRNA (2'-O-methyl, partial PS backbone; structure not shown) to neurons, particularly in the cerebral cortex and hippocampus, at low doses. After intracerebroventricular (ICV) administration in female Crlj:CD1 mice, non-conjugated siRNA could not elicit detectable target gene silencing, whereas an amount of $100 \mathrm{nmol} / \mathrm{kg}$ of the conjugate furnished $70 \%$ decrease of beta-site amyloid precursor protein cleaving enzyme 1 (BACE1) mRNA after seven days. A comparison with similar gene silencing trials $[399,400]$ highlighted the reduction of the required dose of siRNA by three orders of magnitude. The additional use of high-density lipoprotein (HDL) as transfecting agent ameliorated receptor-mediated uptake via HDL receptors [397,401]. This might also have an impact on the development of drugs against Alzheimer's disease [402,403]. In general, conjugated ASO preincubated with lipoproteins such as HDL showed lower effects in LDL-knockout mice than in wild-type animals, thus further proving receptor-mediated uptake exploiting this pathway [354].

Nishina et al. [354] reported the construction of a highly effective heteroduplex ON (HDO) consisting of a DNA/LNA-gapmer as a 13-mer PS ASO and a 31-mer cRNA complementary to this PS ASO, with the latter having an $\alpha$-TP unit at its $5^{\prime}$-end and some $2^{\prime}$-O-methyl modifications (structure not shown). This unique structure was applied to improve the delivery of the ASO via hybridization with the sense strand of an $\alpha$-TP-conjugated cRNA to evaluate silencing of ApoB mRNA [329] and of scavenger receptor class $b$ member 1 (Srb1) mRNA [404] in mice. The $\alpha$-TP-HDO was found to be 22-fold more potent $\left(\mathrm{ED}_{50}=38 \mu \mathrm{g} / \mathrm{kg}\right)$ than the sole PS ASO $\left(\mathrm{ED}_{50}=841 \mu \mathrm{g} / \mathrm{kg}\right)$ for the downregulation of ApoB expression in the liver. Three days after administration of $0.75 \mathrm{mg} / \mathrm{kg}$ to C57BL $/ 6 \mathrm{mice}$, ApoB mRNA levels were reduced by $50 \%$ and $40 \%$ using the PS ASO and the non-conjugated HDO, respectively. In contrast, a reduction of more than $90 \%$ of ApoB mRNA levels was observed for the $\alpha$-TP-conjugated HDO, while the employed cRNA alone did not exhibit any effect. The amount of $\alpha$-TP-HDO delivered to the liver was 5-fold higher relative to the non-conjugated HDO or the PS ASO alone. With respect to duration of ApoB mRNA silencing, the non-conjugated HDO exerted only $10 \%$ reduction after 14 days, whereas the $\alpha$-TP-conjugated HDO furnished $70 \%$ reduction even after 28 days. Srb1 levels in mice were reduced by $60 \%$ using the PS ASO alone at $10 \mathrm{mg} / \mathrm{kg}$. In contrast, the $\alpha$-TP-HDO conjugate afforded a reduction of Srb1 levels of more than $90 \%$ at the same dose. No detectable increase of IFN- $\gamma$ or TNF- $\alpha$ levels in any of these experiments indicated that no undesired immune-stimulatory effect had occurred. Using the same mouse model, Nishina et al. [385] have also evaluated the effect that several LNA-modifications have on the silencing efficacy towards ApoB1 and Srb1.

A comparative study [328] investigated the dose, efficacy, and duration of a trivalent GalNAc-, a cholesterol- and a 5'- $\alpha$-TP-conjugated 13-mer ASO [329] (all linkages PS-modified, LNA units at both ends; structures not shown). All three resultant conjugates targeted the same ApoB1 mRNA in hepatocytes as well as in non-parenchymal cells in male C57BL/6 mice. The $\alpha$-TP and cholesterol 
moieties were installed via conventional phosphoramidite chemistry on resin. The GalNAc unit was introduced post-synthetically via carbamate formation with an aminohexyl linker. At a dose of $1 \mathrm{mg} / \mathrm{kg}$ and relative to the non-conjugated ASO, all of these ASO conjugates exhibited multifold improved delivery of the ASO to the liver. However, only the cholesterol-ASO and the $\alpha$-TP-ASO showed higher delivery in non-parenchymal cells. In general, ASO tend to accumulate preferentially in non-parenchymal cells, but they are intrinsically more active in hepatocytes [405]. Similar results were obtained regarding the efficacy of ApoB mRNA silencing in both the liver as a whole and in hepatocytes, with the GalNAc conjugate being superior to the other congeners with the exception in non-parenchymal cells, in which the $\alpha$-TP conjugate showed the highest silencing efficacy. All conjugates displayed an extended duration of the silencing effect up to several days after injection while their half-lives were similar to the non-conjugated ASO. Overall, these results might provide options for a more efficient ON-mediated silencing of oncogenes in different types of liver cells, with conjugated small molecules steering the biological effect.

In a recent proof-of-concept study, a new potential platform technology for targeting intractable neurological diseases has been described [386]. The aim of this work was to modulate the properties of the blood-brain barrier (BBB) with ON. Thus, an HDO conjugate was designed to target the expression of organic transporter 3 (OAT3) in brain microvascular endothelial cells (BEMEC). OAT3 is almost exclusively expressed in BEMEC and represents an interesting drug target for several reasons. First, protocols exist for the quantification of biological activity of OAT3 with respect to its expression pattern within the BBB [406]. Second, no major pathological side effects are expected as demonstrated with oat3-knockout mice [407]. A PS ASO flanked by several LNA-modifications at both ends was hybridized with complementary $5^{\prime}-\alpha$-TP-cRNA (PS- and 2'-O-methyl-modified) to yield a potent HDO (Figure 8) [354]. This was used to target exogenous luciferase-fused OAT3 genes pre-transfected to C57BL/6 mice. Two of these model genes of OAT3 were downregulated by $86 \%$ and $50 \%$, respectively, at a dose of $32 \mathrm{mg} / \mathrm{kg}$ without the use of a transfecting agent. However, the silencing of one gene construct was accompanied with severe liver dysfunction and induction of IF $\alpha-\gamma$ and TNF- $\alpha$ in these mice. These observations were also made though when the sole ASO without conjugated $\alpha$-TP unit was administered. Nevertheless, this work has demonstrated an interesting approach to address neurological disorders via the use of a small molecule-conjugated $\mathrm{ON}$. This strategy might potentially contribute to improved therapies of diseases such as, for instance, multiple sclerosis [408] or Alzheimer's disease [409].

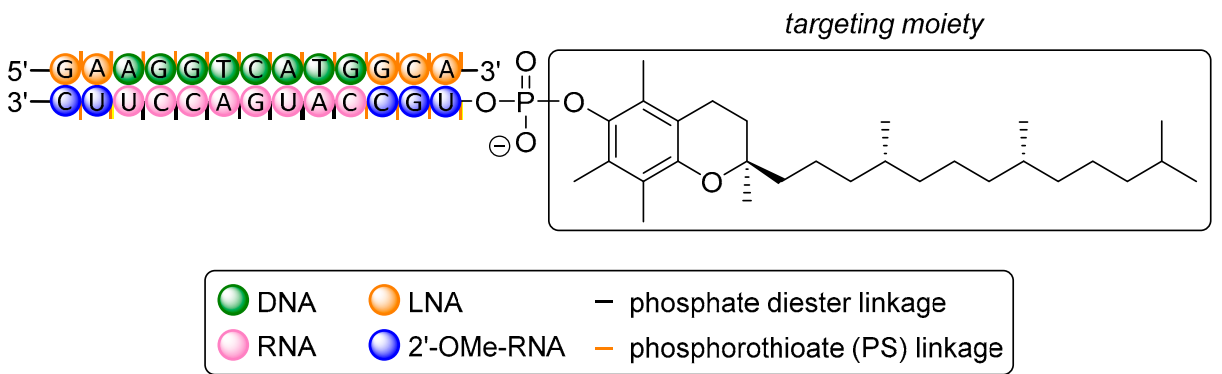

Figure 8. Structure of the $\alpha$-TP-HDO conjugate designed to target the expression of OAT3 in BEMEC.

\subsection{Conjugates with Squalene}

Squalene (SQ) is an endogenous triterpene, produced in the liver and skin as precursor in the biosynthesis of steroids such as cholesterol [410,411]. Due to its high hydrophobicity, conjugation of squalene to the $5^{\prime}$ - or $3^{\prime}$-end of an ON furnishes a highly amphiphilic construct tending to self-aggregate to nanostructures, ultimately leading to increased plasma stability without the need for formulating agents. This kind of self-aggregation might save the potential patient from undesired side effects related to the toxicity of common formulations [412,413] or a burst release of the drug from the formulation [414]. The concept of squalenylation has already been used in the context of drug delivery [415-419] since 
its first application to improve the delivery of gemcitabine, a cytotoxic nucleoside analogue used in anticancer chemotherapy [420].

Raouane et al. [421] attached the triterpene to an ON via Michael-type click reaction between a maleimide-modified squalene and a mercaptopropylphosphate residue at the $3^{\prime}$-end (sense strand) of a 19-mer siRNA [422] targeting RET/PTC1 (reaction not shown). The latter represents an oncogene found in papillary thyroid carcinoma [423] as it encodes an abnormal membrane tyrosine kinase [424]. The conjugate was tested in TPC-1 and in BHP 10-3 cells and did not show any growth inhibition or significant toxicity in vitro. However, in vivo testing of the SQ conjugate in nude mice revealed growth inhibition in xenocrafted tumors of $70 \%$ after injection of a $2.5 \mathrm{mg} / \mathrm{kg}$ dose. RET/PTC1 mRNA expression was reduced by $80 \%$ after $24 \mathrm{~h}$ whereas non-squalenylated siRNA displayed only $10 \%$ inhibition additionally using Lipofectamine 2000 as transfecting agent.

Urbinati et al. [425] constructed an SQ conjugate based on a 21-mer siRNA to silence the oncogene TMPRSS2-ERG [426] that is found in $50 \%$ of prostate-related cancers [427]. This new approach is aimed to bypass toxicity issues [428] of hormone-dependent prostate cancer treatment with flutamide [429], the standard in nonsteroidal antiandrogen therapy that thus provokes discontinuous treatment. Targeting the fused gene [430] consisting of TMPRSS2 [431] and ERG [432] that encodes ETS transcription factors [433] might also be a salvation for patients who suffer from androgen-independent [434] or castration-resistance prostate cancer $[435,436]$. Based on previous in vitro studies $[437,438]$, the SQ conjugate could only be applied with the aid of transfecting agents to cause tumor growth inhibition of $70 \%$ at $50 \mathrm{nM}$. However, uptake was ascertained without transfecting agents in vivo, evoking a 3-fold weaker tumor growth relative to non-conjugated siRNA at a cumulative dose of $1.8 \mathrm{mg} / \mathrm{kg}$ after 40 days. A reduction of $60 \%$ in mRNA levels of TMPRSS2-ERG oncogenes (REG4 and PHGR1) was found at $50 \mathrm{nM}$ after $72 \mathrm{~h}$, while non-conjugated siRNA did not exhibit any decrease at all. Overall, these results demonstrate that SQ conjugates can be therapeutically very effective, but that disparities between in vitro and in vivo activities may occur.

\subsection{Conjugates with Fatty Acids}

Besides other hydrophobic small molecules, unbranched fatty acids can also be attached to therapeutic ON. For instance, saturated congeners such as lauroyl $\left(C_{12}\right)$, myristoyl $\left(C_{14}\right)$, palmitoyl $\left(C_{16}\right)$, stearoyl $\left(\mathrm{C}_{18}\right)$, and docosanoyl $\left(\mathrm{C}_{22}\right)$ units as well as (poly-)unsaturated structures such as oleoyl $\left(\mathrm{C}_{18}\right.$, $\omega-9)$ and linolenoyl $\left(C_{18}, \omega-6,9\right)$ were conjugated to a 21-mer siRNA for in vitro targeting of ApoB mRNA [327]. With respect to their similarity to cholesterol, conjugates with bile acids are not further discussed within this review, but have been reviewed elsewhere [439-441].

The probably most relevant example of a fatty acid conjugate is Imetelstat (GRN 163L) that is currently in clinical trials phase II (trial reference NCT01731951) [442]. Imetelstat is a 13-mer thio-phosphoramidate $\left(\mathrm{N}^{\prime} \rightarrow \mathrm{P}^{\prime}\right)$ ASO that is modified at its $5^{\prime}$-end with a palmitic acid unit, attached via an aminoglycol linker (structure not shown). This drug candidate is intended to target human telomerase (hTR) for the treatment of myelofibrotic cancer [443]. Telomere elongation is frequently observed in cancer cells [444], rendering them 'immortal' due to maintained cell division or the lack of cell cycle arrest, while healthy cells undergo progressive telomere shortening upon repeated cell division [445]. To overcome this intrinsic property of cancerous cells, Herbert et al. chose palmitic acid as a small-molecule modifier to improve the poor delivery of the known ASO sequence [446] and to enhance its availability in target tissue. Assays in HME50-5E, PC3 (prostate cancer), and MDA-MB231 (breast cancer) cells revealed reduction of telomerase activity at $1 \mu \mathrm{M}$ by $73 \%, 93 \%$, and $69 \%$, respectively, representing a nearly 40 -fold increase [447] in activity relative to the non-conjugated ASO due to optimized pharmacokinetics.

More recently, plasma protein binding of palmitoyl, cholesterol, and tocopherol conjugates for the improved silencing of MALAT1 in rodent muscles has been studied [387]. Targeting skeletal muscle cells at the genetic level is a novel approach for the treatment of Duchenne muscular dystrophy [448]. The ASO drugs Eteplirsen [36] and Golodirsen [34] were developed to achieve this goal, but their 
success was limited [449]. MALAT1 was proven to also play a key role in metastasis of carcinomas [450] in mouse models and therefore represents a promising target for additional research. Østergaard et al. have investigated a 19-mer ASO (partial PS backbone, cEt-modified at several positions; structure not shown) conjugated to palmitic acid via an amidohexyl phosphoramidite in C57BL/6 mice and cynomolgus monkeys [387]. They have found stronger binding of all conjugates to albumin and additional binding to LDL and HDL as compared with the non-conjugated ASO, indicating a potentially improved delivery to target tissues. Rodents and monkeys were treated with a cumulative dose of $40 \mathrm{mg} / \mathrm{kg}$ over seven weeks, and expression levels of dystrophiamyotonica protein kinase (DMPK) mRNA were found to be 2- to 3-fold lower in several muscle tissues without any notable toxicity when $\alpha$-TP- or palmitoyl-conjugated ASO were applied. A cholesterol-conjugated ASO exhibited slightly higher toxicity in rodents and was therefore not tested in monkeys. Thus, the exploitation of plasma protein binding with fatty acid small molecules to enhance the potency of known ASO sequences demonstrated the effectiveness of this approach.

Another strategy to introduce highly lipophilic moieties into therapeutic $\mathrm{ON}$ is their attachment as $\mathrm{O}-2^{\prime}, 3^{\prime}$-ketal nucleolipids at the $5^{\prime}$-end (Figure 9) [451]. Barthélémy et al. connected such a di- $\mathrm{C}_{15}$ ketal nucleolipid motif to the $5^{\prime}$-end of a 20-mer PS ASO targeting translationally controlled tumor protein (TCTP) in prostate cancer cells. The mRNA encoding the cancer biomarker TCTP represents a potential therapeutic target [452] as it is overexpressed in several types of cancer including breast [453], lung [454], and particularly castration-resistant prostate cancer (CRPC) [455]. TCTP has been shown to be involved in cell cycle progression [456] and inhibition of programmed cell death [457]. In the advanced stages of prostate cancer, emerging resistance against adjuvant hormone therapy with androgens requires surgery or chemotherapy [458,459] with poor prognosis. An efficient cellular targeting and delivery of a suitable therapeutic ON might be an approach to overcome these issues.

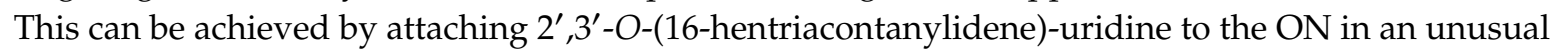
head-to-head fashion $\left(5^{\prime}-5^{\prime}\right)$ via its $5^{\prime}$-phosphoramidite. This remarkable structure tends to promote self-aggregation into micelles, thus improving delivery without additional transfecting agents via micropinocytosis in the same manner (98\%) as oligofectamine polyplexes of an unmodified ASO (100\%) in PC3 cells, but with reduced toxicity (relative to the non-conjugated PS ASO) in nude mice. Thus, the expression of TCTP was downregulated by $90 \%$ at $70 \mathrm{nM}$ with the nucleolipid-modified PS ASO, representing a 2 -fold increase in silencing activity relative to the nucleolipid-free reference ASO.

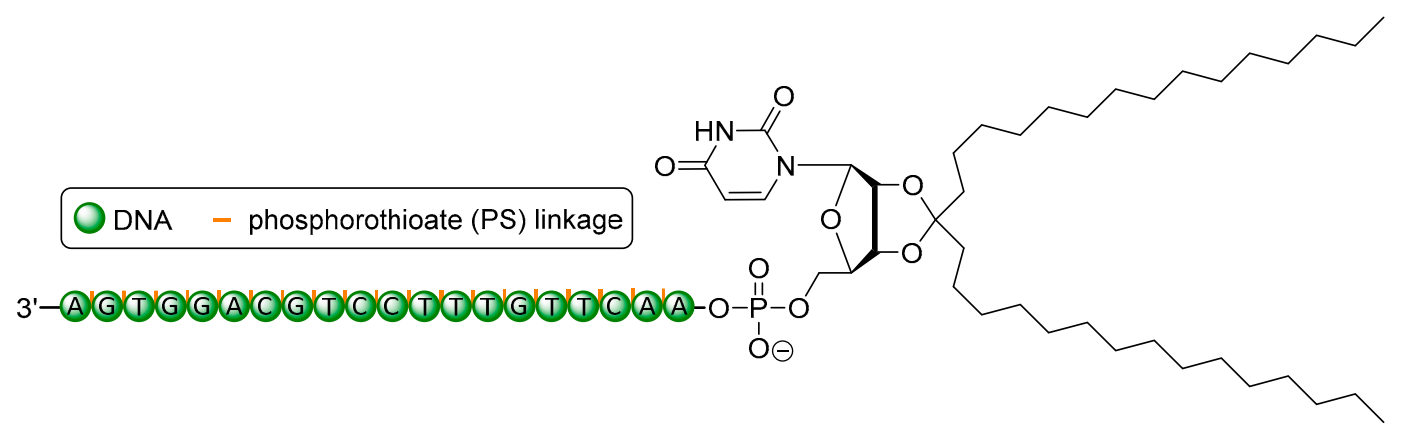

Figure 9. Structure of the ketal $\left(2^{\prime}, 3^{\prime}-\mathrm{O}-(16\right.$-hentriacontanylidene $\left.)\right)$ nucleolipid-conjugated ASO for the silencing of cancer-related expression of TCTP.

\section{Conclusions}

In summary, the conjugation of small molecules to oligonucleotides represents an exciting and promising approach to improve the pharmacokinetic and therefore the therapeutic limitations of ON-derived drug candidates. The attachment of small molecules to ON can furnish improved cellular uptake of the resultant conjugates as well as their enhanced endosomal release. The former can be achieved by exploitation of specific receptor interactions or by conjugation of the ON with lipophilic chemical entities. The latter represents an opportunity to overcome one of the main hurdles in the 
development of potent therapeutic $\mathrm{ON}$, i.e., an efficient escape from the endosomal machinery into the cytosol. In comparison to drug formulations with transfecting agents, the conjugation of ON with small molecule-derived targeting units has the potential to afford 'self-delivery' of the conjugates, thus avoiding the use of potentially toxic transfecting agents. Hence, the development of ON-small molecule conjugates should be considered a therapeutic principle with a promising future, and further innovations in this field can be anticipated.

Author Contributions: Conceptualization, M.H. and C.D.; writing-original draft preparation, M.H.; writing-review and editing, M.H. and C.D.; funding acquisition, C.D. All authors have read and agreed to the published version of the manuscript.

Funding: Our own research on oligonucleotide conjugates is funded by the Deutsche Forschungsgemeinschaft, grant DU 1095/6-1. The APC was funded by Saarland University.

Conflicts of Interest: The authors declare no conflict of interest. The funders had no role in the writing of the manuscript.

\section{References}

1. Zamecnik, P.C.; Stephenson, M.L. Inhibition of Rous sarcoma virus replication and cell transformation by a specific oligodeoxynucleotide. Proc. Natl. Acad. Sci. USA 1978, 75, 280-284. [CrossRef] [PubMed]

2. Delihas, N.; Rokita, S.E.; Zheng, P. Natural antisense RNA/target RNA interactions: Possible models for antisense oligonucleotide drug design. Nat. Biotechnol. 1997, 15, 751-753. [CrossRef] [PubMed]

3. Sokolosky, M.L.; Wargovich, M.J. Homeostatic imbalance and colon cancer: The dynamic epigenetic interplay of inflammation, environmental toxins, and chemopreventive plant compounds. Front. Oncol. 2012, 2, 57. [CrossRef]

4. Ramocki, M.B.; Zoghbi, H.Y. Failure of neuronal homeostasis results in common neuropsychiatric phenotypes. Nature 2008, 455, 912-918. [CrossRef]

5. Kotas, M.E.; Medzhitov, R. Homeostasis, inflammation, and disease susceptibility. Cell 2015, 160, 816-827. [CrossRef]

6. Chaudhuri, T.K.; Paul, S. Protein-misfolding diseases and chaperone-based therapeutic approaches. FEBS J. 2006, 273, 1331-1349. [CrossRef] [PubMed]

7. Smith, C.I.E.; Zain, R. Therapeutic Oligonucleotides: State of the Art. Annu. Rev. Pharmacol. Toxicol. 2019, 59, 605-630. [CrossRef] [PubMed]

8. Jain, M.L.; Bruice, P.Y.; Szabó, I.E.; Bruice, T.C. Incorporation of Positively Charged Linkages into DNA and RNA Backbones: A Novel Strategy for Antigene and Antisense Agents. Chem. Rev. 2012, 112, 1284-1309. [CrossRef] [PubMed]

9. Mahato, R.I.; Cheng, K.; Guntaka, R.V. Modulation of gene expression by antisense and antigene oligodeoxynucleotides and small interfering RNA. Expert Opin. Drug Deliv. 2005, 2, 3-28. [CrossRef]

10. Hélène, C.; Toulmé, J.-J. Specific regulation of gene expression by antisense, sense and antigene nucleic acids. Biochim. Biophys. Acta Gene Struct. Expr. 1990, 1049, 99-125. [CrossRef]

11. Aartsma-Rus, A.; van Vliet, L.; Hirschi, M.; Janson, A.A.M.; Heemskerk, H.; de Winter, C.L.; de Kimpe, S.; van Deutekom, J.C.T.; 't Hoen, P.A.C.; van Ommen, G.-J.B. Guidelines for Antisense Oligonucleotide Design and Insight Into Splice-modulating Mechanisms. Mol. Ther. 2009, 17, 548-553. [CrossRef] [PubMed]

12. Crooke, S.T. Molecular Mechanisms of Antisense Oligonucleotides. Nucleic Acid Ther. 2017, 27, 70-77. [CrossRef] [PubMed]

13. Liang, X.-H.; Sun, H.; Nichols, J.G.; Crooke, S.T. RNase H1-Dependent Antisense Oligonucleotides Are Robustly Active in Directing RNA Cleavage in Both the Cytoplasm and the Nucleus. Mol. Ther. 2017, 25, 2075-2092. [CrossRef] [PubMed]

14. Kurreck, J. Design of antisense oligonucleotides stabilized by locked nucleic acids. Nucleic Acids Res. 2002, 30, 1911-1918. [CrossRef] [PubMed]

15. Frieden, M. Expanding the design horizon of antisense oligonucleotides with alpha-L-LNA. Nucleic Acids Res. 2003, 31, 6365-6372. [CrossRef] [PubMed] 
16. Grünweller, A.; Wyszko, E.; Bieber, B.; Jahnel, R.; Erdmann, V.A.; Kurreck, J. Comparison of different antisense strategies in mammalian cells using locked nucleic acids, 2'-O-methyl RNA, phosphorothioates and small interfering RNA. Nucleic Acids Res. 2003, 31, 3185-3193. [CrossRef]

17. Eckstein, F. Phosphorothioates, Essential Components of Therapeutic Oligonucleotides. Nucleic Acid Ther. 2014, 24, 374-387. [CrossRef]

18. Østergaard, M.E.; De Hoyos, C.L.; Wan, W.B.; Shen, W.; Low, A.; Berdeja, A.; Vasquez, G.; Murray, S.; Migawa, M.T.; Liang, X.; et al. Understanding the effect of controlling phosphorothioate chirality in the DNA gap on the potency and safety of gapmer antisense oligonucleotides. Nucleic Acids Res. 2020, 48, 1691-1700. [CrossRef]

19. Geary, R.S.; Norris, D.; Yu, R.; Bennett, C.F. Pharmacokinetics, biodistribution and cell uptake of antisense oligonucleotides. Adv. Drug Deliv. Rev. 2015, 87, 46-51. [CrossRef]

20. Temsamani, J.; Tang, J.-Y.; Padmapriya, A.; Kubert, M.; Agrawal, S. Pharmacokinetics, Biodistribution, and Stability of Capped Oligodeoxynucleotide Phosphorothioates in Mice. Antisense Res. Dev. 1993, 3, $277-284$. [CrossRef]

21. Miller, C.M.; Donner, A.J.; Blank, E.E.; Egger, A.W.; Kellar, B.M.; Østergaard, M.E.; Seth, P.P.; Harris, E.N. Stabilin-1 and Stabilin-2 are specific receptors for the cellular internalization of phosphorothioate-modified antisense oligonucleotides (ASOs) in the liver. Nucleic Acids Res. 2016, 44, 2782-2794. [CrossRef] [PubMed]

22. Perry, C.M.; Barman Balfour, J.A. Fomivirsen. Drugs 1999, 57, 375-380. [CrossRef] [PubMed]

23. Wong, E.; Goldberg, T. Mipomersen (Kynamro): A novel antisense oligonucleotide inhibitor for the management of homozygous familial hypercholesterolemia. Pharm. Ther. 2014, 39, 119-122.

24. Hang, J.; Wan, R.; Yan, C.; Shi, Y. Structural basis of pre-mRNA splicing. Science 2015, 349, 1191-1198. [CrossRef]

25. Bauman, J.; Jearawiriyapaisarn, N.; Kole, R. Therapeutic Potential of Splice-Switching Oligonucleotides. Oligonucleotides 2009, 19,1-13. [CrossRef]

26. Chorev, M.; Carmel, L. The Function of Introns. Front. Genet. 2012, 3, 55. [CrossRef] [PubMed]

27. Wahl, M.C.; Will, C.L.; Lührmann, R. The Spliceosome: Design Principles of a Dynamic RNP Machine. Cell 2009, 136, 701-718. [CrossRef]

28. Black, D.L. Mechanisms of Alternative Pre-Messenger RNA Splicing. Annu. Rev. Biochem. 2003, 72, 291-336. [CrossRef]

29. Blencowe, B.J. Exonic splicing enhancers: Mechanism of action, diversity and role in human genetic diseases. Trends Biochem. Sci. 2000, 25, 106-110. [CrossRef]

30. Dominski, Z.; Kole, R. Restoration of correct splicing in thalassemic pre-mRNA by antisense oligonucleotides. Proc. Natl. Acad. Sci. USA 1993, 90, 8673-8677. [CrossRef]

31. Havens, M.A.; Hastings, M.L. Splice-switching antisense oligonucleotides as therapeutic drugs. Nucleic Acids Res. 2016, 44, 6549-6563. [CrossRef] [PubMed]

32. FDA Approves First Drug for Spinal Muscular Atrophy | FDA. Available online: https://www.fda.gov/news -events/press-announcements/fda-approves-first-drug-spinal-muscular-atrophy (accessed on 28 April 2020).

33. Ottesen, E.W. ISS-N1 makes the first FDA-approved drug for spinal muscular atrophy. Transl. Neurosci. 2017, 8, 1-6. [CrossRef]

34. FDA Grants Accelerated Approval to First Targeted Treatment for Rare Duchenne Muscular Dystrophy Mutation | FDA. Available online: https://www.fda.gov/news-events/press-announcements/fda-grants-acc elerated-approval-first-targeted-treatment-rare-duchenne-muscular-dystrophy-mutation (accessed on 14 April 2020).

35. Muntoni, F.; Frank, D.E.; Morgan, J.; Domingos, J.; Schnell, F.J.; Dickson, G.; Popplewell, L.; Guglieri, M.; Seferian, A.; Monforte, M.; et al. Golodirsen induces exon skipping leading to sarcolemmal dystrophin expression in patients with genetic mutations amenable to exon 53 skipping. Neuromuscul. Disord. 2018, 28, 5-43. [CrossRef]

36. FDA Grants Accelerated Approval to First Drug for Duchenne Muscular Dystrophy | FDA. Available online: https://www.fda.gov/news-events/press-announcements/fda-grants-accelerated-approval-first-d rug-duchenne-muscular-dystrophy (accessed on 14 April 2020).

37. Lim, K.R.; Maruyama, R.; Yokota, T. Eteplirsen in the treatment of Duchenne muscular dystrophy. Drug Des. Devel. Ther. 2017, 11, 533-545. [CrossRef] 
38. Kim, J.; Hu, C.; Moufawad El Achkar, C.; Black, L.E.; Douville, J.; Larson, A.; Pendergast, M.K.; Goldkind, S.F.; Lee, E.A.; Kuniholm, A.; et al. Patient-Customized Oligonucleotide Therapy for a Rare Genetic Disease. N. Engl. J. Med. 2019, 381, 1644-1652. [CrossRef] [PubMed]

39. Mello, C.C.; Conte, D. Revealing the world of RNA interference. Nature 2004, 431, 338-342. [CrossRef]

40. Kurreck, J. RNA Interference: From Basic Research to Therapeutic Applications. Angew. Chem. Int. Ed. 2009, 48, 1378-1398. [CrossRef]

41. Haasnoot, J.; Westerhout, E.M.; Berkhout, B. RNA interference against viruses: Strike and counterstrike. Nat. Biotechnol. 2007, 25, 1435-1443. [CrossRef]

42. He, L.; Hannon, G.J. MicroRNAs: Small RNAs with a big role in gene regulation. Nat. Rev. Genet. 2004, 5, 522-531. [CrossRef]

43. Reynolds, A. Induction of the interferon response by siRNA is cell type- and duplex length-dependent. $R N A$ 2006, 12, 988-993. [CrossRef]

44. Pratt, A.J.; MacRae, I.J. The RNA-induced Silencing Complex: A Versatile Gene-silencing Machine. J. Biol. Chem. 2009, 284, 17897-17901. [CrossRef] [PubMed]

45. Rand, T.A.; Ginalski, K.; Grishin, N.V.; Wang, X. Biochemical identification of Argonaute 2 as the sole protein required for RNA-induced silencing complex activity. Proc. Natl. Acad. Sci. USA 2004, 101, 14385-14389. [CrossRef] [PubMed]

46. Addepalli,H.; Meena; Peng, C.G.; Wang, G.; Fan, Y.; Charisse, K.; Jayaprakash, K.N.; Rajeev, K.G.; Pandey, R.K.; Lavine, G.; et al. Modulation of thermal stability can enhance the potency of siRNA. Nucleic Acids Res. 2010, 38, 7320-7331. [CrossRef] [PubMed]

47. Hernández, A.R.; Peterson, L.W.; Kool, E.T. Steric restrictions of RISC in RNA interference identified with size-expanded RNA nucleobases. ACS Chem. Biol. 2012, 7, 1454-1461. [CrossRef]

48. Rand, T.A.; Petersen, S.; Du, F.; Wang, X. Argonaute2 Cleaves the Anti-Guide Strand of siRNA during RISC Activation. Cell 2005, 123, 621-629. [CrossRef]

49. Kurreck, J. siRNA Efficiency: Structure or Sequence-That Is the Question. J. Biomed. Biotechnol. 2006, 2006, 1-7. [CrossRef]

50. Jackson, A.L. Position-specific chemical modification of siRNAs reduces "off-target" transcript silencing. RNA 2006, 12, 1197-1205. [CrossRef]

51. Salim, L.; Islam, G.; Desaulniers, J.-P. Targeted delivery and enhanced gene-silencing activity of centrally modified folic acid-siRNA conjugates. Nucleic Acids Res. 2020, 48, 75-85. [CrossRef]

52. Efthymiou, T.C.; Peel, B.; Huynh, V.; Desaulniers, J.-P. Evaluation of siRNAs that contain internal variable-length spacer linkages. Bioorg. Med. Chem. Lett. 2012, 22, 5590-5594. [CrossRef]

53. Desaulniers, J.-P.; Hagen, G.; Anderson, J.; McKim, C.; Roberts, B. Effective gene-silencing of siRNAs that contain functionalized spacer linkages within the central region. RSC Adv. 2017, 7, 3450-3454. [CrossRef]

54. Kumar, P.; Degaonkar, R.; Guenther, D.C.; Abramov, M.; Schepers, G.; Capobianco, M.; Jiang, Y.; Harp, J.; Kaittanis, C.; Janas, M.M.; et al. Chimeric siRNAs with chemically modified pentofuranose and hexopyranose nucleotides: Altritol-nucleotide (ANA) containing GalNAc-siRNA conjugates: In vitro and in vivo RNAi activity and resistance to $5^{\prime}$-exonuclease. Nucleic Acids Res. 2020, 48, 4028-4040. [CrossRef] [PubMed]

55. Durand, A.; Brown, T. Synthesis and Properties of Oligonucleotides Containing a Cholesterol Thymidine Monomer. Nucleosides Nucleotides Nucleic Acids 2007, 26, 785-794. [CrossRef] [PubMed]

56. Nakajima, M.; Kasuya, T.; Yokota, S.; Onishi, R.; Ikehara, T.; Kugimiya, A.; Watanabe, A. Gene Silencing Activity and Hepatic Accumulation of Antisense Oligonucleotides Bearing Cholesterol-Conjugated Thiono Triester at the Gap Region. Nucleic Acid Ther. 2017, 27, 232-237. [CrossRef] [PubMed]

57. FDA Approves First-of-Its Kind Targeted RNA-Based Therapy to Treat a RARE disease | FDA. Available online: https://www.fda.gov/news-events/press-announcements/fda-approves-first-its-kind-targeted-rna -based-therapy-treat-rare-disease (accessed on 29 April 2020).

58. Yang, J. Patisiran for the treatment of hereditary transthyretin-mediated amyloidosis. Expert Rev. Clin. Pharmacol. 2019, 12, 95-99. [CrossRef]

59. NCT03397121 Trial to Evaluate the Effect of Inclisiran Treatment on Low Density Lipoprotein Cholesterol (LDL-C) in Subjects with Heterozygous Familial Hypercholesterolemia (HeFH). Available online: https: //www.clinicaltrials.gov/ct2/show/NCT03397121 (accessed on 29 April 2020). 
60. Raal, F.J.; Kallend, D.; Ray, K.K.; Turner, T.; Koenig, W.; Wright, R.S.; Wijngaard, P.L.J.; Curcio, D.; Jaros, M.J.; Leiter, L.A.; et al. Inclisiran for the Treatment of Heterozygous Familial Hypercholesterolemia. N. Engl. J. Med. 2020, 382, 1520-1530. [CrossRef]

61. FDA Approves First Drug to Treat Rare Metabolic Disorder | FDA. Available online: https://www.fda.go v/news-events/press-announcements/fda-approves-first-drug-treat-rare-metabolic-disorder (accessed on 9 December 2020).

62. First Treatment for Rare Condition Primary Hyperoxaluria Type 1 | European Medicines Agency. Available online: https://www.ema.europa.eu/en/news/first-treatment-rare-condition-primary-hyperoxaluri a-type-1 (accessed on 9 December 2020).

63. EU/3/16/1637 | European Medicines Agency. Available online: https://www.ema.europa.eu/en/medicines/h uman/orphan-designations/eu3161637 (accessed on 9 December 2020).

64. Cochat, P.; Deloraine, A.; Rotily, M.; Olive, F.; Liponski, I.; Deries, N. Epidemiology of primary hyperoxaluria type 1. Nephrol. Dial. Transplant. 1995, 10,3-7. [CrossRef]

65. Kletzmayr, A.; Ivarsson, M.E.; Leroux, J.-C. Investigational Therapies for Primary Hyperoxaluria. Bioconjugate Chem. 2020, 31, 1696-1707. [CrossRef]

66. Saw, P.E.; Song, E.-W. siRNA therapeutics: A clinical reality. Sci. China Life Sci. 2020, 63, 485-500. [CrossRef]

67. Sharma, V.K.; Rungta, P.; Prasad, A.K. Nucleic acid therapeutics: Basic concepts and recent developments. RSC Adv. 2014, 4, 16618-16631. [CrossRef]

68. Juliano, R.; Bauman, J.; Kang, H.; Ming, X. Biological Barriers to Therapy with Antisense and siRNA Oligonucleotides. Mol. Pharm. 2009, 6, 686-695. [CrossRef]

69. Eckstein, F. Phosphorothioate Oligodeoxynucleotides: What Is Their Origin and What Is Unique About Them? Antisense Nucleic Acid Drug Dev. 2000, 10, 117-121. [CrossRef] [PubMed]

70. Godfrey, C.; Desviat, L.R.; Smedsrød, B.; Piétri-Rouxel, F.; Denti, M.A.; Disterer, P.; Lorain, S.; Nogales-Gadea, G.; Sardone, V.; Anwar, R.; et al. Delivery is key: Lessons learnt from developing splice-switching antisense therapies. EMBO Mol. Med. 2017, 9, 545-557. [CrossRef] [PubMed]

71. Juliano, R.L. The delivery of therapeutic oligonucleotides. Nucleic Acids Res. 2016, 44, 6518-6548. [CrossRef] [PubMed]

72. Knouse, K.W.; DeGruyter, J.N.; Schmidt, M.A.; Zheng, B.; Vantourout, J.C.; Kingston, C.; Mercer, S.E.; Mcdonald, I.M.; Olson, R.E.; Zhu, Y.; et al. Unlocking P(V): Reagents for chiral phosphorothioate synthesis. Science 2018, 361, 1234-1238. [CrossRef] [PubMed]

73. Srinivasan, S.K.; Tewary, H.K.; Iversen, P.L. Characterization of Binding Sites, Extent of Binding, and Drug Interactions of Oligonucleotides with Albumin. Antisense Res. Dev. 1995, 5, 131-139. [CrossRef] [PubMed]

74. Liang, X.-H.; Shen, W.; Sun, H.; Kinberger, G.A.; Prakash, T.P.; Nichols, J.G.; Crooke, S.T. Hsp90 protein interacts with phosphorothioate oligonucleotides containing hydrophobic 2 '-modifications and enhances antisense activity. Nucleic Acids Res. 2016, 44, 3892-3907. [CrossRef]

75. Agrawal, S.; Temsamani, J.; Tang, J.Y. Pharmacokinetics, biodistribution, and stability of oligodeoxynucleotide phosphorothioates in mice. Proc. Natl. Acad. Sci. USA 1991, 88, 7595-7599. [CrossRef]

76. Iannitti, T.; Morales-Medina, J.; Palmieri, B. Phosphorothioate Oligonucleotides: Effectiveness and Toxicity. Curr. Drug Targets 2014, 15, 663-673. [CrossRef]

77. Summerton, J.; Weller, D. Morpholino Antisense Oligomers: Design, Preparation, and Properties. Antisense Nucleic Acid Drug Dev. 1997, 7, 187-195. [CrossRef]

78. Meng, M.; Ducho, C. Oligonucleotide analogues with cationic backbone linkages. Beilstein J. Org. Chem. 2018, 14, 1293-1308. [CrossRef]

79. Schmidtgall, B.; Spork, A.P.; Wachowius, F.; Höbartner, C.; Ducho, C. Synthesis and properties of DNA oligonucleotides with a zwitterionic backbone structure. Chem. Commun. 2014, 50, 13742-13745. [CrossRef]

80. Schmidtgall, B.; Höbartner, C.; Ducho, C. NAA-modified DNA oligonucleotides with zwitterionic backbones: Stereoselective synthesis of A-T phosphoramidite building blocks. Beilstein J. Org. Chem. 2015, 11, 50-60. [CrossRef] [PubMed]

81. Meng, M.; Schmidtgall, B.; Ducho, C. Enhanced Stability of DNA Oligonucleotides with Partially Zwitterionic Backbone Structures in Biological Media. Molecules 2018, 23, 2941. [CrossRef] [PubMed]

82. Zhao, X.-L.; Chen, B.-C.; Han, J.-C.; Wei, L.; Pan, X.-B. Delivery of cell-penetrating peptide-peptide nucleic acid conjugates by assembly on an oligonucleotide scaffold. Sci. Rep. 2015, 5, 17640. [CrossRef] 
83. Gupta, A.; Mishra, A.; Puri, N. Peptide nucleic acids: Advanced tools for biomedical applications. J. Biotechnol. 2017, 259, 148-159. [CrossRef] [PubMed]

84. Summerton, J. Morpholino antisense oligomers: The case for an RNase H-independent structural type. Biochim. Biophys. Acta Gene Struct. Expr. 1999, 1489, 141-158. [CrossRef]

85. Moulton, J.D. Guide for Morpholino Users: Toward Therapeutics. J. Drug Discov. Dev. Deliv. 2016, 3, 1023-1035.

86. Draper, B.W.; Morcos, P.A.; Kimmel, C.B. Inhibition of zebrafish $f g f 8$ pre-mRNA splicing with morpholino oligos: A quantifiable method for gene knockdown. Genesis 2001, 30, 154-156. [CrossRef]

87. Huziak, R.M.; Barofsky, E.; Barofsky, D.F.; Weller, D.L.; Huang, S.-B.; Weller, D.D. Resistance of Morpholino Phosphorodiamidate Oligomers to Enzymatic Degradation. Antisense Nucleic Acid Drug Dev. 1996, 6, 267-272. [CrossRef]

88. Viola, H.M.; Johnstone, V.P.A.; Adams, A.M.; Fletcher, S.; Hool, L.C. A Morpholino Oligomer Therapy Regime That Restores Mitochondrial Function and Prevents mdx Cardiomyopathy. JACC Basic Transl. Sci. 2018, 3, 391-402. [CrossRef]

89. Campbell, M.A.; Wengel, J. Locked vs. unlocked nucleic acids (LNA vs. UNA): Contrasting structures work towards common therapeutic goals. Chem. Soc. Rev. 2011, 40, 5680-5689. [CrossRef] [PubMed]

90. Plavec, J.; Thibaudeau, C.; Chattopadhyaya, J. How Does the 2'-Hydroxy Group Drive the Pseudorotational Equilibrium in Nucleoside and Nucleotide by the Tuning of the 3'-Gauche Effect? J. Am. Chem. Soc. 1994, 116, 6558-6560. [CrossRef]

91. Nielsen, K.E.; Rasmussen, J.; Kumar, R.; Wengel, J.; Jacobsen, J.P.; Petersen, M. NMR Studies of Fully Modified Locked Nucleic Acid (LNA) Hybrids: Solution Structure of an LNA:RNA Hybrid and Characterization of an LNA:DNA Hybrid. Bioconjugate Chem. 2004, 15, 449-457. [CrossRef] [PubMed]

92. Singh, S.K.; Koshkin, A.A.; Wengel, J.; Nielsen, P. LNA (locked nucleic acids): Synthesis and high-affinity nucleic acid recognition. Chem. Commun. 1998, 455-456. [CrossRef]

93. Koshkin, A.A.; Singh, S.K.; Nielsen, P.; Rajwanshi, V.K.; Kumar, R.; Meldgaard, M.; Olsen, C.E.; Wengel, J. LNA (Locked Nucleic Acids): Synthesis of the adenine, cytosine, guanine, 5-methylcytosine, thymine and uracil bicyclonucleoside monomers, oligomerisation, and unprecedented nucleic acid recognition. Tetrahedron 1998, 54, 3607-3630. [CrossRef]

94. Frieden, M.; Hansen, H.F.; Koch, T. Nuclease Stability of LNA Oligonucleotides and LNA-DNA Chimeras. Nucleosides Nucleotides Nucleic Acids 2003, 22, 1041-1043. [CrossRef]

95. Monia, B.P.; Lesnik, E.A.; Gonzalez, C.; Lima, W.F.; McGee, D.; Guinosso, C.J.; Kawasaki, A.M.; Cook, P.D.; Freier, S.M. Evaluation of 2'-modified oligonucleotides containing 2 '-deoxy gaps as antisense inhibitors of gene expression. J. Biol. Chem. 1993, 268, 14514-14522.

96. Martin, P. Ein neuer Zugang zu 2'-O-Alkylribonucleosiden und Eigenschaften deren Oligonucleotide. Helv. Chim. Acta 1995, 78, 486-504. [CrossRef]

97. Egli, M.; Minasov, G.; Tereshko, V.; Pallan, P.S.; Teplova, M.; Inamati, G.B.; Lesnik, E.A.; Owens, S.R.; Ross, B.S.; Prakash, T.P.; et al. Probing the influence of stereoelectronic effects on the biophysical properties of oligonucleotides: Comprehensive analysis of the RNA affinity, nuclease resistance, and crystal structure of ten 2'-O-ribonucleic acid modifications. Biochemistry 2005, 44, 9045-9057. [CrossRef]

98. Teplova, M.; Minasov, G.; Tereshko, V.; Inamati, G.B.; Cook, P.D.; Manoharan, M.; Egli, M. Crystal structure and improved antisense properties of 2'-O-(2-methoxyethyl)-RNA. Nat. Struct. Biol. 1999, 6, 535-539.

99. Tereshko, V.; Portmann, S.; Tay, E.C.; Martin, P.; Natt, F.; Altmann, K.-H.; Egli, M. Correlating Structure and Stability of DNA Duplexes with Incorporated 2'-O-Modified RNA Analogues. Biochemistry 1998, 37, 10626-10634. [CrossRef] [PubMed]

100. Pallan, P.S.; Allerson, C.R.; Berdeja, A.; Seth, P.P.; Swayze, E.E.; Prakash, T.P.; Egli, M. Structure and nuclease resistance of $2^{\prime}, 4^{\prime}$-constrained 2'-O-methoxyethyl (cMOE) and 2'-O-ethyl (cEt) modified DNAs. Chem. Commun. 2012, 48, 8195-8197. [CrossRef] [PubMed]

101. Freier, S. The ups and downs of nucleic acid duplex stability: Structure-stability studies on chemically-modified DNA:RNA duplexes. Nucleic Acids Res. 1997, 25, 4429-4443. [CrossRef] [PubMed]

102. Morrissey, D.V.; Lockridge, J.A.; Shaw, L.; Blanchard, K.; Jensen, K.; Breen, W.; Hartsough, K.; Machemer, L.; Radka, S.; Jadhav, V.; et al. Potent and persistent in vivo anti-HBV activity of chemically modified siRNAs. Nat. Biotechnol. 2005, 23, 1002-1007. [CrossRef] [PubMed] 
103. Martin-Pintado, N.; Deleavey, G.F.; Portella, G.; Campos-Olivas, R.; Orozco, M.; Damha, M.J.; González, C. Backbone FC-H...O Hydrogen Bonds in 2'F-Substituted Nucleic Acids. Angew. Chem. Int. Ed. 2013, 52, 12065-12068. [CrossRef] [PubMed]

104. Pallan, P.S.; Greene, E.M.; Jicman, P.A.; Pandey, R.K.; Manoharan, M.; Rozners, E.; Egli, M. Unexpected origins of the enhanced pairing affinity of 2'-fluoro-modified RNA. Nucleic Acids Res. 2011, 39, 3482-3495. [CrossRef] [PubMed]

105. Kawasaki, A.M.; Casper, M.D.; Freier, S.M.; Lesnik, E.A.; Zounes, M.C.; Cummins, L.L.; Gonzalez, C.; Cook, P.D. Uniformly modified 2'-deoxy-2'-fluoro-phosphorothioate oligonucleotides as nuclease-resistant antisense compounds with high affinity and specificity for RNA targets. J. Med. Chem. 1993, 36, 831-841. [CrossRef]

106. Manoharan, M.; Akinc, A.; Pandey, R.K.; Qin, J.; Hadwiger, P.; John, M.; Mills, K.; Charisse, K.; Maier, M.A.; Nechev, L.; et al. Unique Gene-Silencing and Structural Properties of 2'-Fluoro-Modified siRNAs. Angew. Chem. Int. Ed. 2011, 50, 2284-2288. [CrossRef]

107. Sipa, K.; Sochacka, E.; Kazmierczak-Baranska, J.; Maszewska, M.; Janicka, M.; Nowak, G.; Nawrot, B. Effect of base modifications on structure, thermodynamic stability, and gene silencing activity of short interfering RNA. RNA 2007, 13, 1301-1316. [CrossRef]

108. Bramsen, J.B.; Laursen, M.B.; Nielsen, A.F.; Hansen, T.B.; Bus, C.; Langkjær, N.; Babu, B.R.; Højland, T.; Abramov, M.; Van Aerschot, A.; et al. A large-scale chemical modification screen identifies design rules to generate siRNAs with high activity, high stability and low toxicity. Nucleic Acids Res. 2009, 37, 2867-2881. [CrossRef]

109. Herdewijn, P. Heterocyclic Modifications of Oligonucleotides and Antisense Technology. Antisense Nucleic Acid Drug Dev. 2000, 10, 297-310. [CrossRef] [PubMed]

110. Peacock, H.; Kannan, A.; Beal, P.A.; Burrows, C.J. Chemical Modification of siRNA Bases To Probe and Enhance RNA Interference. J. Org. Chem. 2011, 76, 7295-7300. [CrossRef] [PubMed]

111. Wan, W.B.; Seth, P.P. The Medicinal Chemistry of Therapeutic Oligonucleotides. J. Med. Chem. 2016, 59, 9645-9667. [CrossRef] [PubMed]

112. Prakash, T.P. An Overview of Sugar-Modified Oligonucleotides for Antisense Therapeutics. Chem. Biodivers. 2011, 8, 1616-1641. [CrossRef]

113. Chan, J.H.; Lim, S.; Wong, W.F. Antisense Oligonucleotides: From design to therapeutical application. Clin. Exp. Pharmacol. Physiol. 2006, 33, 533-540. [CrossRef]

114. Deleavey, G.F.; Damha, M.J. Designing Chemically Modified Oligonucleotides for Targeted Gene Silencing. Chem. Biol. 2012, 19, 937-954. [CrossRef]

115. Chiu, Y.-L.; Rana, T.M. siRNA function in RNAi: A chemical modification analysis. RNA 2003, 9, $1034-1048$. [CrossRef]

116. Fazakerley, G.V.; Sowers, L.C.; Eritja, R.; Kaplan, B.E.; Goodman, M.F. Structural and Dynamic Properties of a Bromouracil-Adenine Base Pair in DNA Studied by Proton NMR. J. Biomol. Struct. Dyn. 1987, 5, 639-650. [CrossRef]

117. Wansink, D.G.; Nelissen, R.L.H.; de Jong, L. In vitro splicing of pre-mRNA containing bromouridine. Mol. Biol. Rep. 1994, 19, 109-113. [CrossRef]

118. Sanghvi, Y.S.; Hoke, G.D.; Zounes, M.C.; Freier, S.M.; Martin, J.F.; Chan, H.; Acevedo, O.L.; Ecker, D.J.; Mirabelli, C.K.; Crooke, S.T.; et al. Synthesis and Biological Evaluation of Antisense Oligonucleotides Containing Modified Pyrimidines. Nucleosides Nucleotides 1991, 10, 345-346. [CrossRef]

119. Theruvathu, J.A.; Yin, Y.W.; Pettitt, B.M.; Sowers, L.C. Comparison of the Structural and Dynamic Effects of 5-Methylcytosine and 5-Chlorocytosine in a CpG Dinucleotide Sequence. Biochemistry 2013, 52, 8590-8598. [CrossRef] [PubMed]

120. Terrazas, M.; Kool, E.T. RNA major groove modifications improve siRNA stability and biological activity. Nucleic Acids Res. 2009, 37, 346-353. [CrossRef] [PubMed]

121. Fryxell, K.J.; Zuckerkandl, E. Cytosine Deamination Plays a Primary Role in the Evolution of Mammalian Isochores. Mol. Biol. Evol. 2000, 17, 1371-1383. [CrossRef] [PubMed]

122. Sági, J.; Szemzö, A.; Ötvös, L.; Vorlíčková, M.; Kypr, J. Destabilization of the duplex and the high-salt Z-form of poly(dG-methyl5dC) by substitution of ethyl for the 5-methyl group. Int. J. Biol. Macromol. 1991, 13, 329-336. [CrossRef] 
123. Froehler, B.C.; Wadwani, S.; Terhorst, T.J.; Gerrard, S.R. Oligodeoxynucleotides containing C-5 propyne analogs of 2'-deoxyuridine and 2'-deoxycytidine. Tetrahedron Lett. 1992, 33, 5307-5310. [CrossRef]

124. Wagner, R.; Matteucci, M.; Lewis, J.; Gutierrez, A.; Moulds, C.; Froehler, B. Antisense gene inhibition by oligonucleotides containing C-5 propyne pyrimidines. Science 1993, 260, 1510-1513. [CrossRef]

125. Gutierrez, A.J.; Terhorst, T.J.; Matteucci, M.D.; Froehler, B.C. 5-Heteroaryl-2'-deoxyuridine Analogs. Synthesis and Incorporation into High-Affinity Oligonucleotides. J. Am. Chem. Soc. 1994, 116, 5540-5544. [CrossRef]

126. Lima, W.F.; Nichols, J.G.; Wu, H.; Prakash, T.P.; Migawa, M.T.; Wyrzykiewicz, T.K.; Bhat, B.; Crooke, S.T. Structural Requirements at the Catalytic Site of the Heteroduplex Substrate for Human RNase H1 Catalysis. J. Biol. Chem. 2004, 279, 36317-36326. [CrossRef]

127. Agris, P.F.; Sierzputowska-Gracz, H.; Smith, W.; Malkiewicz, A.; Sochacka, E.; Nawrot, B. Thiolation of uridine carbon-2 restricts the motional dynamics of the transfer RNA wobble position nucleoside. J. Am. Chem. Soc. 1992, 114, 2652-2656. [CrossRef]

128. Ishikawa, T.; Yoneda, F.; Tanaka, K.; Fuji, K. Synthesis and properties of oligothymidylate containing sulfur-modified thymidine: Effect of thiation of pyrimidine ring on the thermostability and conformation of the duplex. Bioorg. Med. Chem. Lett. 1991, 1, 523-526. [CrossRef]

129. Sochacka, E.; Lodyga-Chruscinska, E.; Pawlak, J.; Cypryk, M.; Bartos, P.; Ebenryter-Olbinska, K.; Leszczynska, G.; Nawrot, B. C5-substituents of uridines and 2-thiouridines present at the wobble position of tRNA determine the formation of their keto-enol or zwitterionic forms-A factor important for accuracy of reading of guanosine at the $3^{\prime}$-end of the mRNA codons. Nucleic Acids Res. 2017, 45, 4825-4836. [CrossRef] [PubMed]

130. Kirnos, M.D.; Khudjakov, I.Y.; Alexandruschkina, N.I.; Vanyushin, B.F. 2-Aminoadenine is an adenine substituting for a base in S-2L cyanophage DNA. Nature 1977, 270, 369-370. [CrossRef] [PubMed]

131. Kutyavin, I.V.; Rhinehart, R.L.; Lukhtanov, E.A.; Gorn, V.V.; Meyer, R.B.; Gamper, H.B. Oligonucleotides Containing 2-Aminoadenine and 2-Thiothymine Act as Selectively Binding Complementary Agents. Biochemistry 1996, 35, 11170-11176. [CrossRef] [PubMed]

132. Gryaznov, S.; Schultz, R.G. Stabilization of DNA:DNA and DNA:RNA duplexes by substitution of 2'-deoxyadenosine with 2'-deoxy-2-aminoadenosine. Tetrahedron Lett. 1994, 35, 2489-2492. [CrossRef]

133. Ramasamy, K.S.; Zounes, M.; Gonzalez, C.; Freier, S.M.; Lesnik, E.A.; Cummins, L.L.; Griffey, R.H.; Monia, B.P.; Dan Cook, P. Remarkable enhancement of binding affinity of Heterocycle-modified DNA to DNA and RNA. Synthesis, characterization and biophysical evaluation of N2-imidazolylpropylguanine and N2-imidazolylpropyl-2-aminoadenine modified oligonucleotides. Tetrahedron Lett. 1994, 35, 215-218. [CrossRef]

134. Buhr, C. Oligodeoxynucleotides containing C-7 propyne analogs of 7-deaza-2'-deoxyguanosine and 7-deaza-2'-deoxyadenosine. Nucleic Acids Res. 1996, 24, 2974-2980. [CrossRef]

135. Peacock, H.; Fucini, R.V.; Jayalath, P.; Ibarra-Soza, J.M.; Haringsma, H.J.; Flanagan, W.M.; Willingham, A.; Beal, P.A. Nucleobase and Ribose Modifications Control Immunostimulation by a MicroRNA-122-mimetic RNA. J. Am. Chem. Soc. 2011, 133, 9200-9203. [CrossRef]

136. Manoharan, M.; Ramasamy, K.S.; Mohan, V.; Cook, P.D. Oligonucleotides bearing cationic groups: N2-(3-aminopropyl)deoxyguanosine. Synthesis, enhanced binding properties and conjugation chemistry. Tetrahedron Lett. 1996, 37, 7675-7678. [CrossRef]

137. Parton, R.G.; Richards, A.A. Lipid Rafts and Caveolae as Portals for Endocytosis: New Insights and Common Mechanisms. Traffic 2003, 4, 724-738. [CrossRef]

138. Doherty, G.J.; McMahon, H.T. Mechanisms of Endocytosis. Annu. Rev. Biochem. 2009, 78, 857-902. [CrossRef]

139. Juliano, R.L. Intracellular Trafficking and Endosomal Release of Oligonucleotides: What We Know and What We Don't. Nucleic Acid Ther. 2018, 28, 166-177. [CrossRef] [PubMed]

140. Hu, Y.-B.; Dammer, E.B.; Ren, R.-J.; Wang, G. The endosomal-lysosomal system: From acidification and cargo sorting to neurodegeneration. Transl. Neurodegener. 2015, 4, 18. [CrossRef] [PubMed]

141. Goldenring, J.R. Recycling endosomes. Curr. Opin. Cell Biol. 2015, 35, 117-122. [CrossRef] [PubMed]

142. Huotari, J.; Helenius, A. Endosome maturation. EMBO J. 2011, 30, 3481-3500. [CrossRef] [PubMed]

143. Johannes, L.; Wunder, C. Retrograde Transport: Two (or More) Roads Diverged in an Endosomal Tree? Traffic 2011, 12, 956-962. [CrossRef] [PubMed]

144. Hanson, P.I.; Cashikar, A. Multivesicular Body Morphogenesis. Annu. Rev. Cell Dev. Biol. 2012, 28, 337-362. [CrossRef] [PubMed] 
145. Russell, M.R.G.; Nickerson, D.P.; Odorizzi, G. Molecular mechanisms of late endosome morphology, identity and sorting. Curr. Opin. Cell Biol. 2006, 18, 422-428. [CrossRef]

146. Scott, C.C.; Vacca, F.; Gruenberg, J. Endosome maturation, transport and functions. Semin. Cell Dev. Biol. 2014, 31, 2-10. [CrossRef]

147. Grant, B.D.; Donaldson, J.G. Pathways and mechanisms of endocytic recycling. Nat. Rev. Mol. Cell Biol. 2009, 10, 597-608. [CrossRef]

148. Brown, M.S.; Anderson, R.G.W.; Goldstein, J.L. Recycling receptors: The round-trip itinerary of migrant membrane proteins. Cell 1983, 32, 663-667. [CrossRef]

149. Dautry-Varsat, A. Receptor-mediated endocytosis: The intracellular journey of transferrin and its receptor. Biochimie 1986, 68, 375-381. [CrossRef]

150. Onizuka, T.; Shimizu, H.; Moriwaki, Y.; Nakano, T.; Kanai, S.; Shimada, I.; Takahashi, H. NMR study of ligand release from asialoglycoprotein receptor under solution conditions in early endosomes. FEBS J. 2012, 279, 2645-2656. [CrossRef] [PubMed]

151. Luzio, J.P.; Pryor, P.R.; Bright, N.A. Lysosomes: Fusion and function. Nat. Rev. Mol. Cell Biol. 2007, 8, 622-632. [CrossRef] [PubMed]

152. Juliano, R.L.; Ming, X.; Nakagawa, O. Cellular Uptake and Intracellular Trafficking of Antisense and siRNA Oligonucleotides. Bioconjugate Chem. 2012, 23, 147-157. [CrossRef]

153. Alam, M.R.; Ming, X.; Dixit, V.; Fisher, M.; Chen, X.; Juliano, R.L. The Biological Effect of an Antisense Oligonucleotide Depends on Its Route of Endocytosis and Trafficking. Oligonucleotides 2010, 20, 103-109. [CrossRef]

154. Bijsterbosch, M. In vivo fate of phosphorothioate antisense oligodeoxynucleotides: Predominant uptake by scavenger receptors on endothelial liver cells. Nucleic Acids Res. 1997, 25, 3290-3296. [CrossRef]

155. Liang, X.; Sun, H.; Shen, W.; Crooke, S.T. Identification and characterization of intracellular proteins that bind oligonucleotides with phosphorothioate linkages. Nucleic Acids Res. 2015, 43, 2927-2945. [CrossRef]

156. Crooke, S.T.; Wang, S.; Vickers, T.A.; Shen, W.; Liang, X. Cellular uptake and trafficking of antisense oligonucleotides. Nat. Biotechnol. 2017, 35, 230-237. [CrossRef]

157. Wang, S.; Sun, H.; Tanowitz, M.; Liang, X.-H.; Crooke, S.T. Annexin A2 facilitates endocytic trafficking of antisense oligonucleotides. Nucleic Acids Res. 2016, 44, 7314-7330. [CrossRef]

158. Durymanov, M.; Reineke, J. Non-viral Delivery of Nucleic Acids: Insight Into Mechanisms of Overcoming Intracellular Barriers. Front. Pharmacol. 2018, 9, 971. [CrossRef]

159. Wang, S.; Sun, H.; Tanowitz, M.; Liang, X.; Crooke, S.T. Intra-endosomal trafficking mediated by lysobisphosphatidic acid contributes to intracellular release of phosphorothioate-modified antisense oligonucleotides. Nucleic Acids Res. 2017, 45, 5309-5322. [CrossRef] [PubMed]

160. Gilleron, J.; Querbes, W.; Zeigerer, A.; Borodovsky, A.; Marsico, G.; Schubert, U.; Manygoats, K.; Seifert, S.; Andree, C.; Stöter, M.; et al. Image-based analysis of lipid nanoparticle-mediated siRNA delivery, intracellular trafficking and endosomal escape. Nat. Biotechnol. 2013, 31, 638-646. [CrossRef] [PubMed]

161. Sahay, G.; Querbes, W.; Alabi, C.; Eltoukhy, A.; Sarkar, S.; Zurenko, C.; Karagiannis, E.; Love, K.; Chen, D.; Zoncu, R.; et al. Efficiency of siRNA delivery by lipid nanoparticles is limited by endocytic recycling. Nat. Biotechnol. 2013, 31, 653-658. [CrossRef] [PubMed]

162. Wang, H.; Tam, Y.Y.C.; Chen, S.; Zaifman, J.; van der Meel, R.; Ciufolini, M.A.; Cullis, P.R. The Niemann-Pick C1 Inhibitor NP3.47 Enhances Gene Silencing Potency of Lipid Nanoparticles Containing siRNA. Mol. Ther. 2016, 24, 2100-2108. [CrossRef] [PubMed]

163. Lindberg, S.; Regberg, J.; Eriksson, J.; Helmfors, H.; Muñoz-Alarcón, A.; Srimanee, A.; Figueroa, R.A.; Hallberg, E.; Ezzat, K.; Langel, Ü. A convergent uptake route for peptide- and polymer-based nucleotide delivery systems. J. Control. Release 2015, 206, 58-66. [CrossRef]

164. Said Hassane, F.; Abes, R.; Andaloussi, S.E.; Lehto, T.; Sillard, R.; Langel, Ü.; Lebleu, B. Insights into the cellular trafficking of splice redirecting oligonucleotides complexed with chemically modified cell-penetrating peptides. J. Control. Release 2011, 153, 163-172. [CrossRef]

165. Kubota, Y. Src transduces erythropoietin-induced differentiation signals through phosphatidylinositol 3-kinase. EMBO J. 2001, 20, 5666-5677. [CrossRef]

166. Rehman, Z.U.; Hoekstra, D.; Zuhorn, I.S. Mechanism of Polyplex- and Lipoplex-Mediated Delivery of Nucleic Acids: Real-Time Visualization of Transient Membrane Destabilization without Endosomal Lysis. ACS Nano 2013, 7, 3767-3777. [CrossRef] 
167. Degors, I.M.S.; Wang, C.; Rehman, Z.U.; Zuhorn, I.S. Carriers Break Barriers in Drug Delivery: Endocytosis and Endosomal Escape of Gene Delivery Vectors. Acc. Chem. Res. 2019, 52, 1750-1760. [CrossRef]

168. Casey, J.R.; Grinstein, S.; Orlowski, J. Sensors and regulators of intracellular pH. Nat. Rev. Mol. Cell Biol. 2010, 11, 50-61. [CrossRef]

169. Cutler, J.I.; Auyeung, E.; Mirkin, C.A. Spherical Nucleic Acids. J. Am. Chem. Soc. 2012, 134, $1376-1391$. [CrossRef] [PubMed]

170. Choi, C.H.J.; Hao, L.; Narayan, S.P.; Auyeung, E.; Mirkin, C.A. Mechanism for the endocytosis of spherical nucleic acid nanoparticle conjugates. Proc. Natl. Acad. Sci. USA 2013, 110, 7625-7630. [CrossRef] [PubMed]

171. Wu, X.A.; Choi, C.H.J.; Zhang, C.; Hao, L.; Mirkin, C.A. Intracellular Fate of Spherical Nucleic Acid Nanoparticle Conjugates. J. Am. Chem. Soc. 2014, 136, 7726-7733. [CrossRef] [PubMed]

172. Ferrer, J.R.; Wertheim, J.A.; Mirkin, C.A. Dual Toll-Like Receptor Targeting Liposomal Spherical Nucleic Acids. Bioconjugate Chem. 2019, 30, 944-951. [CrossRef] [PubMed]

173. Zhu, X.-D.; Zhuang, Y.; Ben, J.-J.; Qian, L.-L.; Huang, H.-P.; Bai, H.; Sha, J.-H.; He, Z.-G.; Chen, Q. Caveolae-dependent Endocytosis Is Required for Class A Macrophage Scavenger Receptor-mediated Apoptosis in Macrophages. J. Biol. Chem. 2011, 286, 8231-8239. [CrossRef]

174. Bitsikas, V.; Corrêa, I.R.; Nichols, B.J. Clathrin-independent pathways do not contribute significantly to endocytic flux. eLife 2014, 3, e03970. [CrossRef]

175. Kaksonen, M.; Roux, A. Mechanisms of clathrin-mediated endocytosis. Nat. Rev. Mol. Cell Biol. 2018, 19, 313-326. [CrossRef]

176. Alam, M.R.; Dixit, V.; Kang, H.; Li, Z.-B.; Chen, X.; Trejo, J.; Fisher, M.; Juliano, R.L. Intracellular delivery of an anionic antisense oligonucleotide via receptor-mediated endocytosis. Nucleic Acids Res. 2008, 36, 2764-2776. [CrossRef]

177. Ly, S.; Navaroli, D.M.; Didiot, M.-C.; Cardia, J.; Pandarinathan, L.; Alterman, J.F.; Fogarty, K.; Standley, C.; Lifshitz, L.M.; Bellve, K.D.; et al. Visualization of self-delivering hydrophobically modified siRNA cellular internalization. Nucleic Acids Res. 2017, 45, 15-25. [CrossRef]

178. Mishra, A.; Eathiraj, S.; Corvera, S.; Lambright, D.G. Structural basis for Rab GTPase recognition and endosome tethering by the $\mathrm{C} 2 \mathrm{H} 2$ zinc finger of Early Endosomal Autoantigen 1 (EEA1). Proc. Natl. Acad. Sci. USA 2010, 107, 10866-10871. [CrossRef] [PubMed]

179. Buntz, A.; Killian, T.; Schmid, D.; Seul, H.; Brinkmann, U.; Ravn, J.; Lindholm, M.; Knoetgen, H.; Haucke, V.; Mundigl, O. Quantitative fluorescence imaging determines the absolute number of locked nucleic acid oligonucleotides needed for suppression of target gene expression. Nucleic Acids Res. 2019, 47, 953-969. [CrossRef] [PubMed]

180. Juliano, R.L.; Carver, K.; Cao, C.; Ming, X. Receptors, endocytosis, and trafficking: The biological basis of targeted delivery of antisense and siRNA oligonucleotides. J. Drug Targeting 2013, 21, 27-43. [CrossRef] [PubMed]

181. Wang, S.; Allen, N.; Vickers, T.A.; Revenko, A.S.; Sun, H.; Liang, X.; Crooke, S.T. Cellular uptake mediated by epidermal growth factor receptor facilitates the intracellular activity of phosphorothioate-modified antisense oligonucleotides. Nucleic Acids Res. 2018, 46, 3579-3594. [CrossRef] [PubMed]

182. Roux, A.; Uyhazi, K.; Frost, A.; De Camilli, P. GTP-dependent twisting of dynamin implicates constriction and tension in membrane fission. Nature 2006, 441, 528-531. [CrossRef] [PubMed]

183. Hutagalung, A.H.; Novick, P.J. Role of Rab GTPases in Membrane Traffic and Cell Physiology. Physiol. Rev. 2011, 91, 119-149. [CrossRef] [PubMed]

184. Stenmark, H. Rab GTPases as coordinators of vesicle traffic. Nat. Rev. Mol. Cell Biol. 2009, 10, 513-525. [CrossRef] [PubMed]

185. Bröcker, C.; Engelbrecht-Vandré, S.; Ungermann, C. Multisubunit Tethering Complexes and Their Role in Membrane Fusion. Curr. Biol. 2010, 20, 943-952. [CrossRef]

186. Witkos, T.M.; Lowe, M. Recognition and tethering of transport vesicles at the Golgi apparatus. Curr. Opin. Cell Biol. 2017, 47, 16-23. [CrossRef]

187. Malsam, J.; Kreye, S.; Söllner, T.H. Membrane traffic in the secretory pathway. Cell. Mol. Life Sci. 2008, 65, 2814-2832. [CrossRef]

188. Kümmel, D.; Ungermann, C. Principles of membrane tethering and fusion in endosome and lysosome biogenesis. Curr. Opin. Cell Biol. 2014, 29, 61-66. [CrossRef] [PubMed] 
189. Rehman, Z.U.; Hoekstra, D.; Zuhorn, I.S. Protein kinase A inhibition modulates the intracellular routing of gene delivery vehicles in HeLa cells, leading to productive transfection. J. Control. Release 2011, 156, 76-84. [CrossRef] [PubMed]

190. Liang, X.; Sun, H.; Hsu, C.-W.; Nichols, J.G.; Vickers, T.A.; De Hoyos, C.L.; Crooke, S.T. Golgi-endosome transport mediated by M6PR facilitates release of antisense oligonucleotides from endosomes. Nucleic Acids Res. 2020, 48, 1372-1391. [CrossRef] [PubMed]

191. Johannes, L.; Popoff, V. Tracing the Retrograde Route in Protein Trafficking. Cell 2008, 135, $1175-1187$. [CrossRef] [PubMed]

192. Wang, T.; Smith, E.A.; Chapman, E.R.; Weisshaar, J.C. Lipid Mixing and Content Release in Single-Vesicle, SNARE-Driven Fusion Assay with 1-5 ms Resolution. Biophys. J. 2009, 96, 4122-4131. [CrossRef]

193. Schmidt, O.; Teis, D. The ESCRT machinery. Curr. Biol. 2012, 22, 116-120. [CrossRef]

194. Henne, W.M.; Stenmark, H.; Emr, S.D. Molecular Mechanisms of the Membrane Sculpting ESCRT Pathway. Cold Spring Harb. Perspect. Biol. 2013, 5, a016766. [CrossRef]

195. Bissig, C.; Gruenberg, J. ALIX and the multivesicular endosome: ALIX in Wonderland. Trends Cell Biol. 2014, 24, 19-25. [CrossRef]

196. Kobayashi, T.; Startchev, K.; Whitney, A.J.; Gruenberg, J. Localization of Lysobisphosphatidic Acid-Rich Membrane Domains in Late Endosomes. Biol. Chem. 2001, 382, 483-485. [CrossRef]

197. Edgar, J.R.; Eden, E.R.; Futter, C.E. Hrs- and CD63-Dependent Competing Mechanisms Make Different Sized Endosomal Intraluminal Vesicles. Traffic 2014, 15, 197-211. [CrossRef]

198. Cullis, P.R.; Kruijff, B.D. Lipid polymorphism and the functional Roles of Lipids in. Chem. Phys. Lipids 1986, 40, 127-144. [CrossRef]

199. Su, T.-P.; Su, T.-C.; Nakamura, Y.; Tsai, S.-Y. The Sigma-1 Receptor as a Pluripotent Modulator in Living Systems. Trends Pharmacol. Sci. 2016, 37, 262-278. [CrossRef] [PubMed]

200. Cobos, E.; Entrena, J.; Nieto, F.; Cendan, C.; Pozo, E. Pharmacology and Therapeutic Potential of Sigma1 Receptor Ligands. Curr. Neuropharmacol. 2009, 6, 344-366. [CrossRef] [PubMed]

201. Walker, J.M.; Bowen, W.D.; Walker, F.O.; Matsumoto, R.R.; De Costa, B.; Rice, K.C. Sigma receptors: Biology and function. Pharmacol. Rev. 1990, 42, 355-402.

202. John, C.S.; Vilner, B.J.; Geyer, B.C.; Moody, T.; Bowen, W.D. Targeting sigma receptor-binding benzamides as in vivo diagnostic and therapeutic agents for human prostate tumors. Cancer Res. 1999, 59, 4578-4583. [PubMed]

203. Vilner, B.J.; John, C.S.; Bowen, W.D. Sigma-1 and Sigma-2 Receptors Are Expressed in a Wide Variety of Human and Rodent Tumor Cell Lines. Cancer Res. 1995, 55, 408-413. [PubMed]

204. John, C.S.; Bowen, W.D.; Fisher, S.J.; Lim, B.B.; Geyer, B.C.; Vilner, B.J.; Wahl, R.L. Synthesis, in vitro pharmacologic characterization, and preclinical evaluation of $\mathrm{N}$-[2-(1'-piperidinyl)ethyl] $-3-\left[{ }^{125}\right.$ I] iodo-4-methoxybenzamide (P[ $\left.\left.{ }^{125} \mathrm{I}\right] \mathrm{MBA}\right)$ for imaging breast cancer. Nucl. Med. Biol. 1999, 26, 377-382. [CrossRef]

205. John, C.S.; Bowen, W.D.; Saga, T.; Kinuya, S.; Vilner, B.J.; Baumgold, J.; Paik, C.H.; Reba, R.C.; Neumann, R.D.; Varma, V.M. A malignant melanoma imaging agent: Synthesis, characterization, in vitro binding and biodistribution of iodine-125-(2-piperidinylaminoethyl)4-iodobenzamide. J. Nucl. Med. 1993, 34, 2169-2175.

206. Banerjee, R.; Tyagi, P.; Li, S.; Huang, L. Anisamide-targeted stealth liposomes: A potent carrier for targeting doxorubicin to human prostate cancer cells. Int. J. Cancer 2004, 112, 693-700. [CrossRef]

207. Li, S.-D.; Huang, L. Targeted Delivery of Antisense Oligodeoxynucleotide and Small Interference RNA into Lung Cancer Cells. Mol. Pharm. 2006, 3, 579-588. [CrossRef]

208. Li, S.-D.; Chen, Y.-C.; Hackett, M.J.; Huang, L. Tumor-targeted Delivery of siRNA by Self-assembled Nanoparticles. Mol. Ther. 2008, 16, 163-169. [CrossRef]

209. Lv, H.; Zhang, S.; Wang, B.; Cui, S.; Yan, J. Toxicity of cationic lipids and cationic polymers in gene delivery. J. Control. Release 2006, 114, 100-109. [CrossRef] [PubMed]

210. Mishra, V.; Bansal, K.; Verma, A.; Yadav, N.; Thakur, S.; Sudhakar, K.; Rosenholm, J. Solid Lipid Nanoparticles: Emerging Colloidal Nano Drug Delivery Systems. Pharmaceutics 2018, 10, 191. [CrossRef]

211. Qin, S.-Y.; Zhang, A.-Q.; Cheng, S.-X.; Rong, L.; Zhang, X.-Z. Drug self-delivery systems for cancer therapy. Biomaterials 2017, 112, 234-247. [CrossRef] [PubMed]

212. Altieri, D.C. Validating survivin as a cancer therapeutic target. Nat. Rev. Cancer 2003, 3, 46-54. [CrossRef] [PubMed] 
213. Li, F.; Ackermann, E.J.; Bennett, C.F.; Rothermel, A.L.; Plescia, J.; Tognin, S.; Villa, A.; Marchisio, P.C.; Altieri, D.C. Pleiotropic cell-division defects and apoptosis induced by interference with survivin function. Nat. Cell Biol. 1999, 1, 461-466. [CrossRef]

214. Alam, M.R.; Ming, X.; Nakagawa, O.; Jin, J.; Juliano, R.L. Covalent conjugation of oligonucleotides with cell-targeting ligands. Bioorg. Med. Chem. 2013, 21, 6217-6223. [CrossRef]

215. Sazani, P.; Kole, R. Therapeutic potential of antisense oligonucleotides as modulators of alternative splicing. J. Clin. Investig. 2003, 112, 481-486. [CrossRef]

216. Nakagawa, O.; Ming, X.; Huang, L.; Juliano, R.L. Targeted Intracellular Delivery of Antisense Oligonucleotides via Conjugation with Small-Molecule Ligands. J. Am. Chem. Soc. 2010, 132, 8848-8849. [CrossRef]

217. Dasargyri, A.; Hervella, P.; Christiansen, A.; Proulx, S.T.; Detmar, M.; Leroux, J.-C. Findings questioning the involvement of Sigma-1 receptor in the uptake of anisamide-decorated particles. J. Control. Release 2016, 224, 229-238. [CrossRef]

218. Ross, R.A. Anandamide and vanilloid TRPV1 receptors. Br. J. Pharmacol. 2003, 140, 790-801. [CrossRef]

219. Devane, W.; Hanus, L.; Breuer, A.; Pertwee, R.; Stevenson, L.; Griffin, G.; Gibson, D.; Mandelbaum, A.; Etinger, A.; Mechoulam, R. Isolation and structure of a brain constituent that binds to the cannabinoid receptor. Science 1992, 258, 1946-1949. [CrossRef] [PubMed]

220. Filion, M.C.; Phillips, N.C. Toxicity and immunomodulatory activity of liposomal vectors formulated with cationic lipids toward immune effector cells. Biochim. Biophys. Acta Biomembr. 1997, 1329, 345-356. [CrossRef]

221. Wood, M.J.A.; Trulzsch, B.; Abdelgany, A.; Beeson, D. Therapeutic gene silencing in the nervous system. Hum. Mol. Genet. 2003, 12, 279-284. [CrossRef] [PubMed]

222. Willibald, J.; Harder, J.; Sparrer, K.; Conzelmann, K.K.; Carell, T. Click-modified anandamide siRNA enables delivery and gene silencing in neuronal and immune cells. J. Am. Chem. Soc. 2012, 134, 12330-12333. [CrossRef] [PubMed]

223. Rakhshan, F.; Day, T.A.; Blakely, R.D.; Barker, E.L. Carrier-Mediated Uptake of the Endogenous Cannabinoid Anandamide in RBL-2H3 Cells. J. Pharmacol. Exp. Ther. 2000, 292, 960-967.

224. Facci, L.; Dal Toso, R.; Romanello, S.; Buriani, A.; Skaper, S.D.; Leon, A. Mast cells express a peripheral cannabinoid receptor with differential sensitivity to anandamide and palmitoylethanolamide. Proc. Natl. Acad. Sci. USA 1995, 92, 3376-3380. [CrossRef]

225. Coffey, G.; DeGuzman, F.; Inagaki, M.; Pak, Y.; Delaney, S.M.; Ives, D.; Betz, A.; Jia, Z.J.; Pandey, A.; Baker, D.; et al. Specific Inhibition of Spleen Tyrosine Kinase Suppresses Leukocyte Immune Function and Inflammation in Animal Models of Rheumatoid Arthritis. J. Pharmacol. Exp. Ther. 2012, 340, 350-359. [CrossRef]

226. Geahlen, R.L. Getting Syk: Spleen tyrosine kinase as a therapeutic target. Trends Pharmacol. Sci. 2014, 35, 414-422. [CrossRef]

227. Sanderson, M.P.; Gelling, S.J.; Rippmann, J.F.; Schnapp, A. Comparison of the anti-allergic activity of Syk inhibitors with optimized Syk siRNAs in FceRI-activated RBL-2H3 basophilic cells. Cell. Immunol. 2010, 262, 28-34. [CrossRef]

228. Brunner, K.; Harder, J.; Halbach, T.; Willibald, J.; Spada, F.; Gnerlich, F.; Sparrer, K.; Beil, A.; Möckl, L.; Bräuchle, C.; et al. Cell-Penetrating and Neurotargeting Dendritic siRNA Nanostructures. Angew. Chem. Int. Ed. 2015, 54, 1946-1949. [CrossRef]

229. Yang, Y.-J.; Zhao, P.-S.; Zhang, T.; Wang, H.-L.; Liang, H.-R.; Zhao, L.-L.; Wu, H.-X.; Wang, T.-C.; Yang, S.-T.; $\mathrm{Xia}, \mathrm{X} . \mathrm{Z}$. Small interfering RNAs targeting the rabies virus nucleoprotein gene. Virus Res. 2012, 169, 169-174. [CrossRef] [PubMed]

230. Rieder, M.; Brzozka, K.; Pfaller, C.K.; Cox, J.H.; Stitz, L.; Conzelmann, K.-K. Genetic Dissection of Interferon-Antagonistic Functions of Rabies Virus Phosphoprotein: Inhibition of Interferon Regulatory Factor 3 Activation Is Important for Pathogenicity. J. Virol. 2011, 85, 842-852. [CrossRef] [PubMed]

231. Ikeda, Y.; Kubota, D.; Nagasaki, Y. Simple Solid-Phase Synthesis and Biological Properties of Carbohydrate-Oligonucleotide Conjugates Modified at the 3'-Terminus. Bioconjugate Chem. 2010, 21, 1685-1690. [CrossRef] [PubMed]

232. Selvam, C.; Mutisya, D.; Prakash, S.; Ranganna, K.; Thilagavathi, R. Therapeutic potential of chemically modified siRNA: Recent trends. Chem. Biol. Drug Des. 2017, 90, 665-678. [CrossRef]

233. Williams, K.; Christensen, J.; Pedersen, M.T.; Johansen, J.V.; Cloos, P.A.C.; Rappsilber, J.; Helin, K. TET1 and hydroxymethylcytosine in transcription and DNA methylation fidelity. Nature 2011, 473, 343-348. [CrossRef] 
234. Posadas, I.; Guerra, F.J.; Ceña, V. Nonviral vectors for the delivery of small interfering RNAs to the CNS. Nanomedicine 2010, 5, 1219-1236. [CrossRef]

235. Nath, A.; Tyler, K.L. Novel approaches and challenges to treatment of central nervous system viral infections. Ann. Neurol. 2013, 74, 412-422. [CrossRef]

236. Khvorova, A.; Reynolds, A.; Jayasena, S.D. Functional siRNAs and miRNAs Exhibit Strand Bias. Cell 2003, 115, 209-216. [CrossRef]

237. Appling, D.R. Compartmentation of folate-mediated one-carbon metabolism in eukaryotes. FASEB J. 1991, 5, 2645-2651. [CrossRef]

238. Qiu, A.; Jansen, M.; Sakaris, A.; Min, S.H.; Chattopadhyay, S.; Tsai, E.; Sandoval, C.; Zhao, R.; Akabas, M.H.; Goldman, I.D. Identification of an Intestinal Folate Transporter and the Molecular Basis for Hereditary Folate Malabsorption. Cell 2006, 127, 917-928. [CrossRef]

239. Matherly, L.H.; Hou, Z. Structure and Function of the Reduced Folate Carrier. Vitam. Horm. 2008, 79, $145-184$.

240. Antony, A.C. Folate Receptors. Annu. Rev. Nutr. 1996, 16, 501-521. [CrossRef]

241. Salazar, M.D.A.; Ratnam, M. The folate receptor: What does it promise in tissue-targeted therapeutics? Cancer Metastasis Rev. 2007, 26, 141-152. [CrossRef] [PubMed]

242. Low, P.S.; Henne, W.A.; Doorneweerd, D.D. Discovery and Development of Folic-Acid-Based Receptor Targeting for Imaging and Therapy of Cancer and Inflammatory Diseases. Acc. Chem. Res. 2008, 41, 120-129. [CrossRef] [PubMed]

243. Toffoli, G.; Cernigoi, C.; Russo, A.; Gallo, A.; Bagnoli, M.; Boiocchi, M. Overexpression of folate binding protein in ovarian cancers. Int. J. Cancer 1997, 74, 193-198. [CrossRef]

244. Dohmen, C.; Fröhlich, T.; Lächelt, U.; Röhl, I.; Vornlocher, H.-P.; Hadwiger, P.; Wagner, E. Defined Folate-PEG-siRNA Conjugates for Receptor-specific Gene Silencing. Mol. Ther. Nucleic Acids 2012, 1, e7. [CrossRef]

245. Bueno, R.; Appasani, K.; Mercer, H.; Lester, S.; Sugarbaker, D. The $\alpha$ folate receptor is highly activated in malignant pleural mesothelioma. J. Thorac. Cardiovasc. Surg. 2001, 121, 225-233. [CrossRef]

246. Boogerd, L.S.F.; Boonstra, M.C.; Beck, A.-J.; Charehbili, A.; Hoogstins, C.E.S.; Prevoo, H.A.J.M.; Singhal, S.; Low, P.S.; van de Velde, C.J.H.; Vahrmeijer, A.L. Concordance of folate receptor- $\alpha$ expression between biopsy, primary tumor and metastasis in breast cancer and lung cancer patients. Oncotarget 2016, 7, 17442-17454. [CrossRef]

247. Liang, X.; Fan, J.; Zhao, Y.; Cheng, M.; Wang, X.; Jin, R.; Sun, T. A targeted drug delivery system based on folic acid-functionalized upconversion luminescent nanoparticles. J. Biomater. Appl. 2017, 31, 1247-1256. [CrossRef]

248. Moghimipour, E.; Rezaei, M.; Ramezani, Z.; Kouchak, M.; Amini, M.; Angali, K.A.; Dorkoosh, F.A.; Handali, S. Folic acid-modified liposomal drug delivery strategy for tumor targeting of 5-fluorouracil. Eur. J. Pharm. Sci. 2018, 114, 166-174. [CrossRef]

249. Lu, J.Y.; Lowe, D.A.; Kennedy, M.D.; Low, P.S. Folate-Targeted Enzyme Prodrug Cancer Therapy Utilizing Penicillin-V Amidase and a Doxorubicin Prodrug. J. Drug Targeting 1999, 7, 43-53. [CrossRef] [PubMed]

250. Antony, A. The biological chemistry of folate receptors. Blood 1992, 79, 2807-2820. [CrossRef] [PubMed]

251. Matherly, L.H.; Goldman, I.D. Membrane Transport of Folates. Vitam. Horm. 2003, 66, 403-456. [PubMed]

252. Nelson-Rees, W.; Flandermeyer, R. HeLa cultures defined. Science 1976, 191, 96-98. [CrossRef]

253. Gartler, S.M. Apparent HeLa Cell Contamination of Human Heteroploid Cell Lines. Nature 1968, $217,750-751$. [CrossRef]

254. Capes-Davis, A.; Theodosopoulos, G.; Atkin, I.; Drexler, H.G.; Kohara, A.; MacLeod, R.A.F.; Masters, J.R.; Nakamura, Y.; Reid, Y.A.; Reddel, R.R.; et al. Check your cultures! A list of cross-contaminated or misidentified cell lines. Int. J. Cancer 2010, 127, 1-8. [CrossRef]

255. Schaffert, D.; Troiber, C.; Salcher, E.E.; Fröhlich, T.; Martin, I.; Badgujar, N.; Dohmen, C.; Edinger, D.; Kläger, R.; Maiwald, G.; et al. Solid-Phase Synthesis of Sequence-Defined T-, i-, and U-Shape Polymers for pDNA and siRNA Delivery. Angew. Chem. Int. Ed. 2011, 50, 8986-8989. [CrossRef]

256. Akinc, A.; Thomas, M.; Klibanov, A.M.; Langer, R. Exploring polyethylenimine-mediated DNA transfection and the proton sponge hypothesis. J. Gene Med. 2005, 7, 657-663. [CrossRef]

257. Akar, U.; Chaves-Reyez, A.; Barria, M.; Tari, A.; Sanguino, A.; Kondo, Y.; Kondo, S.; Arun, B.; Lopez-Berestein, G.; Ozpolat, B. Silencing of Bcl-2 expression by small interfering RNA induces autophagic cell death in MCF-7 breast cancer cells. Autophagy 2008, 4, 669-679. [CrossRef] 
258. Um, H.-D. Bcl-2 family proteins as regulators of cancer cell invasion and metastasis: A review focusing on mitochondrial respiration and reactive oxygen species. Oncotarget 2016, 7, 5193-5203. [CrossRef]

259. Weiner, D.M.; Goodman, M.W.; Colpitts, T.M.; Feddock, M.A.; Duggento, K.L.; Nash, N.R.; Levey, A.I.; Brann, M.R. Functional Screening of Drug Target Genes. Am. J. Pharmacogenomics 2004, 4, 119-128. [CrossRef]

260. Scarr, E. Muscarinic Receptors: Their Roles in Disorders of the Central Nervous System and Potential as Therapeutic Targets. CNS Neurosci. Ther. 2012, 18, 369-379. [CrossRef] [PubMed]

261. Gosens, R.; Zaagsma, J.; Meurs, H.; Halayko, A.J. Muscarinic receptor signaling in the pathophysiology of asthma and COPD. Respir. Res. 2006, 7, 73. [CrossRef] [PubMed]

262. Pauley, K.M.; Gauna, A.E.; Grichtchenko, I.I.; Chan, E.K.L.; Cha, S. A secretagogue-small interfering RNA conjugate confers resistance to cytotoxicity in a cell model of Sjögren's syndrome. Arthritis Rheum. 2011, 63, 3116-3125. [CrossRef] [PubMed]

263. Brito-Zerón, P.; Baldini, C.; Bootsma, H.; Bowman, S.J.; Jonsson, R.; Mariette, X.; Sivils, K.; Theander, E.; Tzioufas, A.; Ramos-Casals, M. Sjögren syndrome. Nat. Rev. Dis. Prim. 2016, 2, 16047. [CrossRef]

264. Vivino, F.B. The treatment of Sjögren's syndrome patients with Pilocarpine-tablets. Scand. J. Rheumatol. 2001, 30, 1-13. [CrossRef]

265. Ramos-Casals, M.; Brito-Zerón, P.; Sisó-Almirall, A.; Bosch, X.; Tzioufas, A.G. Topical and systemic medications for the treatment of primary Sjögren's syndrome. Nat. Rev. Rheumatol. 2012, 8, 399-411. [CrossRef]

266. Hansen, A.; Dörner, T. Aktuelle therapeutische Optionen bei Sjögren-Syndrom. Z. Rheumatol. 2010, 69, $19-24$. [CrossRef]

267. Stefanski, A.-L.; Tomiak, C.; Pleyer, U.; Dietrich, T.; Burmester, G.R.; Dörner, T. The Diagnosis and Treatment of Sjögren's Syndrome. Dtsch. Aerzteblatt Online 2017, 114, 354-361. [CrossRef]

268. Roescher, N.; Tak, P.; Illei, G. Cytokines in Sjögren's syndrome. Oral Dis. 2009, 15, 519-526. [CrossRef]

269. Roescher, N.; Tak, P.P.; Illei, G.G. Cytokines in Sjögren's syndrome: Potential therapeutic targets. Ann. Rheum. Dis. 2010, 69, 945-948. [CrossRef] [PubMed]

270. Nagy, K.; Szlávik, V.; Rácz, G.; Óvári, G.; Vág, J.; Varga, G. Human submandibular gland (HSG) cell line as a model for studying salivary gland Ca 2+ signalling mechanisms. Acta Physiol. Hung. 2007, 94, 301-313. [CrossRef] [PubMed]

271. Bang, E.-K.; Jeon, E.M.; Kim, W.; Lee, K.-H.; Kim, K.-T.; Kim, B.H. Tissue specific delivery of estrone-conjugated siRNAs. Mol. BioSyst. 2013, 9, 974-977. [CrossRef] [PubMed]

272. Klagsbrun, M.; D'Amore, P.A. Vascular endothelial growth factor and its receptors. Cytokine Growth Factor Rev. 1996, 7, 259-270. [CrossRef]

273. Tammela, T.; Enholm, B.; Alitalo, K.; Paavonen, K. The biology of vascular endothelial growth factors. Cardiovasc. Res. 2005, 65, 550-563. [CrossRef]

274. Carmeliet, P. VEGF as a Key Mediator of Angiogenesis in Cancer. Oncology 2005, 69, 4-10. [CrossRef]

275. Goel, H.L.; Mercurio, A.M. VEGF targets the tumour cell. Nat. Rev. Cancer 2013, 13, 871-882. [CrossRef]

276. Zhao, L.; Yang, Z.; Liu, Y.; Ying, H.; Zhang, H.; Xue, Y. Vascular Endothelial Growth Factor Increases Permeability of the Blood-Tumor Barrier via Caveolae-Mediated Transcellular Pathway. J. Mol. Neurosci. 2011, 44, 122-129. [CrossRef]

277. Saharinen, P.; Eklund, L.; Pulkki, K.; Bono, P.; Alitalo, K. VEGF and angiopoietin signaling in tumor angiogenesis and metastasis. Trends Mol. Med. 2011, 17, 347-362. [CrossRef]

278. Skobe, M.; Hawighorst, T.; Jackson, D.G.; Prevo, R.; Janes, L.; Velasco, P.; Riccardi, L.; Alitalo, K.; Claffey, K.; Detmar, M. Induction of tumor lymphangiogenesis by VEGF-C promotes breast cancer metastasis. Nat. Med. 2001, 7, 192-198. [CrossRef]

279. Thomas, M.P.; Potter, B.V.L. The structural biology of oestrogen metabolism. J. Steroid Biochem. Mol. Biol. 2013, 137, 27-49. [CrossRef] [PubMed]

280. Escande, A.; Pillon, A.; Servant, N.; Cravedi, J.-P.; Larrea, F.; Muhn, P.; Nicolas, J.-C.; Cavaillès, V.; Balaguer, P. Evaluation of ligand selectivity using reporter cell lines stably expressing estrogen receptor alpha or beta. Biochem. Pharmacol. 2006, 71, 1459-1469. [CrossRef] [PubMed]

281. Zhang, Y.; Cristofaro, P.; Silbermann, R.; Pusch, O.; Boden, D.; Konkin, T.; Hovanesian, V.; Monfils, P.R.; Resnick, M.; Moss, S.F.; et al. Engineering Mucosal RNA Interference in Vivo. Mol. Ther. 2006, 14, 336-342. [CrossRef] [PubMed] 
282. Eriksson, M.; Brown, W.T.; Gordon, L.B.; Glynn, M.W.; Singer, J.; Scott, L.; Erdos, M.R.; Robbins, C.M.; Moses, T.Y.; Berglund, P.; et al. Recurrent de novo point mutations in lamin A cause Hutchinson-Gilford progeria syndrome. Nature 2003, 423, 293-298. [CrossRef] [PubMed]

283. Captur, G.; Arbustini, E.; Bonne, G.; Syrris, P.; Mills, K.; Wahbi, K.; Mohiddin, S.A.; McKenna, W.J.; Pettit, S.; Ho, C.Y.; et al. Lamin and the heart. Heart 2018, 104, 468-479. [CrossRef]

284. Meschaninova, M.I.; Novopashina, D.S.; Semikolenova, O.A.; Silnikov, V.N.; Venyaminova, A.G. Novel Convenient Approach to the Solid-Phase Synthesis of Oligonucleotide Conjugates. Molecules 2019, $24,4266$. [CrossRef]

285. Raveendran, R.; Chen, F.; Kent, B.; Stenzel, M.H. Estrone-Decorated Polyion Complex Micelles for Targeted Melittin Delivery to Hormone-Responsive Breast Cancer Cells. Biomacromolecules 2020, 21, 1222-1233. [CrossRef]

286. Grewal, P.K. The Ashwell-Morell Receptor. Methods Enzymol. 2010, 479, 223-241.

287. Spiess, M. The Asialoglycoprotein Receptor: A Model for Endocytic Transport Receptors. Biochemistry 1990, 29, 10009-10018. [CrossRef] [PubMed]

288. Rogers, J.C.; Kornfeld, S. Hepatic uptake of proteins coupled to fetuin glycopeptide. Biochem. Biophys. Res. Commun. 1971, 45, 622-629. [CrossRef]

289. Plank, C.; Zatloukal, K.; Cotten, M.; Mechtler, K.; Wagner, E. Gene transfer into hepatocytes using asialoglycoprotein receptor mediated endocytosis of DNA complexed with an artificial tetra-antennary galactose ligand. Bioconjugate Chem. 1992, 3, 533-539. [CrossRef] [PubMed]

290. Wu, J.; Nantz, M.H.; Zern, M.A. Targeting hepatocytes for drug and gene delivery: Emerging novel approaches and applications. Front. Biosci. 2002, 7, d717-d725. [PubMed]

291. Wu, G.Y.; Wu, C.H. Specific inhibition of hepatitis B viral gene expression in vitro by targeted antisense oligonucleotides. J. Biol. Chem. 1992, 267, 12436-12439. [PubMed]

292. Yu, R.Z.; Graham, M.J.; Post, N.; Riney, S.; Zanardi, T.; Hall, S.; Burkey, J.; Shemesh, C.S.; Prakash, T.P.; Seth, P.P.; et al. Disposition and Pharmacology of a GalNAc3-conjugated ASO Targeting Human Lipoprotein (a) in Mice. Mol. Ther. Nucleic Acids 2016, 5, e317. [CrossRef]

293. D'Souza, A.A.; Devarajan, P. V Asialoglycoprotein receptor mediated hepatocyte targeting-Strategies and applications. J. Control. Release 2015, 203, 126-139. [CrossRef]

294. Huang, X.; Leroux, J.-C.; Castagner, B. Well-Defined Multivalent Ligands for Hepatocytes Targeting via Asialoglycoprotein Receptor. Bioconjugate Chem. 2017, 28, 283-295. [CrossRef]

295. Spinelli, N.; Defrancq, E.; Morvan, F. Glycoclusters on oligonucleotide and PNA scaffolds: Synthesis and applications. Chem. Soc. Rev. 2013, 42, 4557-4573. [CrossRef]

296. Lönnberg, H. Solid-Phase Synthesis of Oligonucleotide Conjugates Useful for Delivery and Targeting of Potential Nucleic Acid Therapeutics. Bioconjugate Chem. 2009, 20, 1065-1094. [CrossRef]

297. Wada, F.; Yamamoto, T.; Ueda, T.; Sawamura, M.; Wada, S.; Harada-Shiba, M.; Obika, S. Cholesterol-GalNAc dual conjugation strategy for reducing renal distribution of antisense oligonucleotides. Nucleic Acid Ther. 2018, 28, 50-57. [CrossRef]

298. Sharma, V.K.; Osborn, M.F.; Hassler, M.R.; Echeverria, D.; Ly, S.; Ulashchik, E.A.; Martynenko-Makaev, Y.V.; Shmanai, V.V.; Zatsepin, T.S.; Khvorova, A.; et al. Novel Cluster and Monomer-Based GalNAc Structures Induce Effective Uptake of siRNAs in Vitro and in Vivo. Bioconjugate Chem. 2018, 29, 2478-2488. [CrossRef]

299. Nair, J.K.; Willoughby, J.L.S.; Chan, A.; Charisse, K.; Alam, M.R.; Wang, Q.; Hoekstra, M.; Kandasamy, P.; Kel'in, A.V.; Milstein, S.; et al. Multivalent N-Acetylgalactosamine-Conjugated siRNA Localizes in Hepatocytes and Elicits Robust RNAi-Mediated Gene Silencing. J. Am. Chem. Soc. 2014, 136, 16958-16961. [CrossRef] [PubMed]

300. Lee, Y.C.; Townsend, R.R.; Hardy, M.R.; Lönngren, J.; Arnarp, J.; Haraldsson, M.; Lönn, H. Binding of synthetic oligosaccharides to the hepatic Gal/GalNAc lectin. Dependence on fine structural features. J. Biol. Chem. 1983, 258, 199-202. [PubMed]

301. Khorev, O.; Stokmaier, D.; Schwardt, O.; Cutting, B.; Ernst, B. Trivalent, Gal/GalNAc-containing ligands designed for the asialoglycoprotein receptor. Bioorg. Med. Chem. 2008, 16, 5216-5231. [CrossRef] [PubMed]

302. Nair, J.K.; Attarwala, H.; Sehgal, A.; Wang, Q.; Aluri, K.; Zhang, X.; Gao, M.; Liu, J.; Indrakanti, R.; Schofield, S.; et al. Impact of enhanced metabolic stability on pharmacokinetics and pharmacodynamics of GalNAc-siRNA conjugates. Nucleic Acids Res. 2017, 45, 10969-10977. [CrossRef] 
303. Severgnini, M.; Sherman, J.; Sehgal, A.; Jayaprakash, N.K.; Aubin, J.; Wang, G.; Zhang, L.; Peng, C.G.; Yucius, K.; Butler, J.; et al. A rapid two-step method for isolation of functional primary mouse hepatocytes: Cell characterization and asialoglycoprotein receptor based assay development. Cytotechnology 2012, 64, 187-195. [CrossRef]

304. Ando, Y.; Ueda, M. Novel methods for detecting amyloidogenic proteins in transthyretin related amyloidosis. Front. Biosci. 2008, 5548-5558. [CrossRef]

305. Garber, K. Alnylam's RNAi therapy targets amyloid disease. Nat. Biotechnol. 2015, 33, 577. [CrossRef]

306. Andrade, C. A peculiar form of peripheral neuropathy. Brain 1952, 75, 408-427. [CrossRef]

307. Kapoor, M.; Rossor, A.M.; Laura, M.; Reilly, M.M. Clinical Presentation, Diagnosis and Treatment of TTR Amyloidosis. J. Neuromuscul. Dis. 2019, 6, 189-199. [CrossRef]

308. Ruberg, F.L.; Berk, J.L. Transthyretin (TTR) Cardiac Amyloidosis. Circulation 2012, 126, 1286-1300. [CrossRef]

309. Adams, D.; Cauquil, C.; Labeyrie, C. Familial amyloid polyneuropathy. Curr. Opin. Neurol. 2017, 30, 481-489. [CrossRef] [PubMed]

310. Coelho, T.; Adams, D.; Silva, A.; Lozeron, P.; Hawkins, P.N.; Mant, T.; Perez, J.; Chiesa, J.; Warrington, S.; Tranter, E.; et al. Safety and Efficacy of RNAi Therapy for Transthyretin Amyloidosis. N. Engl. J. Med. 2013, 369, 819-829. [CrossRef] [PubMed]

311. Sutherland, J.E.; Hettinger, J.L.; Chan, A.; Gilbert, J.; Warner, G.L.; Davis, W.P. Nonclinical Safety Profile of Revusiran, a 1st-Generation GalNAc-siRNA Conjugate for Treatment of Hereditary Transthyretin-Mediated Amyloidosis. Nucleic Acid Ther. 2020, 30, 33-49. [CrossRef] [PubMed]

312. Judge, D.P.; Kristen, A.V.; Grogan, M.; Maurer, M.S.; Falk, R.H.; Hanna, M.; Gillmore, J.; Garg, P.; Vaishnaw, A.K.; Harrop, J.; et al. Phase 3 Multicenter Study of Revusiran in Patients with Hereditary Transthyretin-Mediated (hATTR) Amyloidosis with Cardiomyopathy (ENDEAVOUR). Cardiovasc. Drugs Ther. 2020, 34, 357-370. [CrossRef] [PubMed]

313. Huang, Y. Preclinical and Clinical Advances of GalNAc-Decorated Nucleic Acid Therapeutics. Mol. Ther. Nucleic Acids 2017, 6, 116-132. [CrossRef]

314. Naoumov, N.V. Cyclophilin inhibition as potential therapy for liver diseases. J. Hepatol. 2014, 61, $1166-1174$. [CrossRef]

315. Watashi, K.; Ishii, N.; Hijikata, M.; Inoue, D.; Murata, T.; Miyanari, Y.; Shimotohno, K. Cyclophilin B Is a Functional Regulator of Hepatitis C Virus RNA Polymerase. Mol. Cell 2005, 19, 111-122. [CrossRef]

316. Liu, Z.; Yang, F.; Robotham, J.M.; Tang, H. Critical Role of Cyclophilin A and Its Prolyl-Peptidyl Isomerase Activity in the Structure and Function of the Hepatitis C Virus Replication Complex. J. Virol. 2009, 83, 6554-6565. [CrossRef]

317. Kaul, A.; Stauffer, S.; Berger, C.; Pertel, T.; Schmitt, J.; Kallis, S.; Zayas Lopez, M.; Lohmann, V.; Luban, J.; Bartenschlager, R. Essential Role of Cyclophilin A for Hepatitis C Virus Replication and Virus Production and Possible Link to Polyprotein Cleavage Kinetics. PLoS Pathog. 2009, 5, e1000546. [CrossRef]

318. Kinberger, G.A.; Prakash, T.P.; Yu, J.; Vasquez, G.; Low, A.; Chappell, A.; Schmidt, K.; Murray, H.M.; Gaus, H.; Swayze, E.E.; et al. Conjugation of mono and di-GalNAc sugars enhances the potency of antisense oligonucleotides via ASGR mediated delivery to hepatocytes. Bioorg. Med. Chem. Lett. 2016, 26, 3690-3693. [CrossRef] [PubMed]

319. Schmidt, K.; Prakash, T.P.; Donner, A.J.; Kinberger, G.A.; Gaus, H.J.; Low, A.; Østergaard, M.E.; Bell, M.; Swayze, E.E.; Seth, P.P. Characterizing the effect of GalNAc and phosphorothioate backbone on binding of antisense oligonucleotides to the asialoglycoprotein receptor. Nucleic Acids Res. 2017, 45, 2294-2306. [CrossRef] [PubMed]

320. Westerlind, U.; Westman, J.; Törnquist, E.; Smith, C.I.E.; Oscarson, S.; Lahmann, M.; Norberg, T. Ligands of the asialoglycoprotein receptor for targeted gene delivery, part 1: Synthesis of and binding studies with biotinylated cluster glycosides containing N-acetylgalactosamine. Glycoconjugate J. 2004, 21, 227-241. [CrossRef]

321. Pharmaceuticals, A. The Study of an Investigational Drug, Revusiran (ALN-TTRSC), for the Treatment of Transthyretin (TTR)-Mediated Amyloidosis in Patients Whose Disease Has Continued to Worsen Following Liver Transplant. Available online: https://clinicaltrials.gov/ct2/show/NCT02595983 (accessed on 12 May 2020).

322. Engelhardt, J.A. Comparative Renal Toxicopathology of Antisense Oligonucleotides. Nucleic Acid Ther. 2016, 26, 199-209. [CrossRef] [PubMed] 
323. van Meer, L.; Moerland, M.; van Dongen, M.; Goulouze, B.; de Kam, M.; Klaassen, E.; Cohen, A.; Burggraaf, J. Renal Effects of Antisense-Mediated Inhibition of SGLT2. J. Pharmacol. Exp. Ther. 2016, 359, 280-289. [CrossRef] [PubMed]

324. van Poelgeest, E.P.; Swart, R.M.; Betjes, M.G.H.; Moerland, M.; Weening, J.J.; Tessier, Y.; Hodges, M.R.; Levin, A.A.; Burggraaf, J. Acute Kidney Injury During Therapy With an Antisense Oligonucleotide Directed Against PCSK9. Am. J. Kidney Dis. 2013, 62, 796-800. [CrossRef] [PubMed]

325. Bijsterbosch, M.K. Modulation of plasma protein binding and in vivo liver cell uptake of phosphorothioate oligodeoxynucleotides by cholesterol conjugation. Nucleic Acids Res. 2000, 28, 2717-2725. [CrossRef] [PubMed]

326. Bijsterbosch, M.K.; Manoharan, M.; Dorland, R.; van Veghel, R.; Biessen, E.A.L.; van Berkel, T.J.C. bis-Cholesteryl-Conjugated Phosphorothioate Oligodeoxynucleotides Are Highly Selectively Taken Up by the Liver. J. Pharmacol. Exp. Ther. 2002, 302, 619-626. [CrossRef]

327. Wolfrum, C.; Shi, S.; Jayaprakash, K.N.; Jayaraman, M.; Wang, G.; Pandey, R.K.; Rajeev, K.G.; Nakayama, T.; Charrise, K.; Ndungo, E.M.; et al. Mechanisms and optimization of in vivo delivery of lipophilic siRNAs. Nat. Biotechnol. 2007, 25, 1149-1157. [CrossRef]

328. Watanabe, A.; Nakajima, M.; Kasuya, T.; Onishi, R.; Kitade, N.; Mayumi, K.; Ikehara, T.; Kugimiya, A. Comparative Characterization of Hepatic Distribution and mRNA Reduction of Antisense Oligonucleotides Conjugated with Triantennary N-Acetyl Galactosamine and Lipophilic Ligands Targeting Apolipoprotein B. J. Pharmacol. Exp. Ther. 2016, 357, 320-330. [CrossRef]

329. Straarup, E.M.; Fisker, N.; Hedtjärn, M.; Lindholm, M.W.; Rosenbohm, C.; Aarup, V.; Hansen, H.F.; Ørum, H.; Hansen, J.B.R.; Koch, T. Short locked nucleic acid antisense oligonucleotides potently reduce apolipoprotein B mRNA and serum cholesterol in mice and non-human primates. Nucleic Acids Res. 2010, 38, 7100-7111. [CrossRef]

330. Yamamoto, T.; Wada, F.; Harada-Shiba, M. Development of Antisense Drugs for Dyslipidemia. J. Atheroscler. Thromb. 2016, 23, 1011-1025. [CrossRef] [PubMed]

331. Yamamoto, T.; Sawamura, M.; Wada, F.; Harada-Shiba, M.; Obika, S. Serial incorporation of a monovalent GalNAc phosphoramidite unit into hepatocyte-targeting antisense oligonucleotides. Bioorg. Med. Chem. 2016, 24, 26-32. [CrossRef] [PubMed]

332. Wada, S.; Yasuhara, H.; Wada, F.; Sawamura, M.; Waki, R.; Yamamoto, T.; Harada-Shiba, M.; Obika, S. Evaluation of the effects of chemically different linkers on hepatic accumulations, cell tropism and gene silencing ability of cholesterol-conjugated antisense oligonucleotides. J. Control. Release 2016, 226, 57-65. [CrossRef]

333. Subramanian, R.R.; Wysk, M.A.; Ogilvie, K.M.; Bhat, A.; Kuang, B.; Rockel, T.D.; Weber, M.; Uhlmann, E.; Krieg, A.M. Enhancing antisense efficacy with multimers and multi-targeting oligonucleotides (MTOs) using cleavable linkers. Nucleic Acids Res. 2015, 43, 9123-9132. [CrossRef] [PubMed]

334. Raouane, M.; Desmaële, D.; Urbinati, G.; Massaad-Massade, L.; Couvreur, P. Lipid Conjugated Oligonucleotides: A Useful Strategy for Delivery. Bioconjugate Chem. 2012, 23, 1091-1104. [CrossRef] [PubMed]

335. Allart, B.; Khan, K.; Rosemeyer, H.; Schepers, G.; Hendrix, C.; Rothenbacher, K.; Seela, F.; Van Aerschot, A.; Herdewijn, P. D-Altritol Nucleic Acids (ANA): Hybridisation Properties, Stability, and Initial Structural Analysis. Chem. Eur. J. 1999, 5, 2424-2431. [CrossRef]

336. Fisher, M.; Abramov, M.; Van Aerschot, A.; Xu, D.; Juliano, R.L.; Herdewijn, P. Inhibition of MDR1 expression with altritol-modified siRNAs. Nucleic Acids Res. 2007, 35, 1064-1074. [CrossRef]

337. Schirle, N.T.; MacRae, I.J. The Crystal Structure of Human Argonaute2. Science 2012, 336, $1037-1040$. [CrossRef]

338. Wang, Y.; Juranek, S.; Li, H.; Sheng, G.; Wardle, G.S.; Tuschl, T.; Patel, D.J. Nucleation, propagation and cleavage of target RNAs in Ago silencing complexes. Nature 2009, 461, 754-761. [CrossRef]

339. Abdelkafi, H.; Michau, A.; Clerget, A.; Buisson, D.-A.; Johannes, L.; Gillet, D.; Barbier, J.; Cintrat, J.-C. Synthesis, Chiral Separation, Absolute Configuration Assignment, and Biological Activity of Enantiomers of Retro-1 as Potent Inhibitors of Shiga Toxin. ChemMedChem 2015, 10, 1153-1156. [CrossRef]

340. Barbier, J.; Bouclier, C.; Johannes, L.; Gillet, D. Inhibitors of the Cellular Trafficking of Ricin. Toxins 2012, 4, 15-27. [CrossRef] 
341. Johannes, L.; Lucchino, M. Current Challenges in Delivery and Cytosolic Translocation of Therapeutic RNAs. Nucleic Acid Ther. 2018, 28, 178-193. [CrossRef]

342. Yang, B.; Ming, X.; Cao, C.; Laing, B.; Yuan, A.; Porter, M.A.; Hull-Ryde, E.A.; Maddry, J.; Suto, M.; Janzen, W.P.; et al. High-throughput screening identifies small molecules that enhance the pharmacological effects of oligonucleotides. Nucleic Acids Res. 2015, 43, 1987-1996. [CrossRef] [PubMed]

343. Ming, X.; Carver, K.; Fisher, M.; Noel, R.; Cintrat, J.C.; Gillet, D.; Barbier, J.; Cao, C.; Bauman, J.; Juliano, R.L. The small molecule Retro-1 enhances the pharmacological actions of antisense and splice switching oligonucleotides. Nucleic Acids Res. 2013, 41, 3673-3687. [CrossRef] [PubMed]

344. Juliano, R.L.; Wang, L.; Tavares, F.; Brown, E.G.; James, L.; Ariyarathna, Y.; Ming, X.; Mao, C.; Suto, M. Structure-activity relationships and cellular mechanism of action of small molecules that enhance the delivery of oligonucleotides. Nucleic Acids Res. 2018, 46, 1601-1613. [CrossRef]

345. Agramunt, J.; Pedroso, E.; Kreda, S.; Juliano, R.; Grandas, A. Retro-1-Oligonucleotide Conjugates. Synthesis and Biological Evaluation. Molecules 2019, 24, 579. [CrossRef] [PubMed]

346. Allen, J.; Najjar, K.; Erazo-Oliveras, A.; Kondow-McConaghy, H.M.; Brock, D.J.; Graham, K.; Hager, E.C.; Marschall, A.L.J.; Dübel, S.; Juliano, R.L.; et al. Cytosolic Delivery of Macromolecules in Live Human Cells Using the Combined Endosomal Escape Activities of a Small Molecule and Cell Penetrating Peptides. ACS Chem. Biol. 2019, 14, 2641-2651. [CrossRef] [PubMed]

347. Osborn, M.F.; Khvorova, A. Improving siRNA Delivery In Vivo Through Lipid Conjugation. Nucleic Acid Ther. 2018, 28, 128-136. [CrossRef] [PubMed]

348. Wang, S.; Allen, N.; Prakash, T.P.; Liang, X.; Crooke, S.T. Lipid Conjugates Enhance Endosomal Release of Antisense Oligonucleotides Into Cells. Nucleic Acid Ther. 2019, 29, 245-255. [CrossRef]

349. Liscum, L.; Underwood, K.W. Intracellular Cholesterol Transport and Compartmentation. J. Biol. Chem. 1995, 270, 15443-15446. [CrossRef]

350. Rader, D.J.; Alexander, E.T.; Weibel, G.L.; Billheimer, J.; Rothblat, G.H. The role of reverse cholesterol transport in animals and humans and relationship to atherosclerosis. J. Lipid Res. 2009, 50, S189-S194. [CrossRef] [PubMed]

351. Bijsterbosch, M.K.; Manoharan, M.; Dorland, R.; Waarlo, I.H.E.; Biessen, E.A.L.; van Berkel, T.J.C. Delivery of cholesteryl-conjugated phosphorothioate oligodeoxynucleotides to Kupffer cells by lactosylated low-density lipoprotein. Biochem. Pharmacol. 2001, 62, 627-633. [CrossRef]

352. Grijalvo, S.; Aviñó, A.; Eritja, R. Oligonucleotide delivery: A patent review (2010-2013). Expert Opin. Ther. Pat. 2014, 24, 801-819. [CrossRef] [PubMed]

353. Osborn, M.F.; Coles, A.H.; Biscans, A.; Haraszti, R.A.; Roux, L.; Davis, S.; Ly, S.; Echeverria, D.; Hassler, M.R.; Godinho, B.M.D.C.; et al. Hydrophobicity drives the systemic distribution of lipid-conjugated siRNAs via lipid transport pathways. Nucleic Acids Res. 2019, 47, 1070-1081. [CrossRef]

354. Nishina, K.; Piao, W.; Yoshida-Tanaka, K.; Sujino, Y.; Nishina, T.; Yamamoto, T.; Nitta, K.; Yoshioka, K.; Kuwahara, H.; Yasuhara, H.; et al. DNA/RNA heteroduplex oligonucleotide for highly efficient gene silencing. Nat. Commun. 2015, 6, 7969. [CrossRef]

355. Blumenthal, R.; Clague, M.J.; Durell, S.R.; Epand, R.M. Membrane Fusion. Chem. Rev. 2003, 103, 53-70. [CrossRef]

356. Wickner, W.; Schekman, R. Membrane fusion. Nat. Struct. Mol. Biol. 2008, 15, 658-664. [CrossRef]

357. Goldstein, J.L.; Brown, M.S.; Anderson, R.G.W.; Russell, D.W.; Schneider, W.J. Receptor-Mediated Endocytosis: Concepts Emerging from the LDL Receptor System. Annu. Rev. Cell Biol. 1985, 1, 1-39. [CrossRef]

358. Maurer, M.E.; Cooper, J.A. The adaptor protein Dab2 sorts LDL receptors into coated pits independently of AP-2 and ARH. J. Cell Sci. 2006, 119, 4235-4246. [CrossRef]

359. Angers, C.G.; Merz, A.J. New links between vesicle coats and Rab-mediated vesicle targeting. Semin. Cell Dev. Biol. 2011, 22, 18-26. [CrossRef]

360. Weinreb, G.; Lentz, B.R. Analysis of Membrane Fusion as a Two-State Sequential Process: Evaluation of the Stalk Model. Biophys. J. 2007, 92, 4012-4029. [CrossRef] [PubMed]

361. Patel, H.; Tscheka, C.; Heerklotz, H. Characterizing vesicle leakage by fluorescence lifetime measurements. Soft Matter 2009, 5, 2849-2851. [CrossRef]

362. Chan, Y.-H.M.; van Lengerich, B.; Boxer, S.G. Effects of linker sequences on vesicle fusion mediated by lipid-anchored DNA oligonucleotides. Proc. Natl. Acad. Sci. USA 2009, 106, 979-984. [CrossRef] [PubMed] 
363. Wang, S.; Allen, N.; Liang, X.-H.; Crooke, S.T. Membrane Destabilization Induced by Lipid Species Increases Activity of Phosphorothioate-Antisense Oligonucleotides. Mol. Ther. Nucleic Acids 2018, 13, 686-698. [CrossRef] [PubMed]

364. Miller, C.M.; Wan, W.B.; Seth, P.P.; Harris, E.N. Endosomal Escape of Antisense Oligonucleotides Internalized by Stabilin Receptors Is Regulated by Rab5C and EEA1 During Endosomal Maturation. Nucleic Acid Ther. 2018, 28, 86-96. [CrossRef] [PubMed]

365. Winkler, J. Oligonucleotide conjugates for therapeutic applications. Ther. Deliv. 2013, 4, 791-809. [CrossRef]

366. Benizri, S.; Gissot, A.; Martin, A.; Vialet, B.; Grinstaff, M.W.; Barthélémy, P. Bioconjugated Oligonucleotides: Recent Developments and Therapeutic Applications. Bioconjugate Chem. 2019, 30, 366-383. [CrossRef]

367. Soutschek, J.; Akinc, A.; Bramlage, B.; Charisse, K.; Constien, R.; Donoghue, M.; Elbashir, S.; Gelck, A.; Hadwiger, P.; Harborth, J.; et al. Therapeutic silencing of an endogenous gene by systemic administration of modified siRNAs. Nature 2004, 432, 173-178. [CrossRef]

368. Yang, J.; Chen, C.; Tang, X. Cholesterol-Modified Caged siRNAs for Photoregulating Exogenous and Endogenous Gene Expression. Bioconjugate Chem. 2018, 29, 1010-1015. [CrossRef]

369. Ankenbruck, N.; Courtney, T.; Naro, Y.; Deiters, A. Optochemical Control of Biological Processes in Cells and Animals. Angew. Chem. Int. Ed. 2018, 57, 2768-2798. [CrossRef]

370. Ruble, B.K.; Yeldell, S.B.; Dmochowski, I.J. Caged oligonucleotides for studying biological systems. J. Inorg. Biochem. 2015, 150, 182-188. [CrossRef] [PubMed]

371. Wenter, P.; Fürtig, B.; Hainard, A.; Schwalbe, H.; Pitsch, S. Kinetics of Photoinduced RNA Refolding by Real-Time NMR Spectroscopy. Angew. Chem. Int. Ed. 2005, 44, 2600-2603. [CrossRef] [PubMed]

372. Kröck, L.; Heckel, A. Photoinduced transcription by using temporarily mismatched caged oligonucleotides. Angew. Chem. Int. Ed. 2005, 44, 471-473. [CrossRef] [PubMed]

373. Lusic, H.; Deiters, A. A New Photocaging Group for Aromatic N-Heterocycles. Synthesis 2006, 2147-2150. [CrossRef]

374. Monroe, W.T.; McQuain, M.M.; Chang, M.S.; Alexander, J.S.; Haselton, F.R. Targeting Expression with Light Using Caged DNA. J. Biol. Chem. 1999, 274, 20895-20900. [CrossRef] [PubMed]

375. Conway, J.W.; McLaughlin, C.K.; Castor, K.J.; Sleiman, H. DNA nanostructure serum stability: Greater than the sum of its parts. Chem. Commun. 2013,49, 1172-1174. [CrossRef]

376. Wu, L.; Pei, F.; Zhang, J.; Wu, J.; Feng, M.; Wang, Y.; Jin, H.; Zhang, L.; Tang, X. Synthesis of Site-Specifically Phosphate-Caged siRNAs and Evaluation of Their RNAi Activity and Stability. Chem. Eur. J. 2014, 20, 12114-12122. [CrossRef]

377. Shah, S.; Jain, P.K.; Kala, A.; Karunakaran, D.; Friedman, S.H. Light-activated RNA interference using double-stranded siRNA precursors modified using a remarkable regiospecificity of diazo-based photolabile groups. Nucleic Acids Res. 2009, 37, 4508-4517. [CrossRef]

378. Sawin, K.E.; LeGuellec, K.; Philippe, M.; Mitchison, T.J. Mitotic spindle organization by a plus-end-directed microtubule motor. Nature 1992, 359, 540-543. [CrossRef]

379. Acar, S.; Carlson, D.B.; Budamagunta, M.S.; Yarov-Yarovoy, V.; Correia, J.J.; Niñonuevo, M.R.; Jia, W.; Tao, L.; Leary, J.A.; Voss, J.C.; et al. The bipolar assembly domain of the mitotic motor kinesin-5. Nat. Commun. 2013, 4, 1343. [CrossRef]

380. Bryld, T.; Lomholt, C. Attachment of Cholesterol to Amino-LNA: Synthesis and Hybridization Properties. Nucleosides Nucleotides Nucleic Acids 2007, 26, 1645-1647. [CrossRef] [PubMed]

381. Letsinger, R.L.; Zhang, G.R.; Sun, D.K.; Ikeuchi, T.; Sarin, P.S. Cholesteryl-conjugated oligonucleotides: Synthesis, properties, and activity as inhibitors of replication of human immunodeficiency virus in cell culture. Proc. Natl. Acad. Sci. USA 1989, 86, 6553-6556. [CrossRef] [PubMed]

382. Guzaev, A.; Lönnberg, H. Solid support synthesis of ester linked hydrophobic conjugates of oligonucleotides. Tetrahedron 1999, 55, 9101-9116. [CrossRef]

383. Nishina, K.; Unno, T.; Uno, Y.; Kubodera, T.; Kanouchi, T.; Mizusawa, H.; Yokota, T. Efficient In Vivo Delivery of siRNA to the Liver by Conjugation of $\alpha$-Tocopherol. Mol. Ther. 2008, 16, 734-740. [CrossRef]

384. Uno, Y.; Piao, W.; Miyata, K.; Nishina, K.; Mizusawa, H.; Yokota, T. High-Density Lipoprotein Facilitates In Vivo Delivery of $\alpha$-Tocopherol-Conjugated Short-Interfering RNA to the Brain. Hum. Gene Ther. 2011, 22, 711-719. [CrossRef] 
385. Nishina, T.; Numata, J.; Nishina, K.; Yoshida-Tanaka, K.; Nitta, K.; Piao, W.; Iwata, R.; Ito, S.; Kuwahara, H.; Wada, T.; et al. Chimeric Antisense Oligonucleotide Conjugated to $\alpha$-Tocopherol. Mol. Ther. Nucleic Acids 2015, 4, e220. [CrossRef]

386. Kuwahara, H.; Song, J.; Shimoura, T.; Yoshida-Tanaka, K.; Mizuno, T.; Mochizuki, T.; Zeniya, S.; Li, F.; Nishina, K.; Nagata, T.; et al. Modulation of blood-brain barrier function by a heteroduplex oligonucleotide in vivo. Sci. Rep. 2018, 8, 4377. [CrossRef]

387. Østergaard, M.E.; Jackson, M.; Low, A.; Chappell, A.E.; Lee, R.G.; Peralta, R.Q.; Yu, J.; Kinberger, G.A.; Dan, A.; Carty, R.; et al. Conjugation of hydrophobic moieties enhances potency of antisense oligonucleotides in the muscle of rodents and non-human primates. Nucleic Acids Res. 2019, 47, 6045-6058.

388. Jiang, Q. Natural forms of vitamin E: Metabolism, antioxidant, and anti-inflammatory activities and their role in disease prevention and therapy. Free Radic. Biol. Med. 2014, 72, 76-90. [CrossRef]

389. Constantinou, C.; Papas, A.; Constantinou, A.I. Vitamin E and cancer: An insight into the anticancer activities of vitamin E isomers and analogs. Int. J. Cancer 2008, 123, 739-752. [CrossRef]

390. Pein, H.; Ville, A.; Pace, S.; Temml, V.; Garscha, U.; Raasch, M.; Alsabil, K.; Viault, G.; Dinh, C.-P.; Guilet, D.; et al. Endogenous metabolites of vitamin $\mathrm{E}$ limit inflammation by targeting 5-lipoxygenase. Nat. Commun. 2018, 9, 3834. [CrossRef] [PubMed]

391. Lee, G.; Han, S. The Role of Vitamin E in Immunity. Nutrients 2018, 10, 1614. [CrossRef] [PubMed]

392. Rashid Khan, M.; Ahsan, H.; Siddiqui, S.; Siddiqui, W.A. Tocotrienols have a nephroprotective action against lipid-induced chronic renal dysfunction in rats. Ren. Fail. 2015, 37, 136-143. [CrossRef] [PubMed]

393. Selim, A.; Khalaf, M.M.; Gad, A.M.; Abd El-Raouf, O.M. Evaluation of the possible nephroprotective effects of vitamin $\mathrm{E}$ and rosuvastatin in amikacin-induced renal injury in rats. J. Biochem. Mol. Toxicol. 2017, 31, e21957. [CrossRef]

394. Ahsan, H.; Ahad, A.; Iqbal, J.; Siddiqui, W.A. Pharmacological potential of tocotrienols: A review. Nutr. Metab. 2014, 11, 52. [CrossRef]

395. Saini, R.K.; Keum, Y.-S. Tocopherols and tocotrienols in plants and their products: A review on methods of extraction, chromatographic separation, and detection. Food Res. Int. 2016, 82, 59-70. [CrossRef]

396. Kayden, H.J.; Traber, M.G. Absorption, lipoprotein transport, and regulation of plasma concentrations of vitamin E in humans. J. Lipid Res. 1993, 34, 343-358.

397. Qian, J.; Morley, S.; Wilson, K.; Nava, P.; Atkinson, J.; Manor, D. Intracellular trafficking of vitamin E in hepatocytes: The role of tocopherol transfer protein. J. Lipid Res. 2005, 46, 2072-2082. [CrossRef]

398. Rose, S.D.; Kim, D.-H.; Amarzguioui, M.; Heidel, J.D.; Collingwood, M.A.; Davis, M.E.; Rossi, J.J.; Behlke, M.A. Functional polarity is introduced by Dicer processing of short substrate RNAs. Nucleic Acids Res. 2005, 33, 4140-4156. [CrossRef]

399. Thakker, D.R.; Natt, F.; Husken, D.; Maier, R.; Muller, M.; van der Putten, H.; Hoyer, D.; Cryan, J.F. Neurochemical and behavioral consequences of widespread gene knockdown in the adult mouse brain by using nonviral RNA interference. Proc. Natl. Acad. Sci. USA 2004, 101, 17270-17275. [CrossRef]

400. Senechal, Y.; Kelly, P.H.; Cryan, J.F.; Natt, F.; Dev, K.K. Amyloid precursor protein knockdown by siRNA impairs spontaneous alternation in adult mice. J. Neurochem. 2007, 102, 1928-1940. [CrossRef] [PubMed]

401. Goti, D.; Balazs, Z.; Panzenboeck, U.; Hrzenjak, A.; Reicher, H.; Wagner, E.; Zechner, R.; Malle, E.; Sattler, W. Effects of Lipoprotein Lipase on Uptake and Transcytosis of Low Density Lipoprotein (LDL) and LDL-associated $\alpha$-Tocopherol in a Porcine in Vitro Blood-Brain Barrier Model. J. Biol. Chem. 2002, 277, 28537-28544. [CrossRef] [PubMed]

402. McConlogue, L.; Buttini, M.; Anderson, J.P.; Brigham, E.F.; Chen, K.S.; Freedman, S.B.; Games, D.; Johnson-Wood, K.; Lee, M.; Zeller, M.; et al. Partial Reduction of BACE1 Has Dramatic Effects on Alzheimer Plaque and Synaptic Pathology in APP Transgenic Mice. J. Biol. Chem. 2007, 282, 26326-26334. [CrossRef]

403. Bahn, G.; Park, J.-S.; Yun, U.J.; Lee, Y.J.; Choi, Y.; Park, J.S.; Baek, S.H.; Choi, B.Y.; Cho, Y.S.; Kim, H.K.; et al. NRF2/ARE pathway negatively regulates BACE1 expression and ameliorates cognitive deficits in mouse Alzheimer's models. Proc. Natl. Acad. Sci. USA 2019, 116, 12516-12523. [CrossRef] [PubMed]

404. Murray, S.; Ittig, D.; Koller, E.; Berdeja, A.; Chappell, A.; Prakash, T.P.; Norrbom, M.; Swayze, E.E.; Leumann, C.J.; Seth, P.P. TricycloDNA-modified oligo-2'-deoxyribonucleotides reduce scavenger receptor B1 mRNA in hepatic and extra-hepatic tissues-A comparative study of oligonucleotide length, design and chemistry. Nucleic Acids Res. 2012, 40, 6135-6143. [CrossRef] 
405. Donner, A.J.; Wancewicz, E.V.; Murray, H.M.; Greenlee, S.; Post, N.; Bell, M.; Lima, W.F.; Swayze, E.E.; Seth, P.P. Co-Administration of an Excipient Oligonucleotide Helps Delineate Pathways of Productive and Nonproductive Uptake of Phosphorothioate Antisense Oligonucleotides in the Liver. Nucleic Acid Ther. 2017, 27, 209-220. [CrossRef]

406. Kikuchi, T.; Okamura, T.; Wakizaka, H.; Okada, M.; Odaka, K.; Yui, J.; Tsuji, A.B.; Fukumura, T.; Zhang, M.-R. OAT3-Mediated Extrusion of the 99m Tc-ECD Metabolite in the Mouse Brain. J. Cereb. Blood Flow Metab. 2014, 34, 585-588. [CrossRef]

407. Sweet, D.H.; Miller, D.S.; Pritchard, J.B.; Fujiwara, Y.; Beier, D.R.; Nigam, S.K. Impaired Organic Anion Transport in Kidney and Choroid Plexus of Organic Anion Transporter 3 (Oat3 (Slc22a8)) Knockout Mice. J. Biol. Chem. 2002, 277, 26934-26943. [CrossRef]

408. Yednock, T.A.; Cannon, C.; Fritz, L.C.; Sanchez-Madrid, F.; Steinman, L.; Karin, N. Prevention of experimental autoimmune encephalomyelitis by antibodies against $\alpha 4 \beta 1$ integrin. Nature 1992, 356, 63-66. [CrossRef]

409. Deane, R.; Du Yan, S.; Submamaryan, R.K.; LaRue, B.; Jovanovic, S.; Hogg, E.; Welch, D.; Manness, L.; Lin, C.; $\mathrm{Yu}$, J.; et al. RAGE mediates amyloid- $\beta$ peptide transport across the blood-brain barrier and accumulation in brain. Nat. Med. 2003, 9, 907-913. [CrossRef]

410. Simonen, P.P.; Gylling, H.; Miettinen, T.A. The distribution of squalene and non-cholesterol sterols in lipoproteins in type 2 diabetes. Atherosclerosis 2007, 194, 222-229. [CrossRef] [PubMed]

411. Reddy, L.H.; Couvreur, P. Squalene: A natural triterpene for use in disease management and therapy. Adv. Drug Deliv. Rev. 2009, 61, 1412-1426. [CrossRef] [PubMed]

412. Dobrovolskaia, M.A.; McNeil, S.E. Immunological and hematological toxicities challenging clinical translation of nucleic acid-based therapeutics. Expert Opin. Biol. Ther. 2015, 15, 1023-1048. [CrossRef] [PubMed]

413. Dobrovolskaia, M.A.; McNeil, S.E. Strategy for selecting nanotechnology carriers to overcome immunological and hematological toxicities challenging clinical translation of nucleic acid-based therapeutics. Expert Opin. Drug Deliv. 2015, 12, 1163-1175. [CrossRef]

414. Huang, X.; Brazel, C.S. On the importance and mechanisms of burst release in matrix-controlled drug delivery systems. J. Control. Release 2001, 73, 121-136. [CrossRef]

415. Desmaële, D.; Gref, R.; Couvreur, P. Squalenoylation: A generic platform for nanoparticular drug delivery. J. Control. Release 2012, 161, 609-618. [CrossRef]

416. Sémiramoth, N.; Di Meo, C.; Zouhiri, F.; Saïd-Hassane, F.; Valetti, S.; Gorges, R.; Nicolas, V.; Poupaert, J.H.; Chollet-Martin, S.; Desmaële, D.; et al. Self-Assembled Squalenoylated Penicillin Bioconjugates: An Original Approach for the Treatment of Intracellular Infections. ACS Nano 2012, 6, 3820-3831. [CrossRef]

417. Maksimenko, A.; Dosio, F.; Mougin, J.; Ferrero, A.; Wack, S.; Reddy, L.H.; Weyn, A.-A.; Lepeltier, E.; Bourgaux, C.; Stella, B.; et al. A unique squalenoylated and nonpegylated doxorubicin nanomedicine with systemic long-circulating properties and anticancer activity. Proc. Natl. Acad. Sci. USA 2014, 111, 217-226. [CrossRef]

418. Borrelli, S.; Christodoulou, M.S.; Ficarra, I.; Silvani, A.; Cappelletti, G.; Cartelli, D.; Damia, G.; Ricci, F.; Zucchetti, M.; Dosio, F.; et al. New class of squalene-based releasable nanoassemblies of paclitaxel, podophyllotoxin, camptothecin and epothilone A. Eur. J. Med. Chem. 2014, 85, 179-190. [CrossRef]

419. Cheikh-Ali, Z.; Caron, J.; Cojean, S.; Bories, C.; Couvreur, P.; Loiseau, P.M.; Desmaële, D.; Poupon, E.; Champy, P. “Squalenoylcurcumin” Nanoassemblies as Water-Dispersible Drug Candidates with Antileishmanial Activity. ChemMedChem 2015, 10, 411-418. [CrossRef]

420. Couvreur, P.; Stella, B.; Reddy, L.H.; Hillaireau, H.; Dubernet, C.; Desmaële, D.; Lepêtre-Mouelhi, S.; Rocco, F.; Dereuddre-Bosquet, N.; Clayette, P.; et al. Squalenoyl Nanomedicines as Potential Therapeutics. Nano Lett. 2006, 6, 2544-2548. [CrossRef] [PubMed]

421. Raouane, M.; Desmaele, D.; Gilbert-Sirieix, M.; Gueutin, C.; Zouhiri, F.; Bourgaux, C.; Lepeltier, E.; Gref, R.; Ben Salah, R.; Clayman, G.; et al. Synthesis, Characterization, and in Vivo Delivery of siRNA-Squalene Nanoparticles Targeting Fusion Oncogene in Papillary Thyroid Carcinoma. J. Med. Chem. 2011, 54, 4067-4076. [CrossRef] [PubMed]

422. Gilbert-Sirieix, M.; Ripoche, H.; Malvy, C.; Massaad-Massade, L. Effects of Silencing RET/PTC1 Junction Oncogene in Human Papillary Thyroid Carcinoma Cells. Thyroid 2010, 20, 1053-1065. [CrossRef] [PubMed]

423. Smanik, P.A.; Furminger, T.L.; Mazzaferri, E.L.; Jhiang, S.M. Breakpoint characterization of the ret/PTC oncogene in human papillary thyroid carcinoma. Hum. Mol. Genet. 1995, 4, 2313-2318. [CrossRef] 
424. Santoro, M.; Melillo, R.M.; Fusco, A. RET/PTC activation in papillary thyroid carcinoma: European Journal of Endocrinology Prize Lecture. Eur. J. Endocrinol. 2006, 155, 645-653. [CrossRef]

425. Urbinati, G.; Ali, H.M.; Rousseau, Q.; Chapuis, H.; Desmaële, D.; Couvreur, P.; Massaad-Massade, L. Antineoplastic Effects of siRNA against TMPRSS2-ERG Junction Oncogene in Prostate Cancer. PLoS ONE 2015, 10, e0125277. [CrossRef]

426. Tomlins, S.A. Recurrent Fusion of TMPRSS2 and ETS Transcription Factor Genes in Prostate Cancer. Science 2005, 310, 644-648. [CrossRef]

427. Attard, G.; Swennenhuis, J.F.; Olmos, D.; Reid, A.H.M.; Vickers, E.; A'Hern, R.; Levink, R.; Coumans, F.; Moreira, J.; Riisnaes, R.; et al. Characterization of ERG, AR and PTEN Gene Status in Circulating Tumor Cells from Patients with Castration-Resistant Prostate Cancer. Cancer Res. 2009, 69, 2912-2918. [CrossRef]

428. Ricci, F.; Buzzatti, G.; Rubagotti, A.; Boccardo, F. Safety of antiandrogen therapy for treating prostate cancer. Expert Opin. Drug Saf. 2014, 13, 1483-1499. [CrossRef]

429. Labrie, F. Mechanism of action and pure antiandrogenic properties of flutamide. Cancer 1993, 72, 3816-3827. [CrossRef]

430. Tomlins, S.A.; Laxman, B.; Varambally, S.; Cao, X.; Yu, J.; Helgeson, B.E.; Cao, Q.; Prensner, J.R.; Rubin, M.A.; Shah, R.B.; et al. Role of the TMPRSS2-ERG Gene Fusion in Prostate Cancer. Neoplasia 2008, 10, 177-188. [CrossRef] [PubMed]

431. Paoloni-Giacobino, A.; Chen, H.; Peitsch, M.C.; Rossier, C.; Antonarakis, S.E. Cloning of the TMPRSS2 Gene, Which Encodes a Novel Serine Protease with Transmembrane, LDLRA, and SRCR Domains and Maps to 21q22.3. Genomics 1997, 44, 309-320. [CrossRef] [PubMed]

432. Clark, J.P.; Cooper, C.S. ETS gene fusions in prostate cancer. Nat. Rev. Urol. 2009, 6, 429-439. [CrossRef] [PubMed]

433. Lee, G.M.; Donaldson, L.W.; Pufall, M.A.; Kang, H.-S.; Pot, I.; Graves, B.J.; McIntosh, L.P. The Structural and Dynamic Basis of Ets-1 DNA Binding Autoinhibition. J. Biol. Chem. 2005, 280, 7088-7099. [CrossRef]

434. Mehra, R.; Tomlins, S.A.; Yu, J.; Cao, X.; Wang, L.; Menon, A.; Rubin, M.A.; Pienta, K.J.; Shah, R.B.; Chinnaiyan, A.M. Characterization of TMPRSS2-ETS Gene Aberrations in Androgen-Independent Metastatic Prostate Cancer. Cancer Res. 2008, 68, 3584-3590. [CrossRef]

435. Cai, C.; Wang, H.; Xu, Y.; Chen, S.; Balk, S.P. Reactivation of Androgen Receptor-Regulated TMPRSS2:ERG Gene Expression in Castration-Resistant Prostate Cancer. Cancer Res. 2009, 69, 6027-6032. [CrossRef]

436. Christensen, J.; Litherland, K.; Faller, T.; Van De Kerkhof, E.; Natt, F.; Hunziker, J.; Krauser, J.; Swart, P. Metabolism studies of unformulated internally $\left[{ }^{3} \mathrm{H}\right]$-labeled short interfering RNAs in mice. Drug Metab. Dispos. 2013, 41, 1211-1219. [CrossRef]

437. Ali, H.M.; Urbinati, G.; Chapuis, H.; DesmaEle, D.; Bertrand, J.-R.; Couvreur, P.; Massaad-Massade, L. Effects of siRNA on RET/PTC3 Junction Oncogene in Papillary Thyroid Carcinoma: From Molecular and Cellular Studies to Preclinical Investigations. PLoS ONE 2014, 9, e95964. [CrossRef]

438. Ali,H.M.; Maksimenko, A.; Urbinati, G.; Chapuis, H.; Raouane, M.; Desmaële, D.; Yasuhiro, H.; Harashima, H.; Couvreur, P.; Massaad-Massade, L. Effects of Silencing the RET/PTC1 Oncogene in Papillary Thyroid Carcinoma by siRNA-Squalene Nanoparticles With and Without Fusogenic Companion GALA-Cholesterol. Thyroid 2014, 24, 327-338. [CrossRef]

439. Starke, D.; Lischka, K.; Pagels, P.; Uhlmann, E.; Kramer, W.; Wess, G.; Petzinger, E. Bile acid-oligodeoxynucleotide conjugates: Synthesis and liver excretion in rats. Bioorg. Med. Chem. Lett. 2001, 11, 945-949. [CrossRef]

440. Lehmann, T.J.; Engels, J.W. Synthesis and Properties of Bile Acid Phosphoramidites 5'-Tethered to Antisense Oligodeoxynucleotides against HCV. Bioorg. Med. Chem. 2001, 9, 1827-1835. [CrossRef]

441. González-Carmona, M.A.; Quasdorff, M.; Vogt, A.; Tamke, A.; Yildiz, Y.; Hoffmann, P.; Lehmann, T.; Bartenschlager, R.; Engels, J.W.; Kullak-Ublick, G.A.; et al. Inhibition of hepatitis C virus RNA translation by antisense bile acid conjugated phosphorothioate modified oligodeoxynucleotides (ODN). Antiviral Res. 2013, 97, 49-59. [CrossRef] [PubMed]

442. Imetelstat Sodium in Treating Patients with Primary or Secondary Myelofibrosis-ClinicalTrials.gov. Available online: https://clinicaltrials.gov/ct2/show/NCT01731951 (accessed on 14 April 2020). 
443. Herbert, B.-S.; Gellert, G.C.; Hochreiter, A.; Pongracz, K.; Wright, W.E.; Zielinska, D.; Chin, A.C.; Harley, C.B.; Shay, J.W.; Gryaznov, S.M. Lipid modification of GRN163, an N3' $\rightarrow$ P5' thio-phosphoramidate oligonucleotide, enhances the potency of telomerase inhibition. Oncogene 2005, 24, 5262-5268. [CrossRef] [PubMed]

444. Blasco, M.A. Telomeres and human disease: Ageing, cancer and beyond. Nat. Rev. Genet. 2005, 6, 611-622. [CrossRef]

445. Chen, X.; Tang, W.; Shi, J.B.; Liu, M.M.; Liu, X. Therapeutic strategies for targeting telomerase in cancer. Med. Res. Rev. 2020, 40, 532-585. [CrossRef]

446. Asai, A.; Oshima, Y.; Yamamoto, Y.; Uochi, T.; Kusaka, H.; Akinaga, S.; Yamashita, Y.; Pongracz, K.; Pruzan, R.; Wunder, E.; et al. A novel telomerase template antagonist (GRN163) as a potential anticancer agent. Cancer Res. 2003, 63, 3931-3939.

447. Burchett, K.M.; Yan, Y.; Ouellette, M.M. Telomerase Inhibitor Imetelstat (GRN163L) Limits the Lifespan of Human Pancreatic Cancer Cells. PLoS ONE 2014, 9, e85155. [CrossRef]

448. Aslesh, T.; Maruyama, R.; Yokota, T. Skipping Multiple Exons to Treat DMD—Promises and Challenges. Biomedicines 2018, 6, 1. [CrossRef]

449. Railroading at the FDA. Nat. Biotechnol. 2016, 34, 1078. [CrossRef]

450. Arun, G.; Diermeier, S.; Akerman, M.; Chang, K.-C.; Wilkinson, J.E.; Hearn, S.; Kim, Y.; MacLeod, A.R.; Krainer, A.R.; Norton, L.; et al. Differentiation of mammary tumors and reduction in metastasis upon Malat1 lncRNA loss. Genes Dev. 2016, 30, 34-51. [CrossRef]

451. Karaki, S.; Benizri, S.; Mejías, R.; Baylot, V.; Branger, N.; Nguyen, T.; Vialet, B.; Oumzil, K.; Barthélémy, P.; Rocchi, P. Lipid-oligonucleotide conjugates improve cellular uptake and efficiency of TCTP-antisense in castration-resistant prostate cancer. J. Control. Release 2017, 258, 1-9. [CrossRef] [PubMed]

452. Acunzo, J.; Baylot, V.; So, A.; Rocchi, P. TCTP as therapeutic target in cancers. Cancer Treat. Rev. 2014, 40, 760-769. [CrossRef] [PubMed]

453. Amson, R.; Pece, S.; Lespagnol, A.; Vyas, R.; Mazzarol, G.; Tosoni, D.; Colaluca, I.; Viale, G.; Rodrigues-Ferreira, S.; Wynendaele, J.; et al. Reciprocal repression between P53 and TCTP. Nat. Med. 2012, 18, 91-99. [CrossRef] [PubMed]

454. Du, J.; Yang, P.; Kong, F.; Liu, H. Aberrant expression of translationally controlled tumor protein (TCTP) can lead to radioactive susceptibility and chemosensitivity in lung cancer cells. Oncotarget 2017, 8, 101922-101935. [CrossRef]

455. Baylot, V.; Katsogiannou, M.; Andrieu, C.; Taieb, D.; Acunzo, J.; Giusiano, S.; Fazli, L.; Gleave, M.; Garrido, C.; Rocchi, P. Targeting TCTP as a New Therapeutic Strategy in Castration-resistant Prostate Cancer. Mol. Ther. 2012, 20, 2244-2256. [CrossRef]

456. Betsch, L.; Boltz, V.; Brioudes, F.; Pontier, G.; Girard, V.; Savarin, J.; Wipperman, B.; Chambrier, P.; Tissot, N.; Benhamed, M.; et al. TCTP and CSN4 control cell cycle progression and development by regulating CULLIN1 neddylation in plants and animals. PLoS Genet. 2019, 15, e1007899. [CrossRef] [PubMed]

457. Susini, L.; Besse, S.; Duflaut, D.; Lespagnol, A.; Beekman, C.; Fiucci, G.; Atkinson, A.R.; Busso, D.; Poussin, P.; Marine, J.-C.; et al. TCTP protects from apoptotic cell death by antagonizing bax function. Cell Death Differ. 2008, 15, 1211-1220. [CrossRef]

458. Ling, Y.; Wei, K.; Luo, Y.; Gao, X.; Zhong, S. Dual docetaxel/superparamagnetic iron oxide loaded nanoparticles for both targeting magnetic resonance imaging and cancer therapy. Biomaterials 2011, 32, 7139-7150. [CrossRef]

459. Tannock, I.F.; de Wit, R.; Berry, W.R.; Horti, J.; Pluzanska, A.; Chi, K.N.; Oudard, S.; Théodore, C.; James, N.D.; Turesson, I.; et al. Docetaxel plus Prednisone or Mitoxantrone plus Prednisone for Advanced Prostate Cancer. N. Engl. J. Med. 2004, 351, 1502-1512. [CrossRef]

Publisher's Note: MDPI stays neutral with regard to jurisdictional claims in published maps and institutional affiliations.

(C) 2020 by the authors. Licensee MDPI, Basel, Switzerland. This article is an open access article distributed under the terms and conditions of the Creative Commons Attribution (CC BY) license (http://creativecommons.org/licenses/by/4.0/). 